\title{
A survey of the scleractinian corals at Mermaid, Scott, and Seringapatam Reefs, Western Australia.
}

\author{
David McKinney \\ Australian Institute of Marine Science Email: d.mckinney@aims.gov.au
}

\begin{abstract}
A diverse assemblage of scleractinian species was recorded during a rapid assessment of the shallow water coral taxa of Mermaid, Scott and Seringapatam Reefs. All taxa were predominately widespread Indo-Pacific species that present clear affinities with coral assemblages of Ashmore Reef and the Indonesian provinces to the north. A total of 269 scleractinian species from 57 genera in 14 families were recorded, comprised of 211 species at Mermaid Reef, 224 species at South Scott Reef, 201 species at North Scott, and 159 species at Seringapatam. The study yielded 22 new distribution records for Mermaid Reef, 18 new distribution records for Scott-Seringapatam, one new record for Western Australia (Fungia moluccensis), and one new record for the Rowley-Scott region (Montipora digitata, previously recorded from Ashmore Reef). Multivariate analyses indicated there were distinct communities within and among reefs associated with the reef front, lagoon, and intertidal reef flat habitats.
\end{abstract}

Keywords: Species richness, taxonomy, biogeography, disturbance.

\section{INTRODUCTION}

A considerable body of research has examined the ecology and distribution of the zooxanthellate scleractinia in coastal Western Australia. However, relatively few studies have investigated the coral biodiversity of the emergent shelf-edge atolls located in the oceanic region off the northwest continental mainland. Early taxonomic expeditions by the Western Australian Museum (WA Museum) documented the coral fauna of the Rowley Shoals, Scott Reef, and Seringapatam (Veron, 1986), and Ashmore Reef and Cartier Island (Veron, 1993; Veron and Marsh, 1988), while more recent taxonomic studies by Griffiths (1997) re-examined the corals of Ashmore Reef. Long-term monitoring of the region's coral resources by the Australian Institute of Marine Science (AIMS) including (Heyward et al., 1995, 1997; Heyward et al., 1999; Smith et al., 2004) and several predominately taxonomic-based surveys by Done et al., (1994) and Wolstenholme and Smith (unpublished data), has resulted in a relatively deep understanding of the region's coral fauna and the accumulation of a considerable taxonomic inventory for the region.

The Rowley Shoals, Scott Reef and Seringapatam Reefs are influenced by a common suite of environmental variables, including large tidal regimes, warm sea surface temperatures, exposed aspects, and clear oceanic water inputs.
However, differing geomorphological and physical characteristics between and within the major reef systems have resulted in heterogeneous physical habitats across exposed reef fronts, protected lagoons, and intertidal reef flats. These reef systems have also been impacted by several major disturbance events: in 1998, sustained elevated sea surface temperatures resulted in mass bleaching (Heyward et al., 1999; Smith et al., in review), and in 2004, category five Cyclone Fay resulted in widespread destruction of coral communities (Gilmour and Smith, 2006).

This study presents a preliminary rapid assessment of scleractinian species richness and abundance at Mermaid Reef (Rowley Shoals), South Scott, North Scott, and Seringapatam Reefs. The primary aims of this survey were to assess regional coral biodiversity, provide a quantitative assessment of abundance, execute a repeatable search effort that may afford future comparison between further surveys, and examine the taxonomic and biogeographical relationships of the complex mosaic of coral communities that exist in the region.

\section{METHODS}

Surveys were conducted at a series of stations that were selected using satellite imagery and historical records to maximize habitat diversity and to 


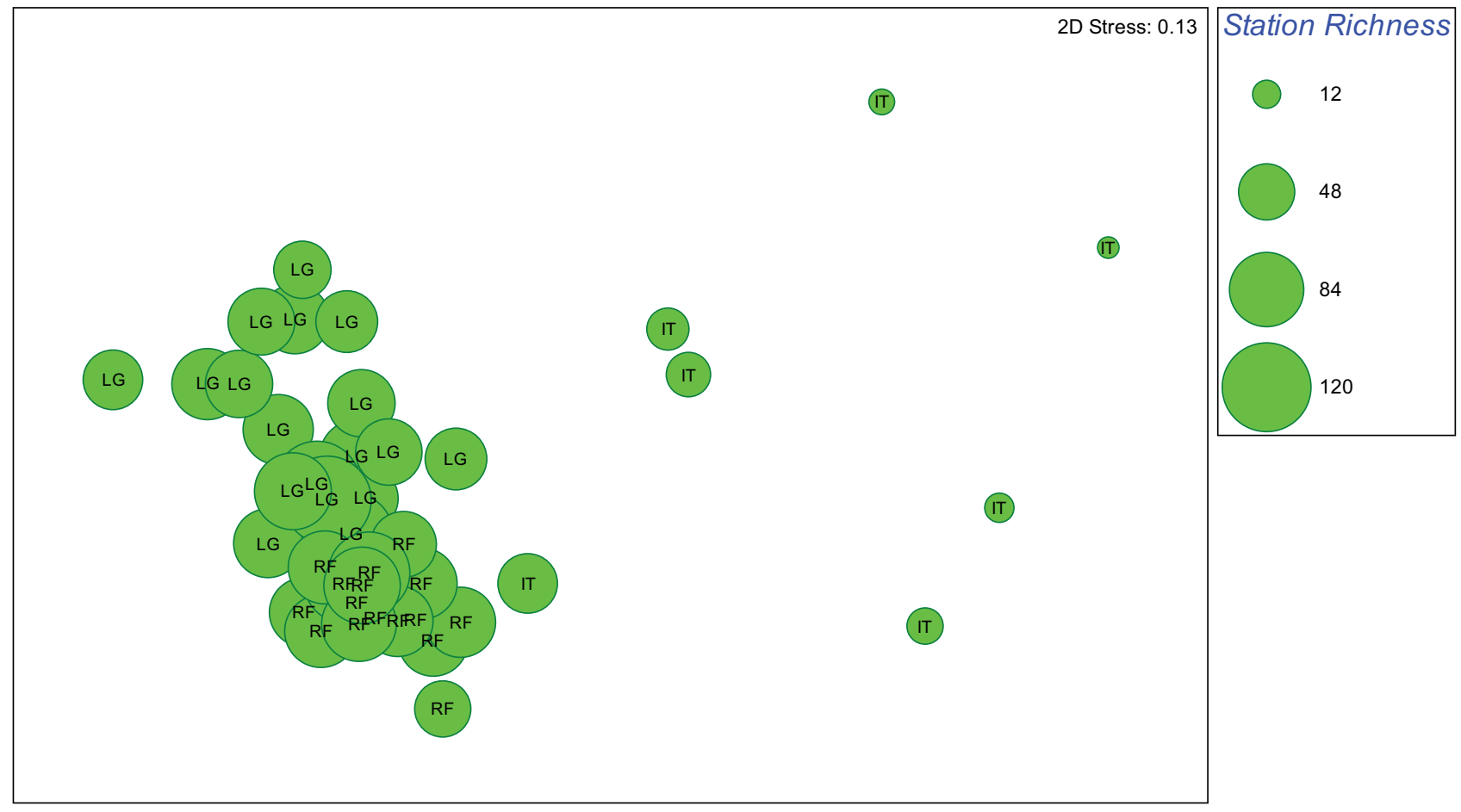

Figure 1 MDS ordination of 41 stations from Mermaid, South Scott, North Scott and Seringapatam, based on untransformed presence/absence and Bray-Curtis similarities. Station richness is superimposed over each station and the major habitat types are indicated: lagoon (LG), reef front (RF), intertidal reef flat (IT).

incorporate previous WA Museum and AIMS study sites. A total of 45 stations were surveyed by scuba, snorkelling and reef walking. A list of stations and habitat descriptions is presented in the Station and Transect Data section of this volume.

Surveys at each station were conducted along two $15 \mathrm{~m} \times 1 \mathrm{~m}$ transects laid over the dominant habitat (typically parallel to the reef contour or reef crest) at approximately $5 \mathrm{~m}$ and $12 \mathrm{~m}$ depth, corrected to mean sea level. Transect depths were chosen to maximize species diversity and abundance by capturing the shallow reef slope between 3-6 m depth and the deeper reef slope at $10-14 \mathrm{~m}$, as reported by Heyward for Scott Reef, (pers. comm.) and DeVantier et al., in other locations (2006). Exceptions to the standard two transect method were stations 10, 13, 27, 40 (no transects were used, but surveyed for biodiversity), stations $29,35,42,44$ (one transect only used, plus 30 minutes additional search time), and stations 10, 13 (repeat survey at same location). Stations 10, 13, 27, 40 were excluded from all analyses due to non-standard search effort. Stations were scored against a series of habitat descriptors (refer Table 4), and a two-tiered survey approach was utilized at each station to assess biodiversity and abundance respectively.

Tier One: The presence of all species encountered along each transect was recorded during a visual survey. Additional search time to a maximum of 10 minutes per station was used to supplement sightings along the transects. Additional searches were conducted haphazardly, adjacent to, and between, transects. Opportunistic sightings, made outside the transect area or during additional search time, were recorded separately as extra sightings.

Station richness (defined as the total number of discrete species recorded at each station) was calculated by aggregating the number of species sighted along the transects, with those recorded during extra time or opportunistically off the transect.

Tier Two: Quantitative estimates of abundance at functional group levels were generated by video transect analysis, with estimates of percentage cover assigned to each group. Refer to, The subtidal habitats of Mermaid Reef (Rowley Shoals), Scott and Seringapatam Reefs, Western Australia. (this volume) for further discussion of these methods and analyses of these data.

Coral taxa on visual surveys were identified in situ to species level, or where identification could not be resolved, a voucher specimen was collected for further taxonomic analysis at WA Museum. Voucher specimens were bleached in calcium hypochlorite, then washed in seawater before being dried and packed for shipping.

Corals were identified using Veron (2000; 2002) and Veron and Stafford-Smith (2002), with the exception of the genus Acropora which follows 


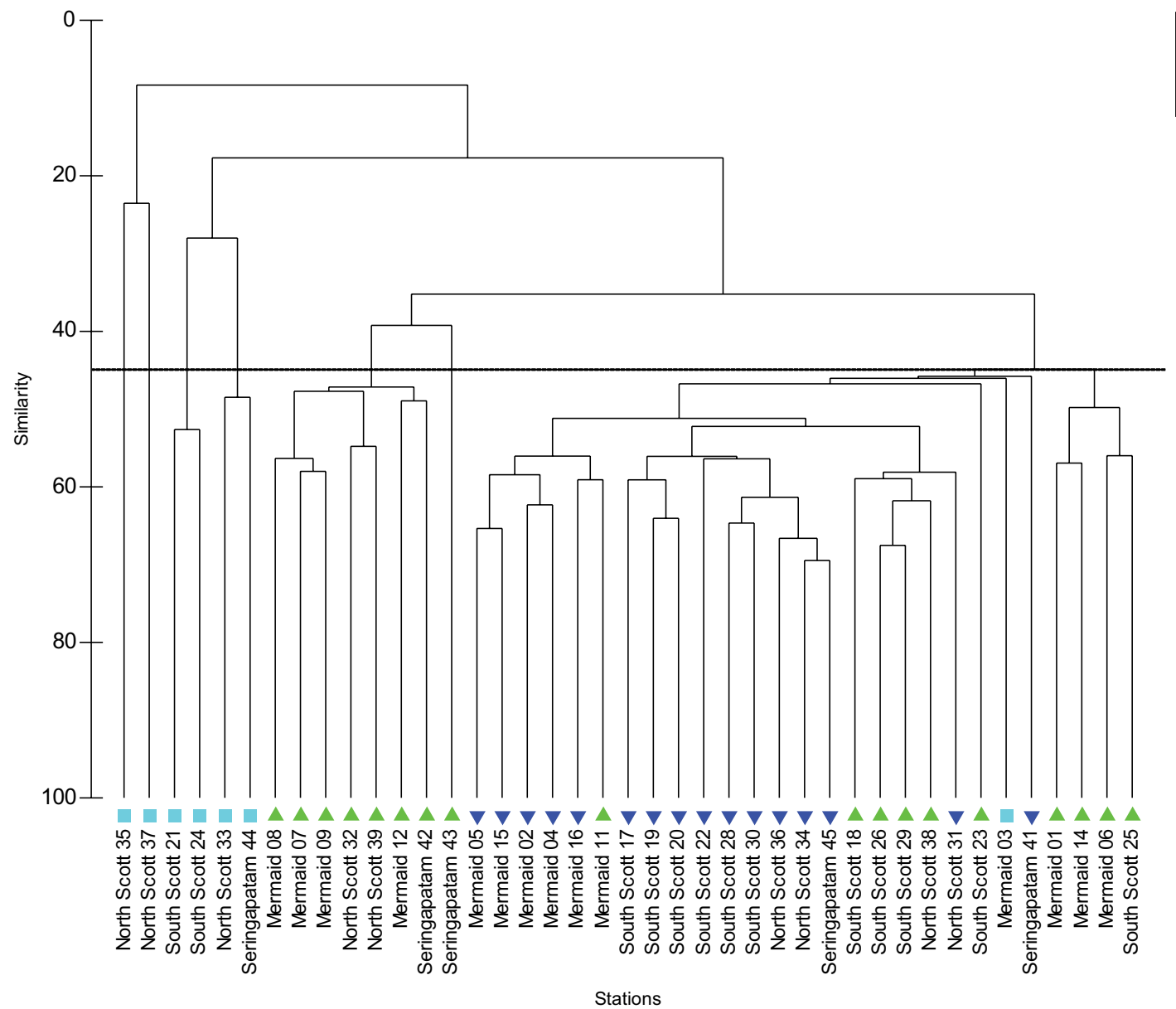

Figure 2 Dendrogram for hierarchical clustering of 41 stations at Mermaid, South Scott, North Scott and Seringapatam, using group-average linking of Bray-Curtis similarities, calculated on untransformed presence/absence data. A similarity level of $45 \%$ is indicated.

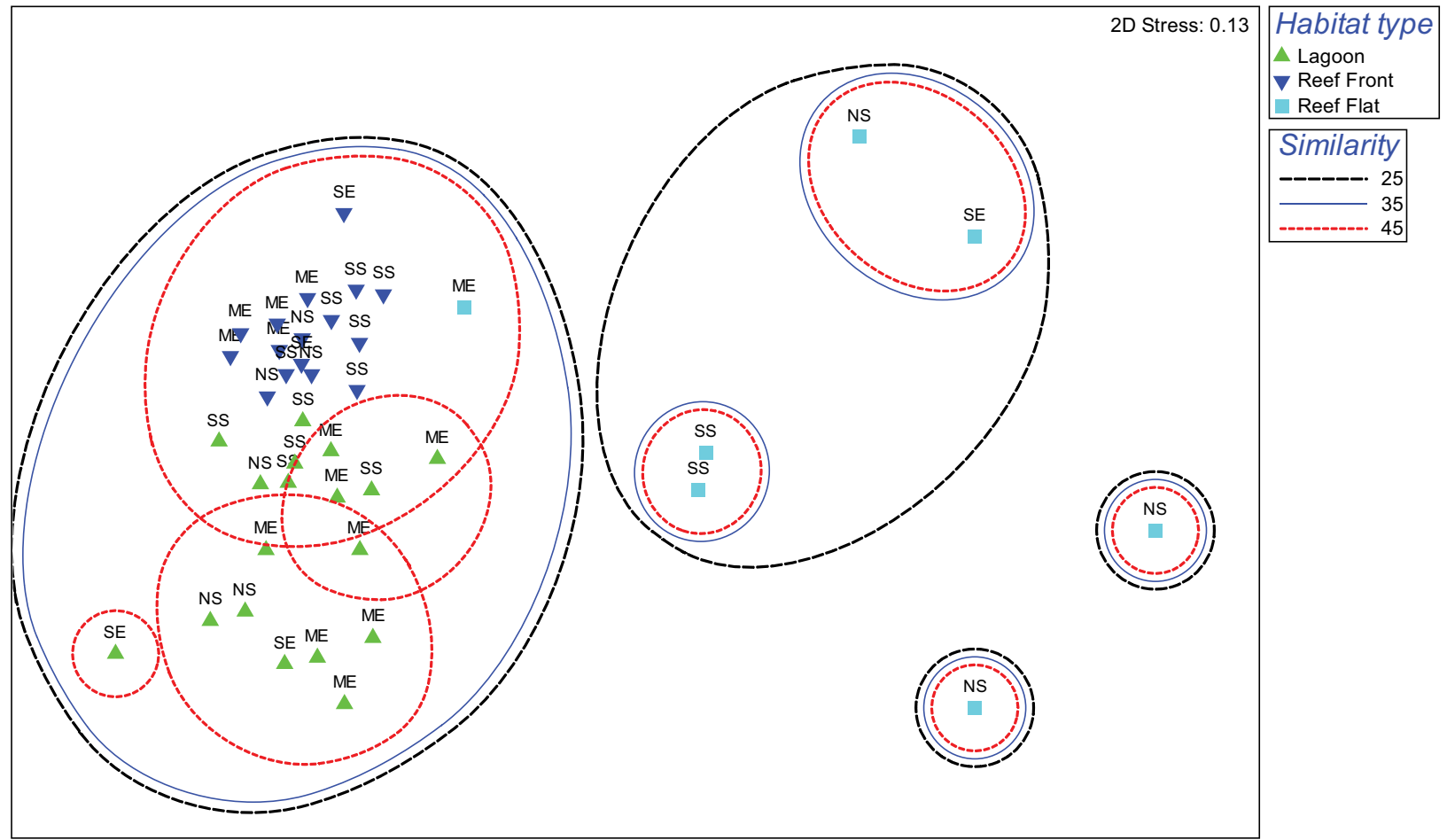

Figure 3 MDS ordination of 41 stations at Mermaid, South Scott, North Scott and Seringapatam, based on untransformed presence/absence data and Bray-Curtis similarities. Similarity contours from the cluster analysis at $25 \%, 35 \%$, and $45 \%$ are indicated. 


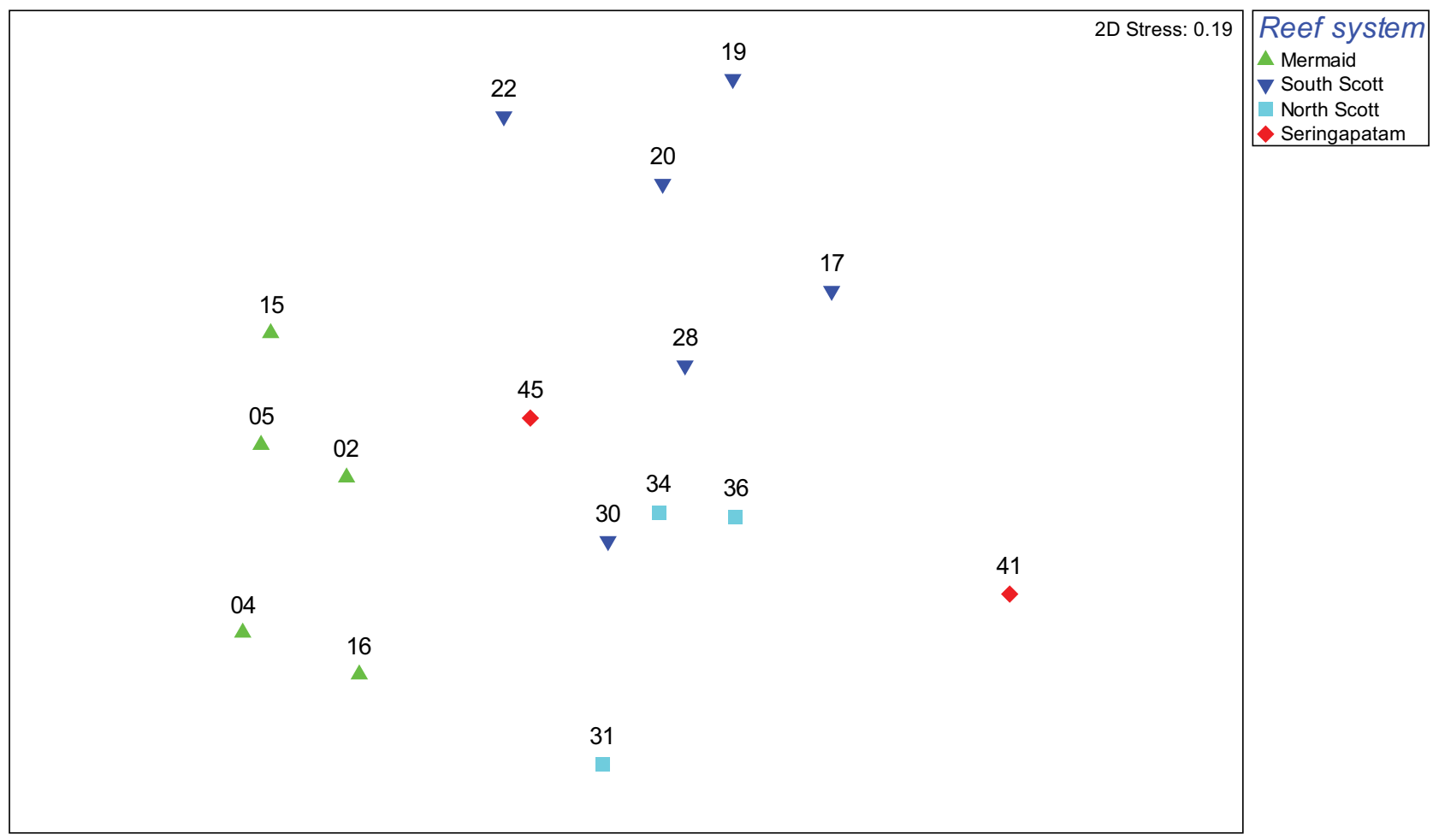

Figure 4 MDS ordination of 16 reef front stations at Mermaid, South Scott, North Scott and Seringapatam, based on untransformed presence/absence data and Bray-Curtis similarities.

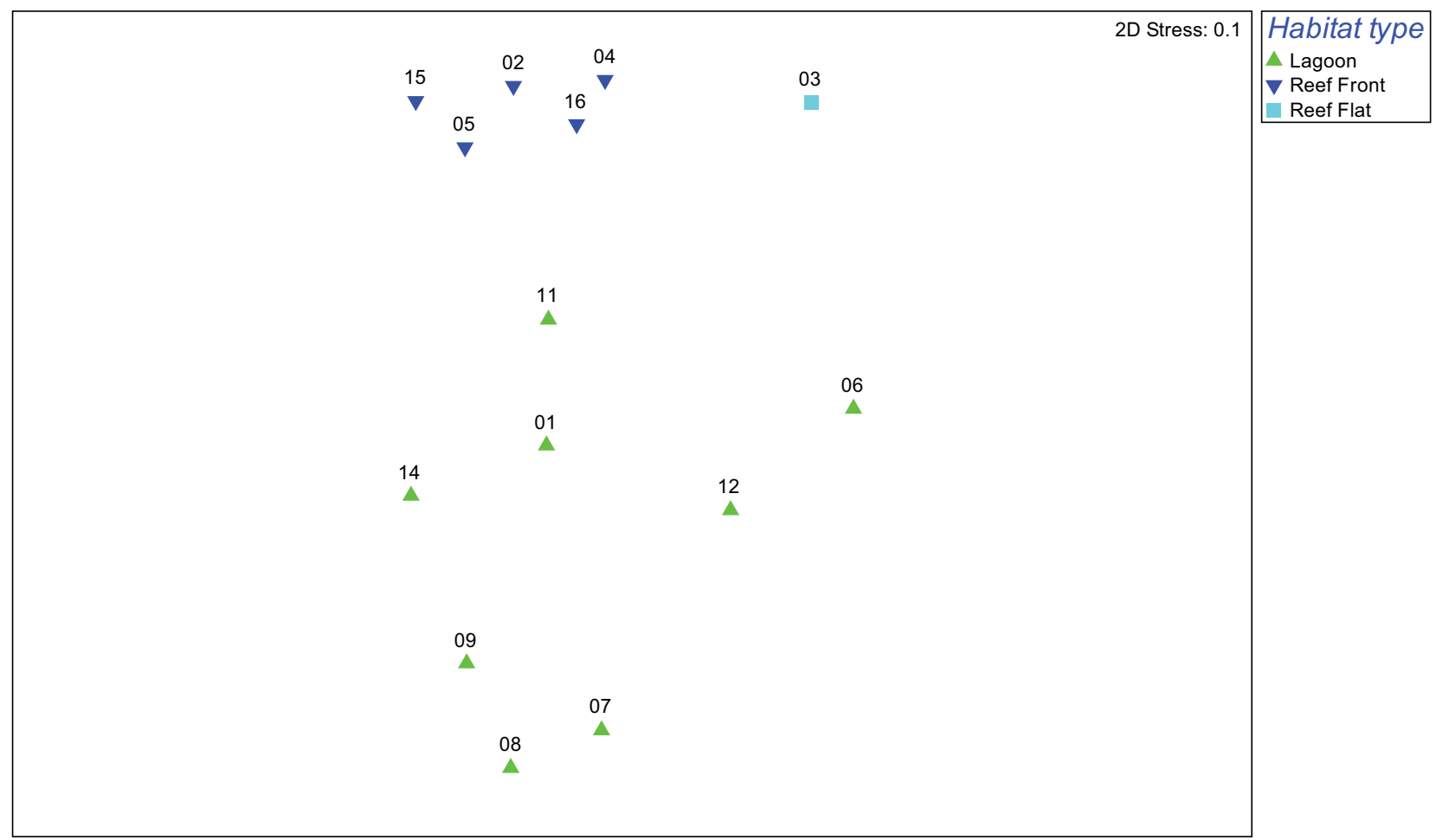

Figure 5 MDS ordination of 14 Mermaid stations, including reef front, lagoon, and intertidal reef flat habitats, based on untransformed presence/absence and Bray-Curtis similarities. 

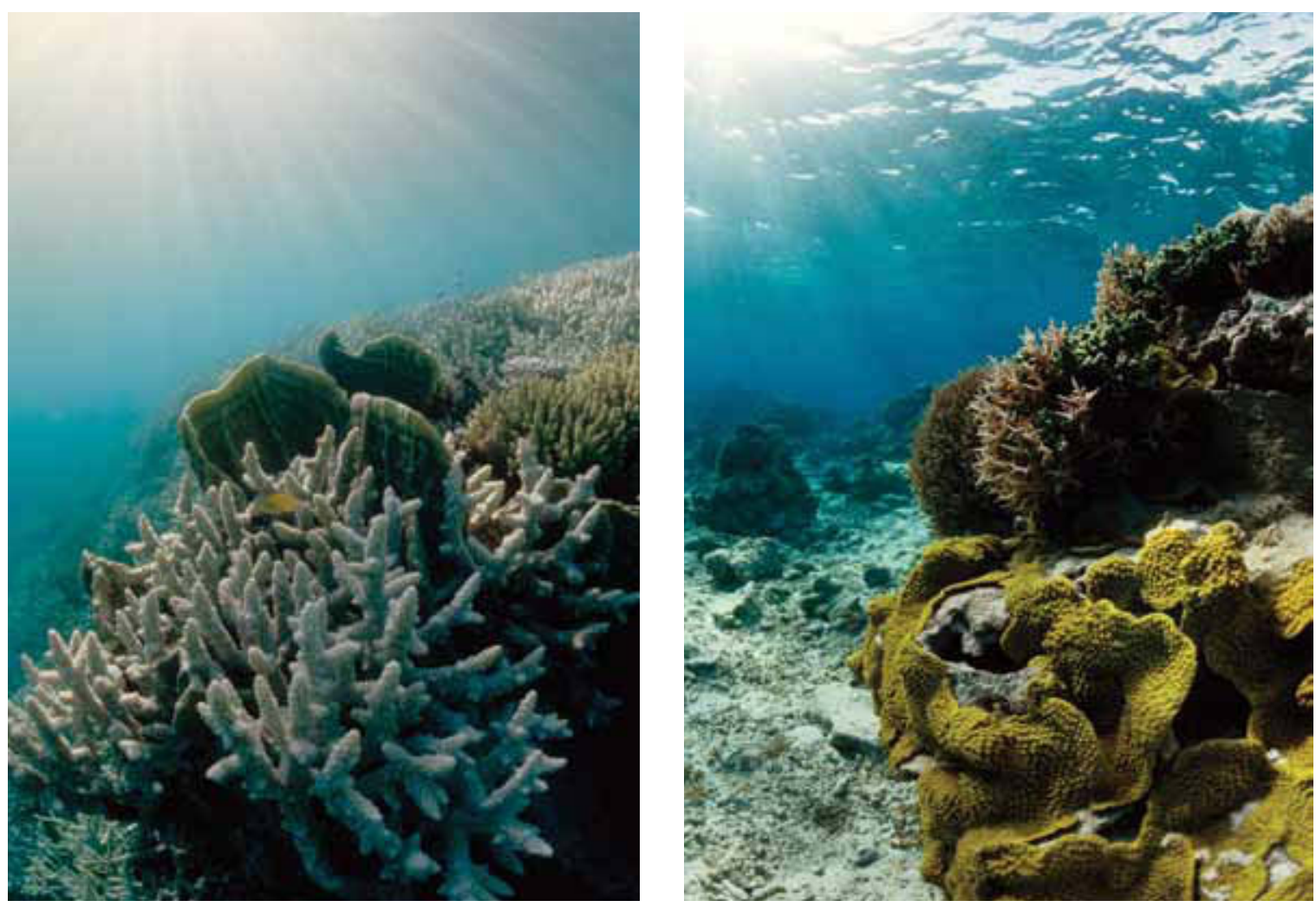

Left: Surveyed stations in Mermaid Reef lagoon displayed only minor cyclone damage; Right: The hard corals, Seriatopora (branching) and Turbinaria (encrusting) in the lagoon at Scott Reef. (Photos: Clay Bryce)

Wallace (1999) excluding A. exquisita, and the Fungiidae which follows Hoeksema (1989). Veron and Pichon (1975; 1980; 1982), Veron, Pichon and Wijsman-Best (1977), Veron and Wallace (1984) were also used to aid identification. The nonscleractinian species Heliopora coerulea, Tubipora musica and genus Millepora were also recorded during this survey.

Multivariate analyses of the two-way crossed survey design with replicates were performed using the software application PRIMER v6. A detailed discussion of these methods is provided in Clarke and Gorley (2006) and Clarke and Warwick (2001).

Deep and shallow transect data were aggregated in all analyses, as patterns of zonation with depth were relatively obscure within the higher-level patterns of habitat and reef system community similarity.

\section{RESULTS}

A total of 269 scleractinian species from 57 genera in 14 families were recorded during the present survey, comprised of 211 species at Mermaid, 224 species at South Scott, 201 species at North Scott, and 159 species at Seringapatam (Table 1).

The study yielded new distribution records for 22 species at Mermaid Reef and 18 species at Scott/Seringapatam. All new distribution records were small range extensions between individual reef systems in the Rowley-Scott complex, with the exception of Fungia moluccensis, a new record for Western Australia, and Montipora digitata, previously recorded from Ashmore Reef.

\section{Station richness}

Station richness recorded at all reef systems ranged from seven to 116 species per station (Table 1). Overall richness averaged 68 species per station, with mean values of 70 at Mermaid, 76 at South Scott, 60 at North Scott, and 55 at Seringapatam (Table 2). Intertidal stations were consistently depauperate (mean station richness $=23$ ), while reef front and lagoon stations had relatively high station richness (mean richness $=77$ ) (Figure 1). South Scott had four of the five highest station richness values recorded during the survey.

Nine of the 41 stations surveyed had high station richness ( $>80$ species per site), 23 stations had medium station richness ( $>50$ species), 6 stations had low richness (20-50 species), and three stations had very low richness ( $<20$ species). Many of the species recorded were relatively rare, with 21 species recorded only once during the survey. A large proportion of species were uncommon, with 169 species recorded at less than 10 stations. 22 species were abundant and were recorded at more than 25 stations. 

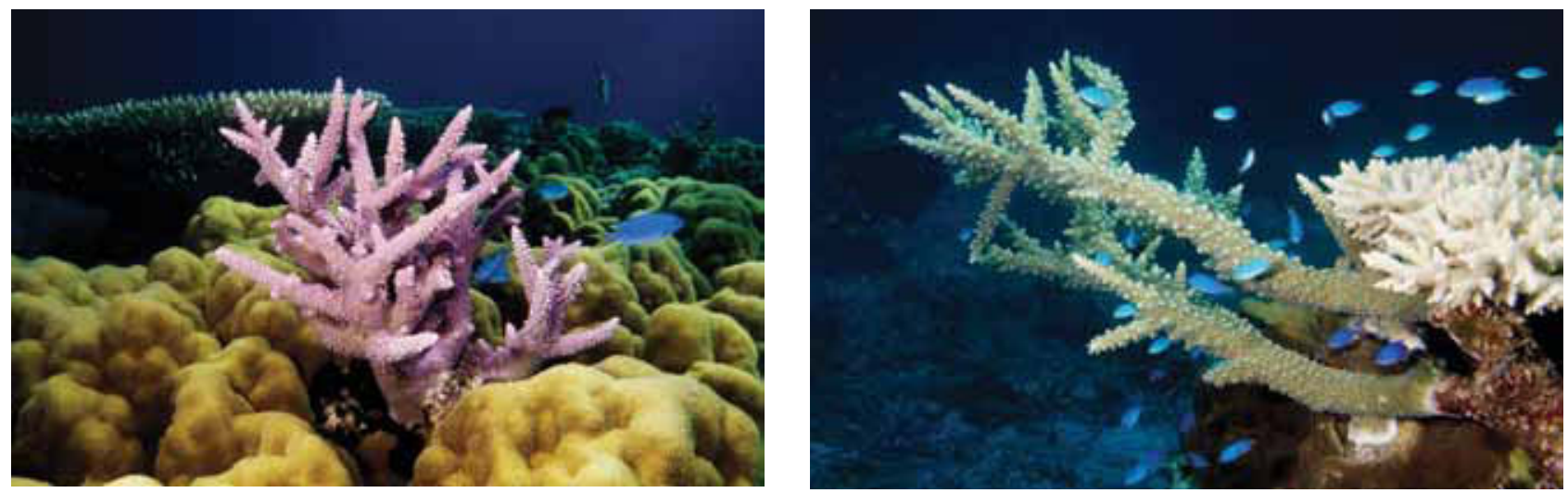

Left: Mermaid Reef. Branching Acropora and massive Porites corals; Right: Scott Reef. Acropora coral. (Photos: Clay Bryce)
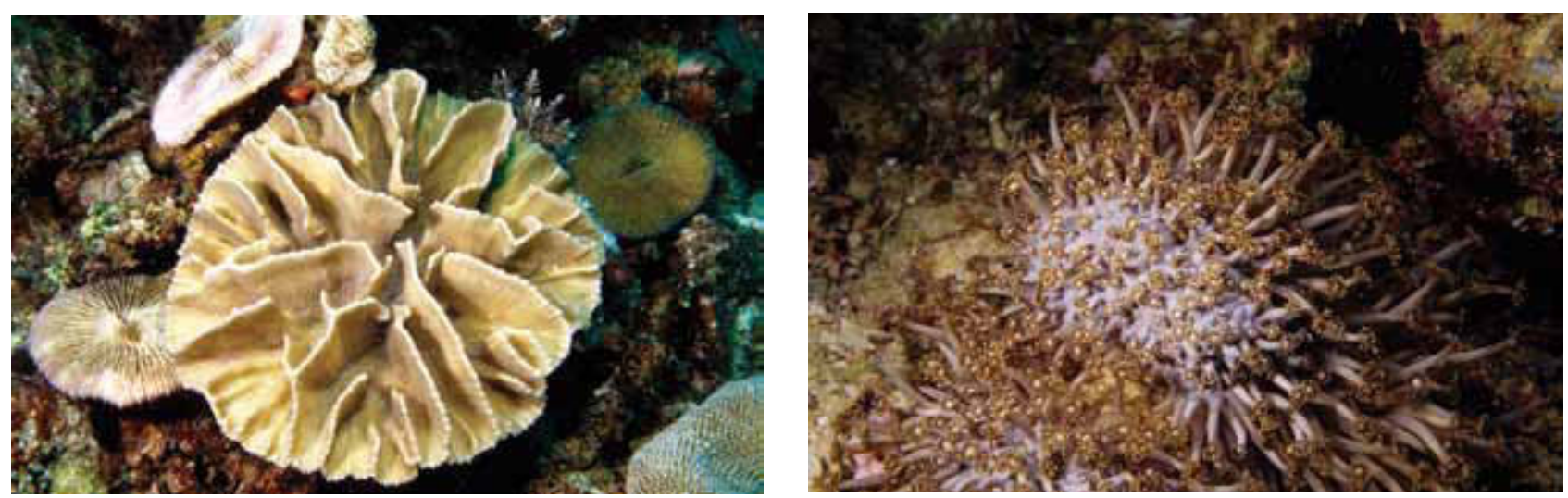

Left: Mermaid Reef. Fungia mushroom corals surround the coral Pectinia lactuca (Pallas, 1766); Right: Goniopora sp., with tentacles extended, was common on all reefs. (Photos: Clay Bryce)

\section{Community classification}

Multivariate classification and non-metric multidimensional scaling (MDS) analyses showed strong clustering of stations based on similarities among and within reef systems and habitat types (Figure $2,3)$.

Among reefs, strong clustering of stations occurred with habitat type. That is, habitat type was associated more strongly with community similarity than reef system location (Figure 3). Reef front stations were closely related between all reef systems, with Mermaid, South Scott, North Scott and Seringapatam reef front sites all strongly similar. Lagoon communities also clustered strongly, albeit it less than reef front stations, while intertidal reef flat stations clustered very weakly. Reef front and lagoon communities were more similar to each other than to intertidal communities.

Reef front stations at Mermaid were most closely related to reef front stations at North Scott. Reef front stations at South Scott were most closely related to reef stations at North Scott. Reef front stations at North Scott were intermediate between Mermaid and South Scott. Reef front stations at Seringapatam showed mixed affinities with
Mermaid, South Scott, and North Scott.

Lagoon stations at Mermaid were most closely related to a mix of lagoon stations at South Scott, North Scott and Seringapatam. Some Mermaid lagoon stations tended towards reef front communities. Lagoon stations at South Scott presented mixed affinities with lagoon stations at Mermaid, and were closely related to all reef front stations. Lagoon stations at North Scott were most closely related to lagoon stations at Mermaid and South Scott. Lagoon stations at Seringapatam were closely related to lagoon stations at North Scott and Mermaid.

Intertidal reef flat communities were strongly dissimilar to both reef front and lagoon communities, with the exception of the Mermaid reef flat station, which was closely related to all reef front stations and South Scott in particular. Intertidal stations at South Scott, North Scott and Seringapatam were related only loosely.

Within each of the major habitat-associated communities, distinct reef system sub-communities were present. Each habitat community was typically comprised of several smaller clusters of stations belonging to each of the different reef systems. For example, within the major reef front 


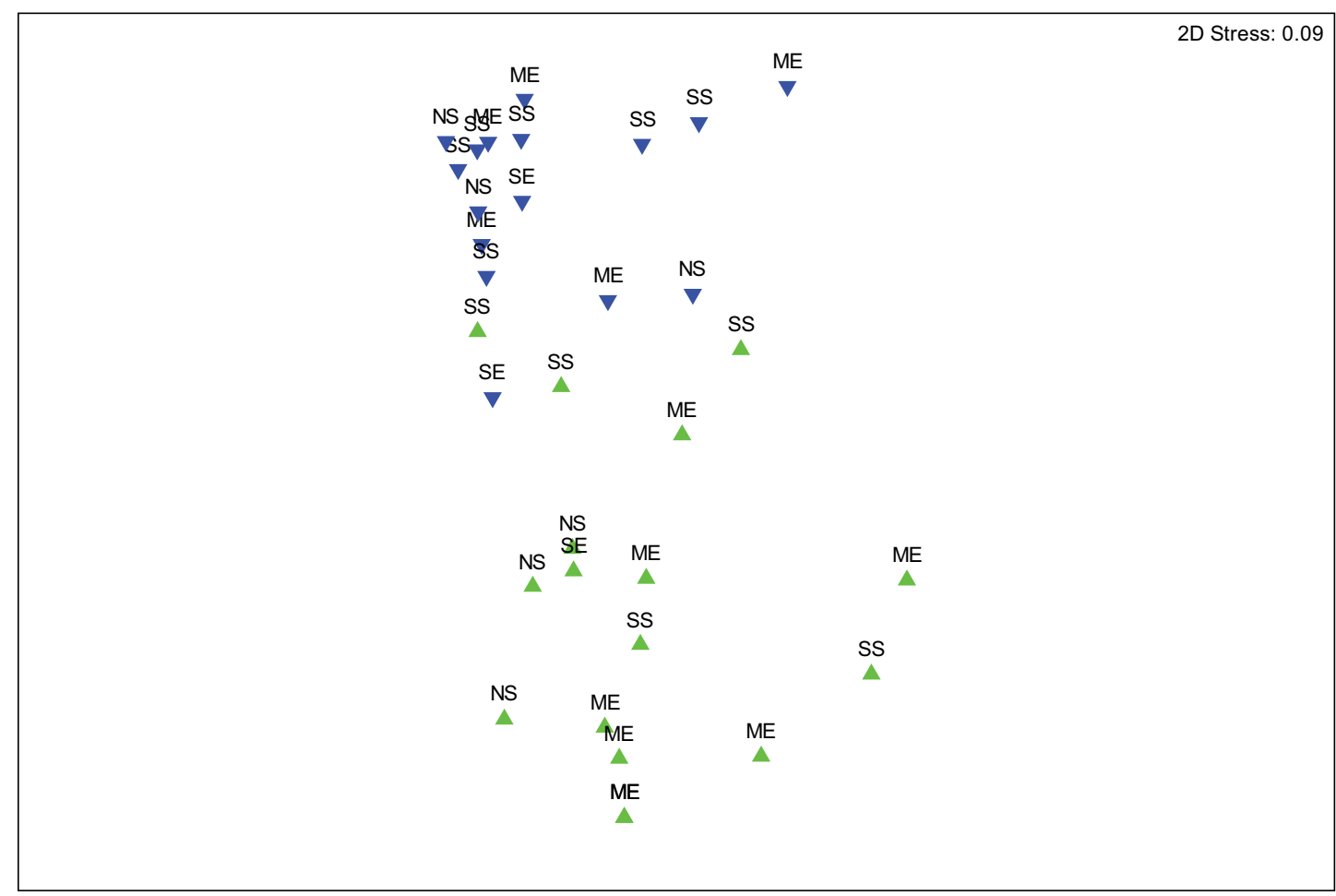

Figure 6 MDS ordination of 32 stations at Mermaid, South Scott, North Scott and Seringapatam, based on untransformed percent cover estimated from video transects, and Bray-Curtis similarities. Intertidal reef flat stations were not surveyed by video.

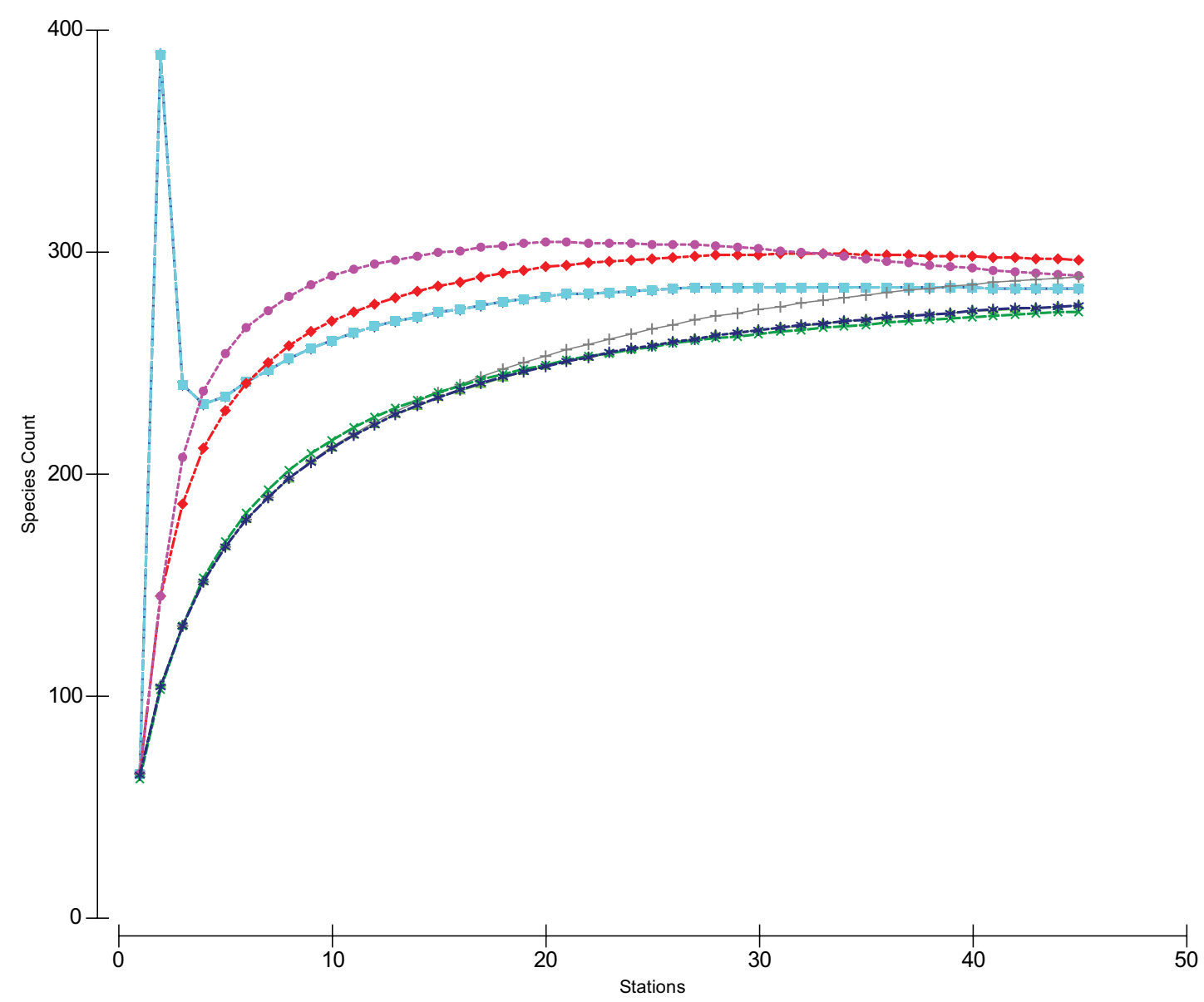

Figure 7 Combined species-area curve for all stations at Mermaid, South Scott, North Scott, and Seringapatam. Actual species counts are indicated (Sobs), as are projected values from Bootstrap, Jack-knife, Chao, and MichaelisMenton models. 


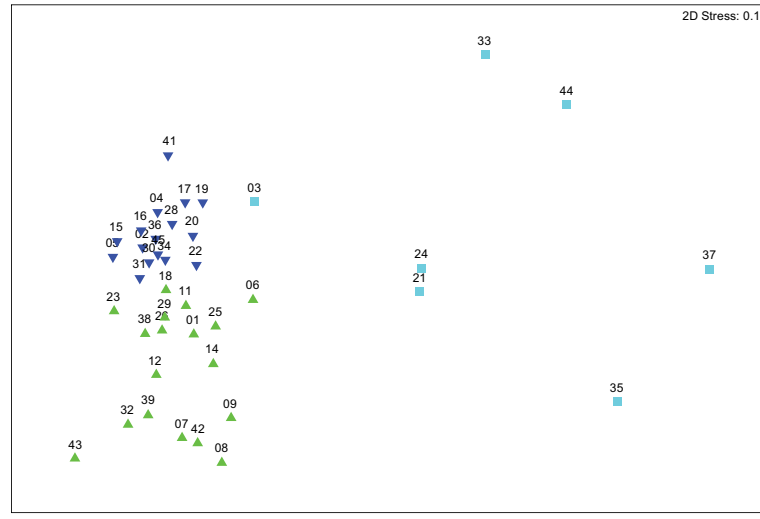

SPECIES LEVEL

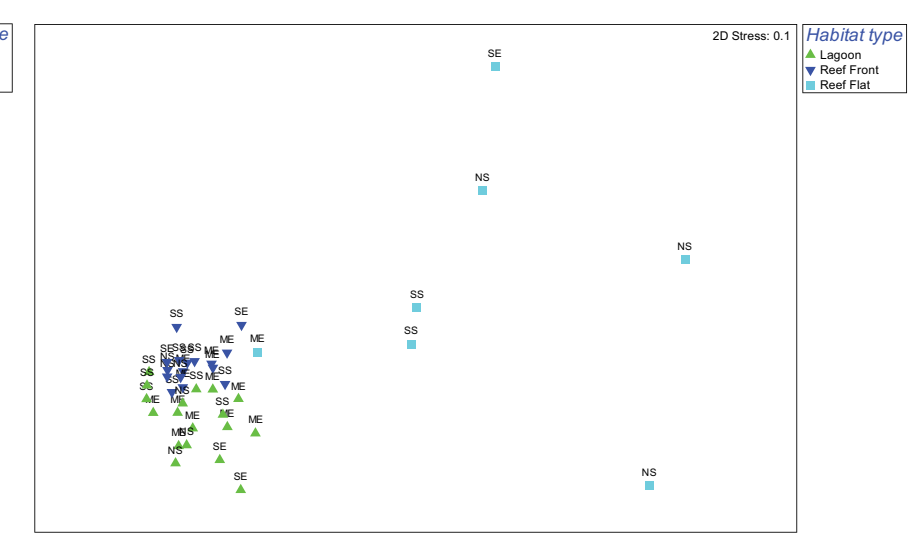

GENUS LEVEL

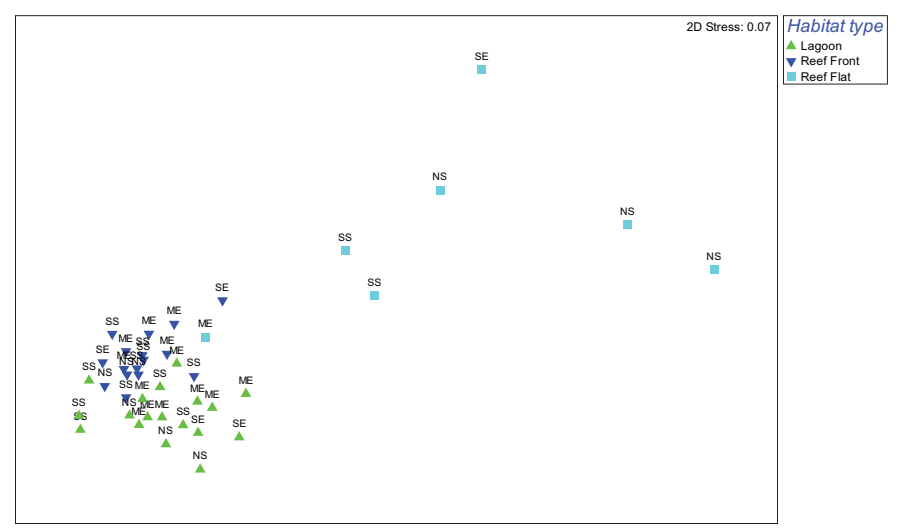

FAMILY LEVEL

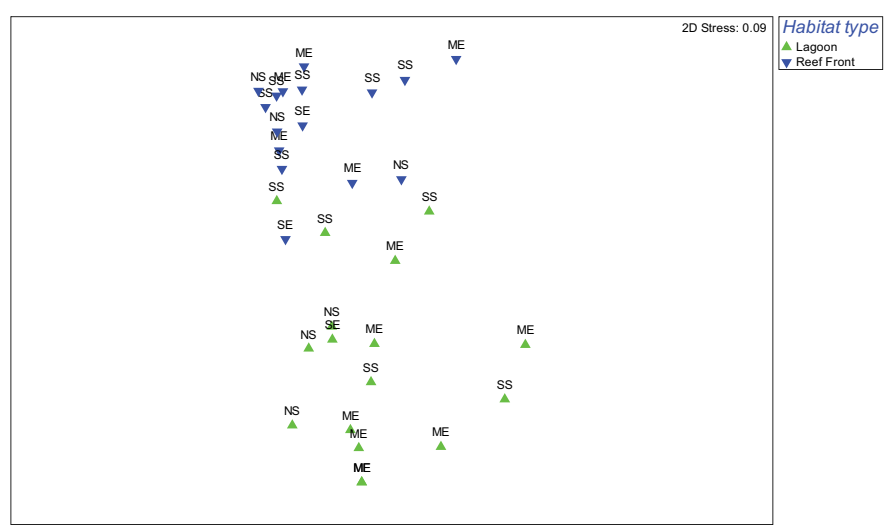

FUNCTIONAL LEVEL

Figure 8 MDS ordinations of 41 stations at the species, genus, family, and functional group levels, based on untransformed presence/absence data and percent cover, with Bray-Curtis similarities. Intertidal reef flat stations were not surveyed by video and are therefore excluded from the functional group level MDS.

cluster, Mermaid communities were distinct from the South Scott and North Scott communities, which were in turn similar to each other, while Seringapatam showed mixed affinities with Mermaid, South Scott and North Scott (Figure 4). These patterns of intra-habitat reef system segregation were repeated in the lagoon-associated communities across the four major reef systems. Intertidal reef flat segregation relationships were unclear.

Patterns of similarity were also apparent within individual reef systems, with distinct habitatassociated communities occurring within each reef. Within the Mermaid reef system, lagoon sites were clearly distinct from reef sites (Figure 5). The intertidal station was also distinct from the reef front sites. These patterns of intra-reefal habitat segregation were repeated in lagoon- associated communities across the four major reef systems.

Pair-wise analysis of similarity tests for differences between all habitat types were statistically significant $(\mathrm{p}<1 \%)$, with $\mathrm{R}$ scores ranging from 0.716 to 0.935 . Pair-wise tests for differences between all reef systems were also statistically significant $(\mathrm{p}<1 \%)$, with the exception of the North Scott-Seringapatam pair. R scores ranged from 0.344 to 0.657 . Complete analysis of similarities (ANOSIM) test values are given in Table 3.

\section{Benthic Cover}

Analyses of video transect data also showed strong clustering of communities at the functional group level associated with the lagoon and reef front habitats (Figure 6). Within the lagoonal cluster, smaller sub-clusters were associated with the Mermaid and North Scott reef systems. Mermaid and North Scott were similar to each other, while South Scott and Seringapatam were loosely grouped, with no clear affinities to other reef systems. Within the reef front cluster, no clear patterns were associated with any single reef system. Rather, the four reef systems showed mixed affinities with each other while remaining distinct from the lagoon communities. Intertidal reef flat transects were not surveyed by video, therefore no analyses could be performed for this habitat.

Hard coral cover was highest at Mermaid (29\%), followed by South Scott (21\%), North Scott (17\%), and Seringapatam (16\%). Hard coral cover was highest in the reef front habitats (25\%) followed by the lagoon habitats (22\%). 


\section{Habitats}

Habitat descriptor scores for each station are given in Table 4 . The major species that typify the lagoon, reef front, and reef flat habitats are given in Table 5, as are the major species that discriminate between each habitat group. The major functional groups that typify the lagoon, reef front, and reef flat habitats are given in Table 6, as are the major functional groups that discriminate between each habitat group.

Lagoon stations were characterised by protected sandy floor or mixed reef and rubble habitats, interspersed with isolated outcrops and bommies, simple, regular structural features, low wave energy, low to medium water clarity, and flat or low slopes, to 10-20m deep. Key groups of taxa were the branching Acroporas, and massive non-Acroporas.

Reef front stations were characterised by exposed coral and coralline algae covered limestone platforms, complex, irregular structural features, medium to high wave energy, medium to high water clarity, and steep slopes to a terrace at $12-18 \mathrm{~m}$ before an abrupt drop-off to very deep water. Key groups of taxa were the non-branching Acroporas and encrusting or massive non-Acroporas.

Intertidal reef flat stations were characterised by exposed combinations of reef crest zones, submerged elements of mixed reef, rubble, pavement and patch reefs, simple, regular structural features, medium to high wave energy, and extensive exposed reef flats at low tide. Key groups of taxa were the massive non-Acroporas, particularly Porites species.

\section{Species-area curves}

The cumulative species richness curve for the aggregated regional pool of the four major reef systems was close to reaching an asymptote, with few new discrete species encountered with additional station sampling in the region (Figure 7). However, examination of species-area curves for each separate reef system showed that individual

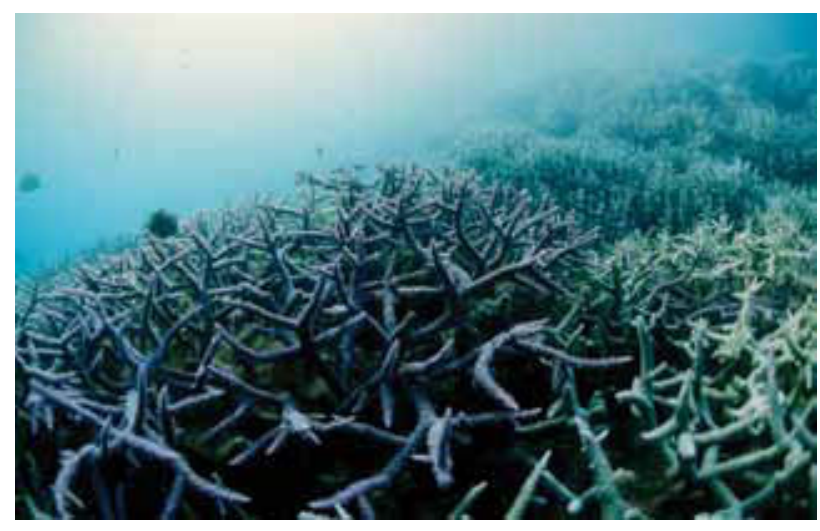

Above: An Acropora forest in the lagoon of Mermaid Reef. (Photo: Clay Bryce)

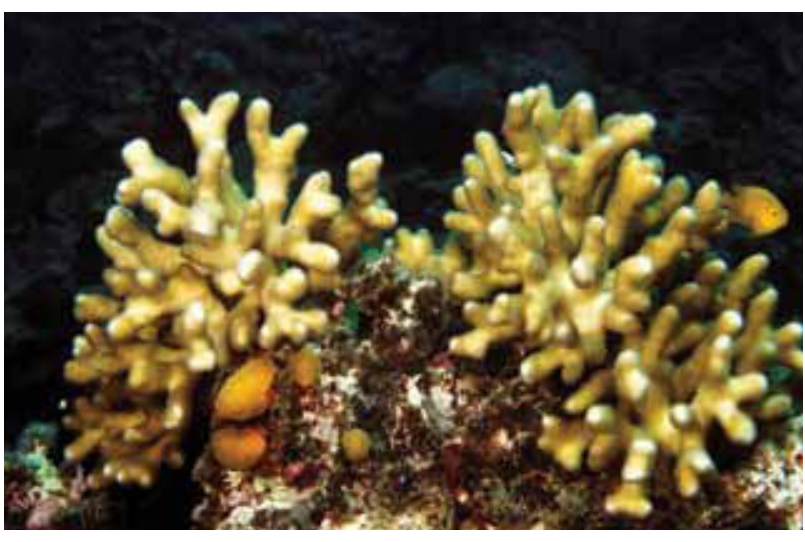

Above: The brooding coral, Stylophora pistallata Espar, 1797 (Photo: Clay Bryce)

reef species accumulations had not yet approached an asymptote, with new species continuing to be encountered with additional sampling. Estimates of the total number of species likely to be recorded in the Rowley-Scott region range from 273 to 296, based on a combination of Bootstrap, Jackknife, Chao, and Michaelis-Menton extrapolation models (Figure 7).

\section{Aggregated taxonomic levels}

MDS on aggregated taxonomic data at the levels of species, genus, family, and functional group showed similar community assemblages across multiple taxonomic levels, with the same overall patterns of community assemblages by site type and reef system (Figure 8). The species level data provide a detailed representation of community relatedness, with smaller sub-communities apparent at the species level, while genus and family level data display relatively similar, if less detailed, representations of relatedness. Functional group data provided a less clear picture of community relatedness.

\section{Transect Ratio}

The ratio of transect sightings to total sightings ranged very widely from $0 \%$ to $94 \%$. Reef front and lagoon stations presented high ratios $(79 \%$ and $74 \%$ respectively), while intertidal reef flat stations presented very low ratios (mean $32 \%$ ), often with all records made off the transect (Table 2).

\section{DISCUSSION}

The total number of species recorded during this survey combined with historical survey records brings total species richness for the oceanic RowleyScott atolls to 291 species. Local biodiversity is therefore considerably less than the approximate 600 species found in the 'Coral Triangle' area of highest diversity centered around the Philippines, Indonesia, and Papua New Guinea (Donnelly et 


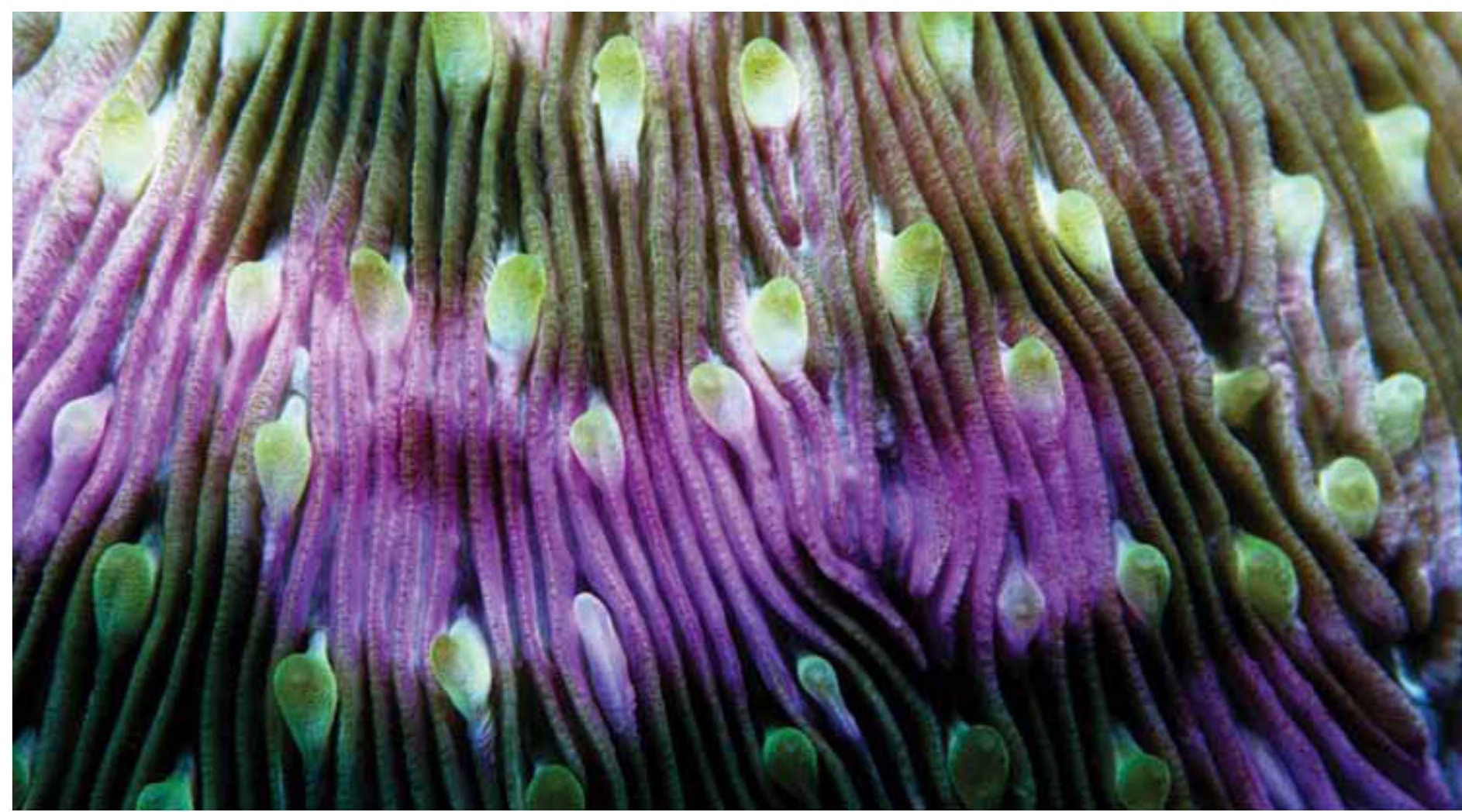

Above: Scott Reef. Close up detail of the free living Fungia mushroom coral. (Photo: Clay Bryce)

are all likely to have shaped the faunal assemblages encountered in the region.

Thus, the nature of the strong association observed between habitat and community structure cannot be attributed to any single key driver. Rather, further investigation is required to determine the relative contributions of each of the above factors to the overall patterns of biodiversity and abundance recorded in the region. Recent studies by AIMS (Smith et al., 2004) suggest that recruitment and gene flow processes in the region may be largely driven at local, within-reef scales, rather than on a regional scale in which the atolls were suggested as stepping stones through a larger bio-geographic province. It is likely that other complex patterns of relatedness, biodiversity, and community structure will be revealed with further research.

The strong effect of search effort on species richness capture during a survey is well known (Clarke and Warwick, 2001) and search effort is therefore a critical variable between studies. Most previous studies have tended to utilize a haphazard timed swim over a non-defined area to capture coral species richness at a station. These techniques may represent unequal search effort, and interpretation of results between these studies may therefore be limited.

Analyses in the present survey also suggest that the efficacy of different search methods may be strongly affected by patterns of local-scale variability and microhabitat heterogeneity. Station richness during the survey was influenced strongly by the presence or absence of microhabitats within the sampled area, and the power associated with low transect replication was often insufficient to accurately capture community structure. Intertidal reef flat communities, which were typically characterised by low diversity and abundance, had very high proportions of species recorded off the transect. In contrast, the use of transects at reef front and lagoon stations, with a short period of additional search time, were relatively effective in capturing the major components of station biodiversity. These problems of scale and patchiness, and the adequacy of transect replication, are therefore critical to the successful design and development of future sampling regimes and monitoring programs. Further research is needed to determine appropriate sampling scales and levels of replication for the large and complex reef systems encountered in the northwest oceanic atolls. Future analysis of transect species-area curve data collected during this survey will be useful in this context.

Species-area curve analyses at the level of individual reef systems did not reach an accumulation asymptote, suggesting a restricted estimate of the within-reef species pools. This is supported by the large number of new distribution records for the Rowley Shoals and Scott Reef. On a larger scale, the combination of the Mermaid, South 
Scott, North Scott, and Seringapatam richness data came close to reaching an asymptote, suggesting that total richness recorded during this survey may be close to total richness for the oceanic atolls. Further sampling, including examination of stations at Clerke and Imperieuse Reefs in the Rowley Shoals, would likely result in the upward revision of total biodiversity towards that predicted by the species-curve extrapolation models.

Non-metric MDS analyses on transect data aggregated to the higher taxonomic levels of genus and family presented strong similarities to that of data analysed at species level. Higherlevel taxonomic analyses may therefore represent a useful tool to detect key patterns of change in local community assemblages (Olsgard et al., 1998; Somerfield and Clarke, 1995). The power of such analyses remains to be determined, and while video transect analysis at the functional group level showed mixed results, Edinger and Risk (2000) reported successful prediction of coral reef conservation values based on morphological rather than taxonomic classification.

Further examination of voucher specimens collected during this survey is required and may result in additional records for the region. Ongoing review of the historical survey data is also required, as the major taxonomic revisions associated with the release of Veron (2000; 2002) resulted in the re-classification of several species recorded during historical surveys. Finally, recent methods in molecular phylogenetics suggest that the conventional taxonomic relationships used in this study may also undergo considerable revision in the future (Fukami et al., 2004).

\section{ACKNOWLEDGEMENTS}

I thank J. Fromont for co-ordinating my involvement in this survey, the crew of the Kimberley Quest for their assistance during the expedition, and M. Salotti who assisted with fieldwork preparations. L. DeVantier, D. Fenner, B. Hoeksema, and C. Wallace generously provided considerable identification assistance for which I am extremely grateful. L. Smith participated in many useful discussions on regional coral ecology and survey design. K.R. Clarke provided useful statistical and technical advice on the PRIMER software.

\section{REFERENCES}

Clarke, K. R., and Gorley, R. N. (2006). PRIMER v6 User Manual. PRIMER-E, Plymouth.

Clarke, K. R., and Warwick, R. M. (2001). Change in Marine Communities: An Approach to Statistical Analysis and Interpretation (2nd ed.). PRIMER-E, Plymouth.

DeVantier, L. M., De'ath, G., Turak, E., Done, T. J., and Fabricius, K. E. (2006). Species richness and community structure of reef-building corals on the nearshore Great Barrier Reef. Coral Reefs 25: 329-340.

Done, T. J. (1999). Coral community adaptability to environmental change at the scales of regions, reefs and reef zones. Am Zool 39: 66-79.

Done, T. J., and Marsh, L. M. (1988). Reef-building corals. In Berry, P. F. (ed.), Survey of the Marine Fauna of Christmas Island, Indian Ocean: 29-32. Western Australian Museum, Perth.

Done, T. J., Williams, D. M., Speare, P., Turak, E., Davidson, J., DeVantier, L. M., Newman, S. J., and Hutchins, J. B. (1994). Surveys of coral and fish communities at Scott Reef and Rowley Shoals. Townsville: Australian Institute of Marine Science.

Donnelly, R., Neville, D., and Mous, P. J. (eds.). (2003). Report on a rapid ecological assessment of the Raja Ampat Islands, Papua, Eastern Indonesia held October 30 - November 22, 2002. Sanur, Bali: The Nature Conservancy - Southeast Asia Center for Marine Protected Areas.

Edinger, E. N., and Risk, M. J. (2000). Reef classification by coral morphology predicts coral reef conservation value. Biological Conservation 92: 1-13.

Erdmann, M., and Pet-Soede, L. (eds.). (2003). Rapid Ecological Assessment of Wakatobi National Park. Denpasar: World Wildlife Fund.

Fukami, H., Budd, A. F., Paulay, G., Sole-Cava, A., Chen, C. A., Iwao, K., and Knowlton, N. (2004). Conventional taxonomy obscures deep divergence between Pacific and Atlantic corals. Letters to Nature 427: 832-835.

Gilmour, J. P., and Smith, L. D. (2006). Category 5 cyclone at Scott Reef, northwestern Australia. Coral Reefs 25: 200.

Green, A., and Mous, P. J. (2004). Delineating the Coral Triangle, its ecoregions and functional seascapes. Report on an expert workshop, held at the Southeast Asia Center for Marine Protected Areas, Bali, Indonesia. Denpasar: Report from The Nature Conservancy Southeast Asia Center for Marine Protected Areas.

Griffith, J. K. (1997). The Corals Collected During September/ October 1997 at Ashmore Reef, Timor Sea - a Report to Parks Australia. Retrieved 14 October, 2006, from http: / / www.deh.gov.au / coasts / mpa / ashmore / coral/index.html

Griffith, J. K. (2004). Scleractinian corals collected during 1998 from the Dampier Archipelago, Western Australia. In Jones, D. S. (ed.), Report of the Results of the Western Australian Museum/Woodside Energy Ltd Partnership to Explore the Marine Biodiversity of the Dampier Archipelago Western Australia 1998-2002. Records of the Western Australian Museum No 66: 101120. Western Australian Museum, Perth.

Heyward, A. J., Halford, A., Smith, L., and Williams, D. M. (1995). Coral ecosystems of north west Australia: Long-term monitoring of corals and fish at North Scott, South Scott and Seringapatam Reefs. Report 1: Baseline permanent transect surveys. Dampier: Australian Institute of Marine Science.

Heyward, A. J., Halford, A., Smith, L., and Williams, D. M. (1997). Coral reefs of north west Australia: Baseline 
monitoring of an oceanic reef ecosystem. Paper presented at the 8th International Coral Reef Symposium

Heyward, A. J., Smith, L., Halford, A. R., Rees, M., and Meekan, M. (1999). Natural variability at Scott Reef: short term response of coral and fish assemblages to a severe coral bleaching event. Dampier: Australian Institute of Marine Science.

Hoeksema, B. W. (1989). Taxonomy, phylogeny and biogeography of mushroom corals (Scleractinia: Fungiidae). Zoologische Verhandelingen 254: 1-295.

Marsh, L. M. (1992). Scleractinian and other hard corals. In Morgan, G. J. (ed.), Survey of the Aquatic Fauna of the Kimberley Islands and Reefs, Western Australia: 15-22. Western Australian Museum, Perth.

Marsh, L. M. (1993). Corals. In Berry, P. F. (ed.), A Survey of the Marine Fauna and Habitats of the Montebello Islands: 23-26. Western Australian Museum, Perth.

Marsh, L. M. (1995). Corals. In Hutchins, J. B., SlackSmith, S. M., Marsh, L. M., Jones, D. S., Bryce, C. W., Hewitt, M. A. \& Hill, A. (eds.), Marine Biological Survey of Bernier and Dorre Islands, Shark Bay. A joint production between the Western Australian Museum and the Western Australian Department of Conservation and Land Management, Perth.

Mora, C., and Robertson, R. (2005). Causes of latitudinal gradients in species richness: a test with fishes of the tropical Eastern Pacific. Ecology 86: 1771-1782.

Mous, P. J., Muljadi, A., and Pet, J. S. (2005). Status of coral reefs in and around Komodo National Park. Results of a bi-annual survey over the period 1996 - 2002 (July 2005). Sanur, Bali: Publication from The Nature Conservancy Southeast Asia Center for Marine Protected Areas.

Ninio, R., and Meekan, M. G. (2001). Spatial patterns in benthic communities and the dynamics of a mosaic ecosystem on the Great Barrier Reef, Australia. Coral Reefs 21: 95-103.

Olsgard, F., Somerfield, P. J., and Carr, M. R. (1998). Relationships between taxonomic resolution, macrobenthic community patterns and disturbance. Marine Ecology Progress Series 172: 25-36.

Smith, L. D., Gilmour, J. P., Heyward, A. J., and Rees, M. (in press). Mass-bleaching, mortality and slow recovery of three common groups of scleractinian corals at an isolated reef. Proceedings of the 10th International Coral Reef Symposium.

Smith, L. D., Gilmour, J. P., and Heyward, A. P. (in review). System-wide decline in coral abundance and recruitment following a catastrophic bleaching event. Unpublished manuscript, in review.

Smith, L. D., Gilmour, J. P., Rees, M., Lough, J., Halford, A. J., Underwood, J., Van Oppen, M., and Heyward, A. (2004). Biological and physical environment at Scott Reef: 2003 to 2004. Townsville: Australian Institute of Marine Science.

Somerfield, P. J., and Clarke, K. R. (1995). Taxonomic levels in marine community studies revisited. Marine Ecology Progress Series 127: 113-119.

Veron, J. E. N. (1986). Reef-building corals. In Berry, P. F. \& Marsh, L. M. (eds.), Faunal Surveys of the Rowley Shoals, Scott Reef and Seringapatam Reef North-western Australia. Records of the Western Australian Museum No 25: 27-35. Western Australian Museum, Perth.
Veron, J. E. N. (1989). Reef-building corals. In Berry, P. F. (ed.), Survey of the Marine Fauna of Cocos (Keeling) Islands, Indian Ocean. Western Australian Museum, Perth.

Veron, J. E. N. (1990). Re-examination of the reef corals of Cocos (Keeling) atoll. Records of the Western Australian Museum 14: 553-581.

Veron, J. E. N. (1993). Hermatypic corals of Ashmore Reef and Cartier Island. In Berry, P. F. (ed.), Marine Faunal Surveys of Ashmore Reef and Cartier Island NorthWestern Australia. Records of the Western Australian Museum Supplement No 44: 13-14. Western Australian Museum, Perth.

Veron, J. E. N. (2000a). Corals of the World (Vol. 1-3). Australian Institute of Marine Science, Townsville.

Veron, J. E. N. and Stafford-Smith, M. (2002). Coral ID. An electronic key to the zooxanthellate scleractinian corals of the World. Australian Institute of Marine Science, Townsville.

Veron, J. E. N. (2002). New Species Described in Corals of the World. Australian Institute of Marine Science, Townsville.

Veron, J. E. N., and Marsh, L. M. (1988). Hermatypic corals of Western Australia. Records and annotated species list. Records of the Western Australian Museum 29: 1-136.

Veron, J. E. N., and Pichon, M. (1975). Scleractinia of eastern Australia. Part I. Families Thamnasteriidae, Astrocoeniidae, Pocilloporidae. Australian Institute of Marine Science Monograph Series 1: 1-86.

Veron, J. E. N., and Pichon, M. (1980). Scleractinia of eastern Australia. Part III. Families Agariciidae, Siderastreidae, Fungiidae, Oculinidae, Merulinidae, Mussidae, Pectiniidae, Caryophylliidae, Dendrophylliidae. Australian Institute of Marine Science Monograph Series 3: 1-471.

Veron, J. E. N., and Pichon, M. (1982). Scleractinia of eastern Australia. Part IV. Family Poritidae. Australian Institute of Marine Science Monograph Series 5: 1-159.

Veron, J. E. N., Pichon, M., and Wijsman-Best, M. (1977). Scleractinia of eastern Australia. Part II. Families Faviidae, Trachyphylliidae. Australian Institute of Marine Science Monograph Series 3: 1-233.

Veron, J. E. N., and Wallace, C. C. (1984). Scleractinia of eastern Australia. Part V. Family Acroporidae. Australian Institute of Marine Science Monograph Series 6: $1-485$.

Wallace, C. C. (1999). Staghorn Corals of the World. CSIRO Publications, Collingwood.

Warwick, R. M., and Clarke, K. R. (1995). New 'biodiversity' measures reveal a decrease in taxonomic distinctness with increasing stress. Marine Ecology Progress Series 129: 301-305.

Wolstenholme, J., and Smith, L. (unpublished data). Unpublished data. Surveys of coral communities at Scott Reef and Seringapatam. Townsville: Australian Institute of Marine Science. 


\section{Appendix}

Table 1 Species recorded at Mermaid, South Scott, North Scott and Seringapatam Reefs, 2006. New records at Rowley Shoals are noted with ${ }^{\mathrm{R}}$. New records at Scott Reef are noted with ${ }^{\mathrm{S}}$. Species previously recorded in the region and not found during the present survey are noted with ${ }^{\mathrm{P}}$.

\begin{tabular}{|c|c|c|c|c|c|c|c|c|c|c|c|c|c|c|c|c|c|}
\hline \multirow[b]{2}{*}{ Species } & \multirow[b]{2}{*}{ Authority } & \multicolumn{16}{|c|}{ Mermaid } \\
\hline & & 01 & 02 & 03 & 04 & 05 & 06 & 07 & 08 & 09 & 10 & 11 & 12 & 13 & 14 & 15 & 16 \\
\hline \multicolumn{18}{|l|}{ Acroporidae } \\
\hline Acropora abrolhosensis & Veron, 1985 & 1 & & & & & 1 & 1 & 1 & 1 & & & 1 & & 1 & & \\
\hline Acropora abrotanoides & (Lamarck, 1816) & & & & & & & & & & 1 & & & & & & \\
\hline Acropora aculeus & (Dana, 1846) & & & & & 1 & & & & & & & & & & 1 & \\
\hline Acropora acuminata & (Verrill, 1864) & & & & & & & & & & & & & & & & \\
\hline Acropora anthocercis & (Brook, 1893) & 1 & & & & & & & & & & & & 1 & & 1 & \\
\hline Acropora aspera & (Dana, 1846) & & & & & & & & & & & & & & 1 & & \\
\hline Acropora austera & (Dana, 1846) & & & & & & & & & & & & & 1 & & & \\
\hline Acropora carduus ${ }^{R}$ & (Dana, 1846) & 1 & & & & & & 1 & 1 & 1 & & & & & 1 & & \\
\hline Acropora carolinianas & Nemenzo, 1976 & & & & & 1 & & & & & & & & & 1 & & \\
\hline Acropora cerealis & (Dana, 1846) & & & & & 1 & & 1 & & & 1 & & 1 & & 1 & 1 & \\
\hline Acropora clathrata & (Brook, 1891) & 1 & & & & & & & & & & 1 & 1 & & & & \\
\hline Acropora cytherea & (Dana, 1846) & & & & & & & & & & & 1 & & & & & \\
\hline Acropora digitifera & (Dana, 1846) & 1 & & 1 & & & 1 & & & & & & & & 1 & & \\
\hline Acropora divaricata & (Dana, 1846) & & & & & & & & & & & & & & & & \\
\hline Acropora donei & Veron and Wallace, 1984 & & & & & & & & & & & & & 1 & & & \\
\hline Acropora echinata & (Dana, 1846) & & & & & & & & 1 & 1 & & & & & & & \\
\hline Acropora elseyi & (Brook, 1892) & 1 & & & & & & & & & & & & & 1 & & \\
\hline Acropora exquisita & Nemenzo, 1971 & 1 & & & & & & 1 & 1 & & & & 1 & & & & \\
\hline Acropora florida & (Dana, 1846) & 1 & & & & & 1 & 1 & 1 & 1 & & 1 & 1 & & 1 & & \\
\hline Acropora gemmifera & (Brook, 1892) & & & 1 & 1 & 1 & 1 & & & & & & 1 & & & 1 & \\
\hline Acropora glauca & (Brook, 1893) & & & & & & & & & & 1 & & & & & & \\
\hline Acropora grandis & (Brook, 1892) & & & & & 1 & 1 & & 1 & & & & & & 1 & & \\
\hline Acropora granulosa ${ }^{R}$ & (Milne Edwards and Haime, 1860) & & 1 & & & 1 & & & & & & & & 1 & & & \\
\hline Acropora horrida & (Dana, 1846) & 1 & & & & & & & & & & & 1 & & & & \\
\hline Acropora humilis & (Dana, 1846) & 1 & 1 & 1 & & 1 & 1 & 1 & & 1 & 1 & 1 & 1 & & 1 & 1 & \\
\hline Acropora hyacinthus & (Dana, 1846) & 1 & & 1 & & 1 & 1 & & & & 1 & & 1 & 1 & 1 & 1 & \\
\hline Acropora indonesia & Wallace, 1997 & & & & & & & & & & & & & & & & \\
\hline Acropora intermedia & (Brook, 1891) & 1 & & & & 1 & 1 & 1 & 1 & 1 & & 1 & 1 & & 1 & & \\
\hline Acropora kimbeensis $^{P}$ & Wallace, 1999 & & & & & & & & & & & & & & & & \\
\hline Acropora kirstyae $^{P}$ & Veron and Wallace, 1984 & & & & & & & & & & & & & & & & \\
\hline Acropora latistella & (Brook, 1891) & & & & & & & & & & 1 & & & & & 1 & \\
\hline Acropora listeri & (Brook, 1893) & & & 1 & 1 & & & & & & 1 & & & & & & \\
\hline Acropora loisetteae ${ }^{R}$ & Wallace, 1994 & & & & & & & 1 & & 1 & & & & & 1 & & \\
\hline Acropora longicyathus & (Milne Edwards and Haime, 1860) & 1 & & & & & & & & & & & & & & & \\
\hline Acropora loripes & (Brook, 1892) & & 1 & & 1 & & & & & & 1 & & & 1 & & 1 & 1 \\
\hline Acropora lutkeni & Crossland, 1952 & & & & & & & & & & 1 & & & & & & \\
\hline Acropora microclados & (Ehrenberg, 1834) & & & & & 1 & & & & & 1 & & & 1 & & & 1 \\
\hline Acropora microphthalma & (Verrill, 1859) & 1 & & & & & 1 & 1 & 1 & 1 & & 1 & & & 1 & & \\
\hline Acropora millepora & (Ehrenberg, 1834) & 1 & 1 & 1 & & & 1 & & & & & 1 & & 1 & 1 & 1 & \\
\hline Acropora monticulosa & (Brueggemann, 1879) & 1 & 1 & 1 & 1 & & & & & & & & & 1 & 1 & 1 & 1 \\
\hline Acropora muricata & (Linnaeus, 1758) & 1 & 1 & & & & & 1 & & 1 & & 1 & & & 1 & & \\
\hline
\end{tabular}




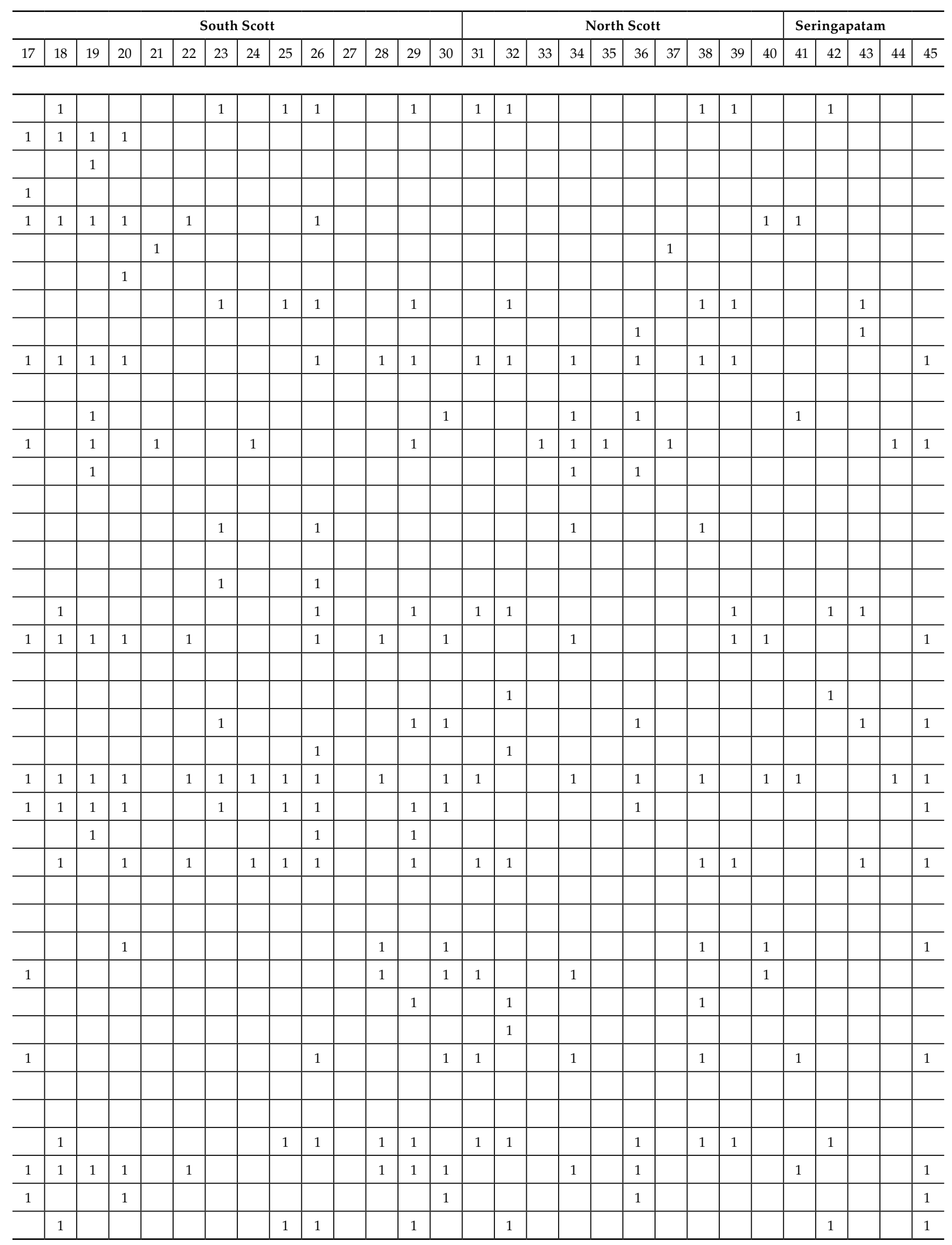




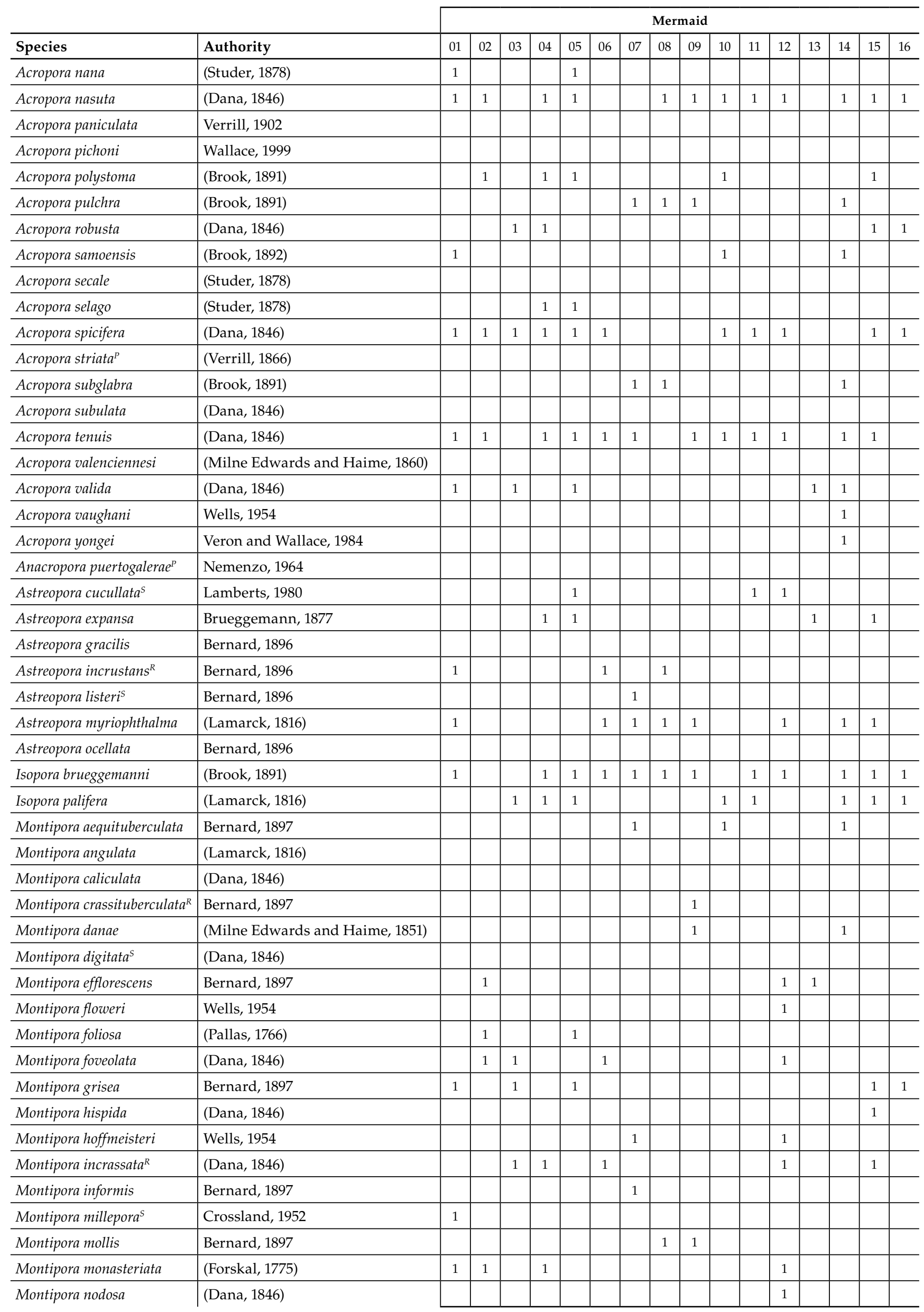




\begin{tabular}{|c|c|c|c|c|c|c|c|c|c|c|c|c|c|c|c|c|c|c|c|c|c|c|c|c|c|c|c|c|c|}
\hline \multicolumn{15}{|c|}{ South Scott } & \multicolumn{10}{|c|}{ North Scott } & \multicolumn{5}{|c|}{ Seringapatam } \\
\hline 17 & 18 & 19 & 20 & 21 & 22 & 23 & 24 & 25 & 26 & 2 & 28 & & & 30 & 31 & 32 & 33 & 34 & 35 & 36 & 37 & 38 & 39 & 40 & 41 & 42 & 43 & 44 & 45 \\
\hline 1 & & 1 & & & & & & & & & & & & & & & & 1 & & 1 & & & & & 1 & & & & \\
\hline \multirow[t]{5}{*}{1} & 1 & 1 & 1 & & & 1 & & 1 & 1 & & 1 & & & & 1 & & & 1 & & 1 & & 1 & 1 & & 1 & 1 & & & 1 \\
\hline & & & & & & 1 & & & & & & & & & & & & 1 & & & & & & & & & & & \\
\hline & & & 1 & & & & & & & & & & & & & & & & & & & & & & & & & & \\
\hline & & & & & & & & & & & 1 & & & & & & & & & & & & & 1 & 1 & . & & & \\
\hline & & & & & & & & & & & & & & & & 1 & & & & & & & & & & 1 & & & \\
\hline 1 & 1 & & 1 & & & & & & & & & & & & & & & & & & 1 & & & & & & & & \\
\hline \multirow[t]{2}{*}{1} & & & & & & & & & 1 & & 1 & & & & 1 & & & 1 & & 1 & & & 1 & & & & & 1 & \\
\hline & & & 1 & & & 1 & & & & & & & & & & & & & & & & & & & & & & & 1 \\
\hline 1 & 1 & & & & & & & 1 & 1 & & 1 & & & & & 1 & & & & & & & & & & & & & \\
\hline \multirow[t]{2}{*}{1} & 1 & 1 & 1 & & 1 & 1 & 1 & 1 & 1 & & 1 & & & 1 & 1 & & & 1 & & 1 & & & & 1 & 1 & & & & 1 \\
\hline & 1 & & & & & 1 & & 1 & 1 & & & & & & & 1 & & & & & & 1 & 1 & & & & 1 & & \\
\hline \multirow[t]{3}{*}{1} & & & & & & 1 & & & 1 & & & & & 1 & 1 & & & 1 & & 1 & & & 1 & 1 & 1 & & & & 1 \\
\hline & 1 & 1 & 1 & & & 1 & & 1 & 1 & & 1 & & & 1 & 1 & & & 1 & & 1 & & & & & & & & & 1 \\
\hline & & & & & & 1 & & & & & & & & & & & & & & & & & & & & & & & \\
\hline \multirow[t]{4}{*}{1} & 1 & 1 & & & 1 & & & & & & & & & & & & & & & 1 & & & & 1 & & & & & 1 \\
\hline & & & & & & & & & & & & & & & & & & & & & & & & & & & & & \\
\hline & & & & & & & & & & & & & & & & & & & & & & & & & & & & & \\
\hline & & & & & & & & & & & & & & & & & & & & & & & & & & & & & \\
\hline \multirow[t]{4}{*}{1} & 1 & 1 & & & 1 & & & & & & & & & 1 & & 1 & & 1 & & 1 & & 1 & 1 & & & 1 & & & 1 \\
\hline & & & & & & & & & & & & & & & & & & & & & & & & & & & & & \\
\hline & & & & & & 1 & & 1 & 1 & & 1 & & & 1 & & . & & 1 & & 1 & & 1 & 1 & & & & 1 & & 1 \\
\hline & 1 & & & & 1 & & & & & & & & & & & 1 & & & & & & & & & & 1 & 1 & & \\
\hline 1 & & & & & & & & & 1 & & & & & & & & & & & & & & & & & . & 1 & & \\
\hline & 1 & & 1 & & 1 & 1 & 1 & 1 & 1 & & 1 & & & 1 & 1 & 1 & 1 & 1 & & 1 & & & & & & 1 & 1 & & 1 \\
\hline & & & & & & & & & & & & & & & & & & & & & & & & & & 1 & & & \\
\hline & 1 & & & & & & & & 1 & & & & & 1 & 1 & & & 1 & & 1 & & 1 & 1 & & & 1 & & & 1 \\
\hline 1 & 1 & 1 & 1 & & 1 & & & & & & 1 & & & 1 & 1 & & & 1 & & 1 & & & & & 1 & & & & 1 \\
\hline & & & & & & & & & & & & & & & & & & & & & & & & & & & & & \\
\hline & & & & & & & & & & 1 & & & & & & & & & 1 & & & & & & & & & & \\
\hline & 1 & 1 & & & & & & & & & & & & & & & & 1 & & & & & & & & & & & \\
\hline & & & & & & & & 1 & 1 & & & & & & & & & & & & & & & & & & & & \\
\hline & & & & & & & & & 1 & & & & & & & 1 & & & 1 & & & 1 & & & & 1 & 1 & & \\
\hline & & & & 1 & & & 1 & & & & & & & & & & & & & & & & & & & & & & \\
\hline & 1 & & 1 & & & 1 & & & & & & & & 1 & 1 & & & & & & & 1 & & & & & & & \\
\hline & . & & & & & & & & & & & & & & & & & & & & & & & & & & & & \\
\hline & 1 & & & & & & & & 1 & & & & & & & & & & & & & & & & & & & & 1 \\
\hline & 1 & 1 & 1 & & & & & 1 & & & 1 & & & 1 & & & & & & 1 & 1 & & & 1 & & & & & \\
\hline 1 & & & 1 & & 1 & & & 1 & & & 1 & & & 1 & 1 & & & 1 & & 1 & & & & & 1 & & & & \\
\hline & & 1 & & & & & & & 1 & & & & & & & & & & & & & & & & & & & & \\
\hline & & & & & & & & & & & & & & & & & & & & & & & & & & 1 & & & \\
\hline & 1 & 1 & & & & & & & & & & & & & & & 1 & & & & & & & 1 & & & 1 & & \\
\hline & 1 & 1 & 1 & & & & & & & & 1 & & & & & & & & & & & 1 & & & & 1 & 1 & & \\
\hline & & & & & & & & & & & & & & & & & & 1 & & & & & & & & & & & \\
\hline & & 1 & 1 & & & & 1 & & & & & & & & & 1 & & . & & & & & & & & & & & \\
\hline & 1 & & & & & 1 & & & 1 & & & & & 1 & 1 & & & 1 & & & & & & & & & & & \\
\hline & & & & & & & & & & & & & & & & & & & & & & & & & & & & & \\
\hline
\end{tabular}




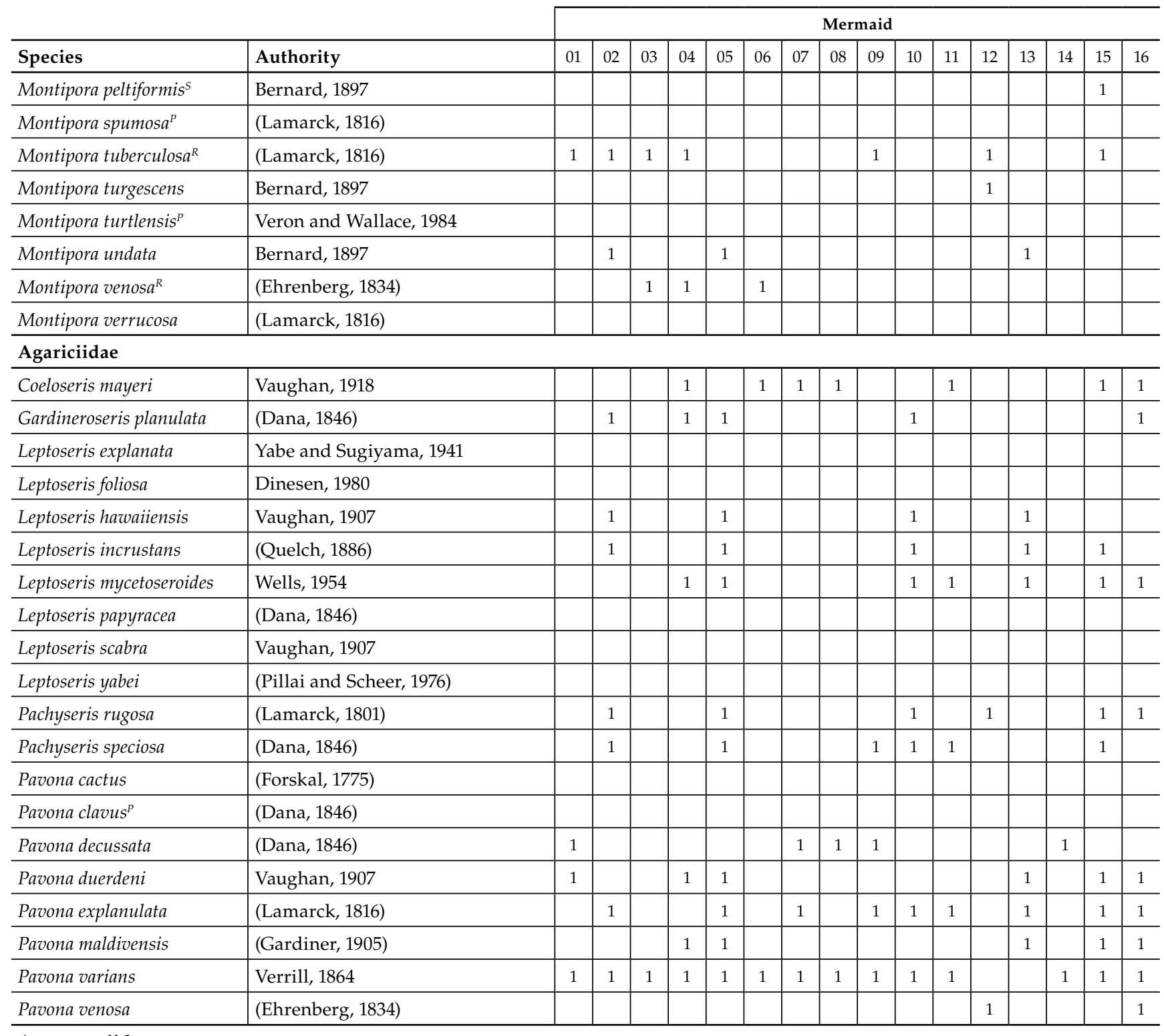

\section{Astrocoeniidae}

\begin{tabular}{|c|c|c|c|c|c|c|c|c|c|c|c|c|}
\hline Stylocoeniella armata & (Ehrenberg, 1834) & 1 & 1 & 1 & & & & & & & 1 & \\
\hline Stylocoeniella guentheri & Bassett-Smith, 1890 & & & & 1 & 1 & & & & 1 & & \\
\hline \multicolumn{13}{|l|}{ Dendrophylliidae } \\
\hline Turbinaria frondens & (Dana, 1846) & & & & & & & & & & & \\
\hline Turbinaria mesenterina $^{P}$ & (Lamarck, 1816) & & & & & & & & & & & \\
\hline Turbinaria peltata ${ }^{P}$ & (Esper, 1794) & & & & & & & & & & & \\
\hline Turbinaria reniformis & Bernard, 1896 & & & & & & & & & & & \\
\hline Turbinaria stellulata & (Lamarck, 1816) & & & & & 1 & 1 & 1 & 1 & 1 & & 1 \\
\hline
\end{tabular}

\section{Euphyllidae}

\begin{tabular}{l|l|l|l|l|l|l|l|l|l|l|l|l|l|l|l|l|l}
\hline Euphyllia ancora & Veron and Pichon, 1980 & & & & & & & & & & & & & & & 1 & \\
\hline${\text { Euphyllia } \text { cristata }^{P}}^{\text {Chevalier, } 1971}$ & & & & & & & & & & & & & & & & \\
\hline Euphyllia glabrescens $^{\text {(Chamisso and Eysenhardt, 1821) }}$ & & & & & & & & & & & & & & & & \\
\hline Physogyra lichtensteini & (Milne Edwards and Haime,1851) & 1 & 1 & & & 1 & & 1 & & 1 & 1 & 1 & 1 & & 1 & 1 & \\
\hline Plerogyra sinuosa & (Dana, 1846) & & 1 & & & 1 & & & & & & & & & & 1 & \\
\hline
\end{tabular}

\section{Faviidae}

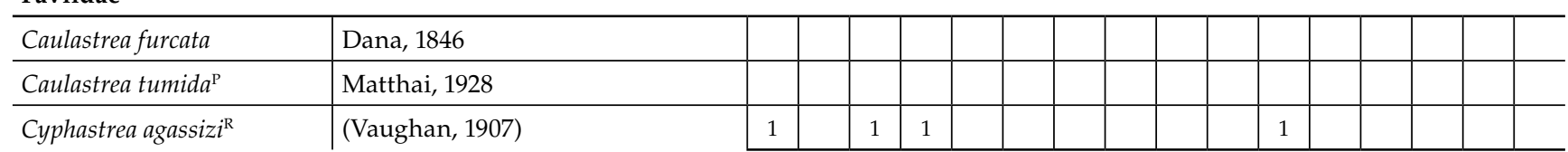




\begin{tabular}{|c|c|c|c|c|c|c|c|c|c|c|c|c|c|c|c|c|c|c|c|c|c|c|c|c|c|c|c|c|}
\hline \multicolumn{14}{|c|}{ South Scott } & \multicolumn{10}{|c|}{ North Scott } & \multicolumn{5}{|c|}{ Seringapatam } \\
\hline 17 & 18 & 19 & 20 & 21 & 22 & 23 & 24 & 25 & 26 & 27 & 28 & 29 & 30 & 31 & 32 & 33 & 34 & 35 & 36 & 37 & 38 & 39 & 40 & 41 & 42 & 43 & 44 & 45 \\
\hline 1 & & & & & & & & & & & 1 & & 1 & & & & 1 & & & & & & & & & & & 1 \\
\hline & & & & & & & & & & & & & & & & & & & & & & & & & & & & \\
\hline \multirow[t]{6}{*}{1} & 1 & 1 & 1 & 1 & & 1 & & 1 & 1 & & 1 & 1 & 1 & 1 & & & & 1 & 1 & & 1 & & 1 & & 1 & & & 1 \\
\hline & & 1 & & & & & 1 & & 1 & & & 1 & & & & & & & & & & & & & & 1 & & \\
\hline & & & & & & & & & & & & & & & & & & & & & & & & & & & & \\
\hline & 1 & & & & & & & & & & & 1 & & & & & & & & & & & & & & & & \\
\hline & & 1 & & & & & 1 & 1 & & & & 1 & & & & 1 & & & & & & & & & & & & \\
\hline & & & & & & 1 & & & & & & 1 & & & & & & & & & & & & & & & & \\
\hline & & & & & & & & & & & & & & & & & & & & & & & & & & & & \\
\hline 1 & 1 & 1 & 1 & 1 & 1 & & 1 & 1 & & & 1 & 1 & & & & 1 & 1 & & & & 1 & 1 & & 1 & 1 & & 1 & \\
\hline \multirow[t]{14}{*}{1} & & 1 & & & & & & & & & 1 & & 1 & & & & & & 1 & & 1 & & 1 & 1 & & & & 1 \\
\hline & & & 1 & & & & & & & & & & & & & & & & & & & & & & & & & 1 \\
\hline & & & & & & & & & & & & & & & & & 1 & & & & & & & & & & & 1 \\
\hline & & & & & & & & & & & & & 1 & 1 & & & 1 & & & & & & & 1 & & & & \\
\hline & 1 & & & & & & & & & & 1 & 1 & 1 & 1 & 1 & & 1 & & & & 1 & & & 1 & & & & 1 \\
\hline & 1 & & 1 & & & 1 & & & 1 & & 1 & & 1 & 1 & & & 1 & & 1 & & 1 & & & 1 & & & & 1 \\
\hline & & & & & & & & & & & & 1 & & & & & & & & & 1 & & & & 1 & & & \\
\hline & 1 & & & & 1 & & & & 1 & & & 1 & 1 & 1 & & & 1 & & 1 & & & & & & & & & \\
\hline & & & & & & & & & & & & & & 1 & & & & & & & & & & & & & & \\
\hline & 1 & 1 & 1 & & & & & & 1 & & & 1 & & 1 & & & & & & & 1 & 1 & & & 1 & 1 & & 1 \\
\hline & 1 & & & & 1 & 1 & & & 1 & & 1 & 1 & 1 & & 1 & & 1 & & 1 & & 1 & 1 & & 1 & & & & 1 \\
\hline & & & & & & & & & & & & & & & & & & & & & 1 & & & & 1 & & & \\
\hline & & & & & & & & & & & & & & & & & & & & & & & & & & & & \\
\hline & & & & & & & & & 1 & & & & & & & & & & & & . & 1 & & & 1 & 1 & & \\
\hline 1 & 1 & 1 & & & 1 & & & & 1 & & & & 1 & & & & 1 & & 1 & & 1 & & 1 & & & & & 1 \\
\hline \multirow[t]{2}{*}{1} & 1 & & & & & 1 & & & 1 & & & 1 & & & & & & 1 & 1 & & 1 & & & & 1 & & & 1 \\
\hline & & & 1 & & & & & 1 & & & & & 1 & 1 & 1 & & 1 & & 1 & & & & & & & & & 1 \\
\hline \multirow[t]{2}{*}{1} & 1 & 1 & 1 & & 1 & 1 & & 1 & 1 & & 1 & 1 & 1 & 1 & & & 1 & 1 & 1 & & 1 & 1 & 1 & 1 & 1 & & & 1 \\
\hline & 1 & & & 1 & & & 1 & & & & & & & & & & & & & & & 1 & & & 1 & & & \\
\hline & & & & & & & & & & & & & & & & & & & & & & & & & & & & \\
\hline \multirow[t]{2}{*}{1} & 1 & & 1 & & & & & & 1 & & 1 & 1 & & 1 & & & 1 & & 1 & & & & & 1 & & & & \\
\hline & 1 & & & & & 1 & & & 1 & & & 1 & & 1 & & & 1 & & & & 1 & & & & & & & \\
\hline
\end{tabular}

\begin{tabular}{l|l|l|l|l|l|l|l|l|l|l|l|l|l|l|l|l|l|l|l|l|l|l|l|l|l|l|l|l}
\hline & 1 & 1 & & & & & & & & & & & & & 1 & & 1 & & & & & & & & & 1 & & 1 \\
\hline & & & & & & & & & & & & & & & & & & & & & & & & & & & & \\
\hline & & & & & & & & & & & & & & & & & & & & & & & & & & & & \\
\hline 1 & & 1 & 1 & & 1 & & & & & & 1 & 1 & & 1 & & & 1 & & 1 & & & & & & & & & 1 \\
\hline & & 1 & 1 & & & & & & & & & 1 & & & & & 1 & & 1 & & & 1 & & 1 & 1 & & & 1 \\
\hline
\end{tabular}

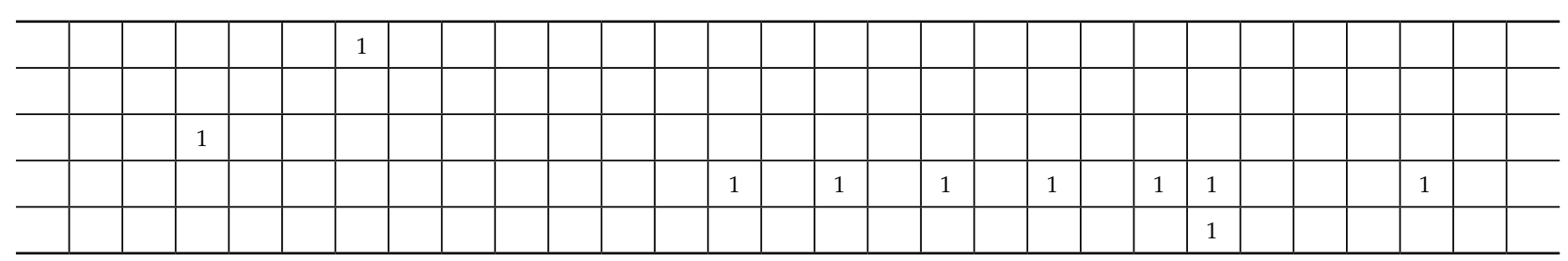

\begin{tabular}{l|l|l|l|l|l|l|l|l|l|l|l|l|l|l|l|l|l|l|l|l|l|l|l|l|l|l|l|l}
\hline & & & & & & & & & 1 & & & 1 & & & & & & & & & & & & & & & & \\
\hline & & & & & & & & & & & & & & & & & & & & & & & & & & & & \\
\hline & & & & & & & 1 & & & & & & & & & & & & & & & & & & & & \\
\hline
\end{tabular}




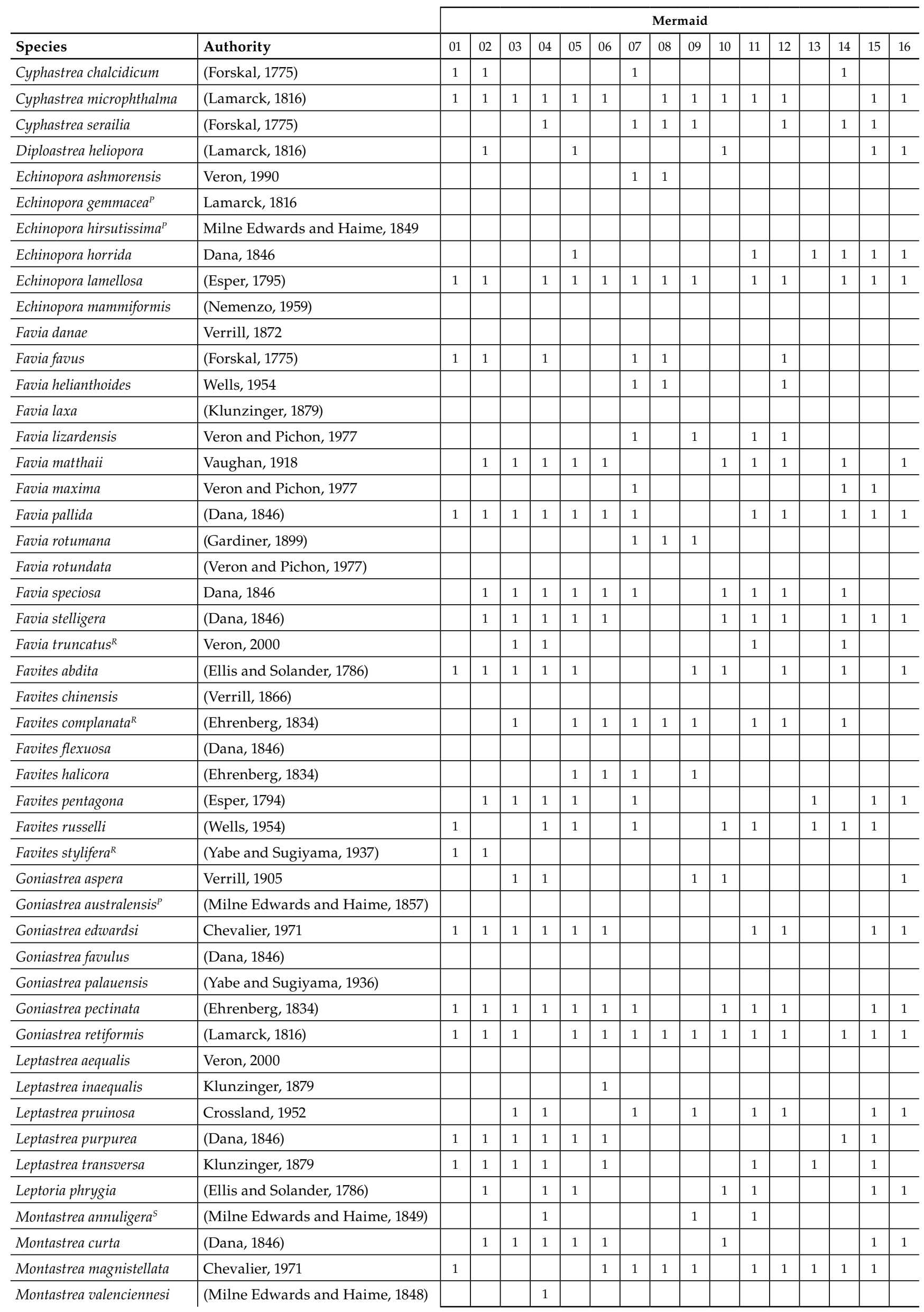




\begin{tabular}{|c|c|c|c|c|c|c|c|c|c|c|c|c|c|c|c|c|c|c|c|c|c|c|c|c|c|c|c|c|c|}
\hline \multicolumn{15}{|c|}{ South Scott } & \multicolumn{10}{|c|}{ North Scott } & \multicolumn{5}{|c|}{ Seringapatam } \\
\hline 17 & 18 & 19 & 20 & 21 & 22 & 23 & 24 & 25 & 26 & 2 & & & 29 & 30 & 31 & 32 & 33 & 34 & 35 & 36 & 37 & 38 & 39 & 40 & 41 & 42 & 43 & 44 & 45 \\
\hline & & & & 1 & & 1 & 1 & 1 & 1 & & & & 1 & 1 & & & 1 & 1 & 1 & & & 1 & 1 & & 1 & 1 & & 1 & \\
\hline & 1 & & & 1 & 1 & 1 & 1 & & 1 & 1 & & & 1 & 1 & 1 & 1 & & 1 & & 1 & & 1 & 1 & & & 1 & & & 1 \\
\hline & 1 & & & & & & & & 1 & 1 & & & 1 & & & 1 & & & & 1 & & & & & & & & & 1 \\
\hline & & & & & & & & & & & & & 1 & & & & & & & 1 & & & & & & & & & 1 \\
\hline & & & & & & & & & & & & & & & & 1 & & & & & & & & & & 1 & & & \\
\hline & & & & & & & & & & & & & & & & & & & & & & & & & & & & & \\
\hline & & & & & & & & & & & & & & & & & & & & & & & & & & & & & \\
\hline 1 & 1 & & & & & 1 & & 1 & 1 & & & & 1 & & & & & 1 & & & & & & & & 1 & & & 1 \\
\hline \multirow[t]{7}{*}{1} & 1 & 1 & 1 & & 1 & 1 & & & 1 & & & & 1 & 1 & 1 & 1 & & 1 & & 1 & & 1 & 1 & & 1 & & & & 1 \\
\hline & 1 & & & & 1 & & & & 1 & & & & & & 1 & & & & & & & & & & & 1 & 1 & & \\
\hline & & & & & & & & & & & & & & & 1 & 1 & & & & & & & & & & & & & \\
\hline & & & & & & & & & 1 & & & & 1 & & & 1 & & & & & & 1 & 1 & & & 1 & 1 & & \\
\hline & & & & & & & & & & 1 & & & & & & 1 & & & & & & 1 & 1 & & & & & & \\
\hline & & & 1 & & & & & & & & & & & & & & & & & & & & & & & & & & \\
\hline & & & 1 & & & 1 & & & & & & & & & & 1 & & & & & & & & & & & & & \\
\hline \multirow[t]{2}{*}{1} & 1 & 1 & 1 & & 1 & & & 1 & 1 & & & & 1 & 1 & 1 & 1 & & 1 & & 1 & & 1 & 1 & 1 & 1 & & 1 & & 1 \\
\hline & & & & & & & & & & & & & & & & & & & & & & & & & & 1 & & & \\
\hline \multirow[t]{4}{*}{1} & & 1 & 1 & 1 & 1 & 1 & 1 & 1 & 1 & & & & 1 & 1 & & & & 1 & & 1 & & 1 & & & 1 & 1 & & & 1 \\
\hline & & & & & & & & & & & & & & & & & & & & & & & & & & & & & \\
\hline & 1 & & & & & & & & & & & & & & & & & & & & & & & & & & & & \\
\hline & 1 & 1 & 1 & 1 & 1 & 1 & 1 & 1 & 1 & & & & 1 & & 1 & & & & & & & 1 & & & & 1 & 1 & & \\
\hline \multirow[t]{2}{*}{1} & 1 & 1 & 1 & & 1 & 1 & & 1 & 1 & & & & 1 & 1 & 1 & 1 & & 1 & & 1 & & 1 & & & 1 & & & & 1 \\
\hline & & & & & & & 1 & & & 1 & & & & & & 1 & & & & & & & & & & & & & \\
\hline \multirow[t]{5}{*}{1} & 1 & 1 & 1 & & 1 & 1 & & 1 & 1 & & & & 1 & 1 & 1 & 1 & & 1 & & 1 & & 1 & & 1 & 1 & & 1 & & 1 \\
\hline & & & & 1 & 1 & & & & & & & & & & & & & & & & & & & & & & & & \\
\hline & & & 1 & . & 1 & 1 & 1 & 1 & 1 & & & & 1 & 1 & 1 & 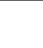 & & & & & & 1 & . & 1 & & 1 & 1 & 1 & 1 \\
\hline & & & & 1 & & & & & & & & & 1 & & 1 & & & & & & & & 1 & & & & & & \\
\hline & 1 & & & & & & & 1 & 1 & 1 & & & & & & 1 & 1 & & & 1 & & & & & & & & 1 & \\
\hline \multirow[t]{2}{*}{1} & 1 & & 1 & & & 1 & & & 1 & & & & & & 1 & 1 & & & & & & 1 & & & & & & & 1 \\
\hline & 1 & 1 & & & 1 & & & & 1 & & & & 1 & & 1 & & & 1 & & & & 1 & & & 1 & & 1 & & 1 \\
\hline 1 & 1 & 1 & 1 & & 1 & 1 & & & 1 & & & & 1 & 1 & 1 & & & 1 & & 1 & & & & & 1 & & & & 1 \\
\hline & 1 & & 1 & 1 & & & 1 & & & 1 & & & & & & & 1 & & & & & & & & & & & 1 & \\
\hline & & & & & & & & & & & & & & & & & & & & & & & & & & & & & \\
\hline & 1 & & & 1 & 1 & & & 1 & 1 & & & & 1 & & & & & 1 & & 1 & & & & & & & & & 1 \\
\hline & 1 & & & & & 1 & & & 1 & & & & & & 1 & & & & & & & 1 & & & & & 1 & & \\
\hline 1 & & & & & & & & & & & & & & & & & & & & & & & & & & & & & \\
\hline 1 & 1 & 1 & 1 & 1 & 1 & 1 & & 1 & 1 & & & & 1 & 1 & 1 & 1 & & 1 & & 1 & & 1 & 1 & & 1 & 1 & 1 & & 1 \\
\hline 1 & 1 & 1 & 1 & 1 & 1 & 1 & & 1 & 1 & & & & 1 & 1 & 1 & & & 1 & & 1 & & 1 & & & 1 & & & & 1 \\
\hline 1 & & & & & & & & & & & & & 1 & & 1 & & & 1 & & 1 & & 1 & & & 1 & & & & 1 \\
\hline & & & & & & 1 & & & & 1 & & & & & & & 1 & & & & & & & & & & & & \\
\hline 1 & 1 & 1 & 1 & & & 1 & & & 1 & & & & & 1 & 1 & & & & & & & & & & & & & & \\
\hline & & & & & 1 & 1 & & 1 & & & & & & 1 & 1 & & & 1 & & 1 & & 1 & & & 1 & 1 & & & 1 \\
\hline & & 1 & 1 & & 1 & 1 & 1 & & 1 & 1 & & & 1 & 1 & 1 & & & 1 & & 1 & & 1 & 1 & & & & & & 1 \\
\hline 1 & 1 & 1 & 1 & & 1 & & & 1 & & & & & & & 1 & 1 & & 1 & & & & & & & & 1 & 1 & & 1 \\
\hline & & & & & & & & & & & & & & & 1 & & & & & & & 1 & & & & & & & \\
\hline 1 & 1 & 1 & 1 & & & 1 & & 1 & 1 & & & & 1 & 1 & 1 & & & 1 & & 1 & & 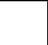 & & 1 & 1 & & & & 1 \\
\hline & 1 & 1 & 1 & & 1 & 1 & & 1 & 1 & & & & 1 & 1 & & 1 & & 1 & & & & 1 & 1 & & & 1 & 1 & & \\
\hline & 1 & & & & & & & & & & & & & 1 & & & & & & & & & & & & & & & \\
\hline
\end{tabular}




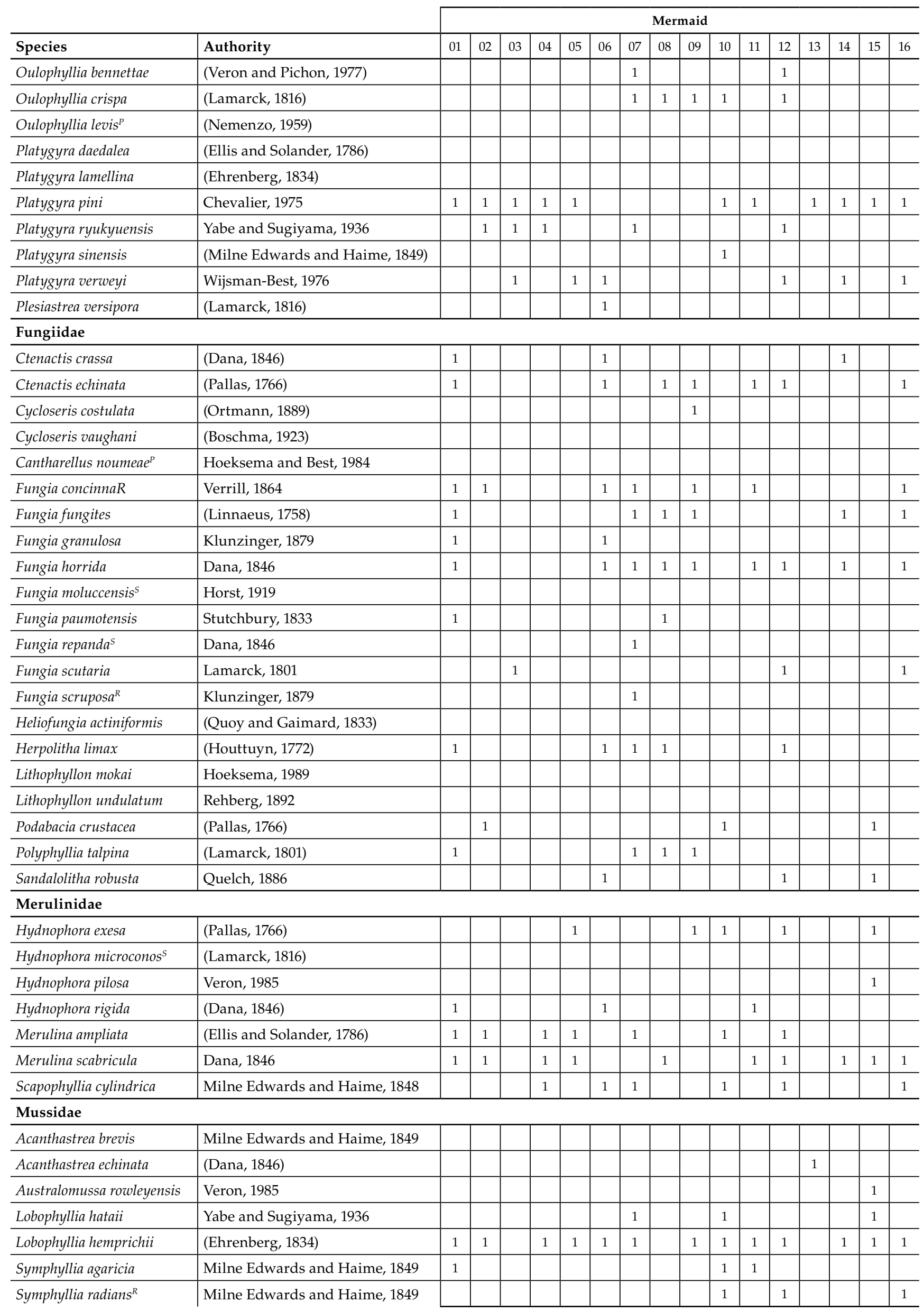




\begin{tabular}{|c|c|c|c|c|c|c|c|c|c|c|c|c|c|c|c|c|c|c|c|c|c|c|c|c|c|c|c|c|}
\hline \multicolumn{14}{|c|}{ South Scott } & \multicolumn{10}{|c|}{ North Scott } & \multicolumn{5}{|c|}{ Seringapatam } \\
\hline 17 & 18 & 19 & 20 & 21 & 22 & 23 & 24 & 25 & 26 & 27 & 28 & 29 & 30 & 31 & 32 & 33 & 34 & 35 & 36 & 37 & 38 & 39 & 40 & 41 & 42 & 43 & 44 & 45 \\
\hline & & & & & & & & & & & & & & & & & & & & & & & & & & 1 & & \\
\hline & & & & & & & & & & & & & & & & & & & & & & & & & & & & \\
\hline & & & & & & & & & & & & & & & & & & & & & & & & & & & & \\
\hline \multirow[t]{7}{*}{1} & 1 & 1 & 1 & & 1 & & & & & & 1 & 1 & 1 & & & & & & & & & & & & & & & 1 \\
\hline & & & & & & 1 & 1 & & & & & & & & & & & & & & & & & & & 1 & & \\
\hline & 1 & 1 & 1 & 1 & 1 & 1 & & & 1 & & 1 & 1 & 1 & & 1 & & 1 & & 1 & & 1 & & & & & & & 1 \\
\hline & & 1 & 1 & & 1 & & & & & & & & 1 & & & 1 & & & & & & & & & & & & \\
\hline & & & & & & & & & & & & & & & & & & & & & & & & 1 & & & & \\
\hline & & 1 & 1 & & & & & & 1 & & 1 & & & & & & & & & & & & & & & & & \\
\hline & & & & & & & & & & & 1 & 1 & & 1 & & 1 & & & 1 & & & & & & & & & \\
\hline & & & & & & & & & & & & & & & & & & & & & & & & & & & & \\
\hline \multirow[t]{6}{*}{1} & & & & & 1 & & & 1 & 1 & & 1 & 1 & 1 & & 1 & & & & & & & 1 & & & & 1 & & \\
\hline & & & & & & & & 1 & 1 & & & 1 & 1 & 1 & & & 1 & & 1 & & 1 & 1 & & & 1 & & & \\
\hline & & & & & & & & & & & & & & & & & & & & & & & & & & & & \\
\hline & & & & & & & & & & & & & & & & & & & 1 & & & & & & & & & \\
\hline & & & & & & & & & & & & & & & & & & & & & & & & & & & & \\
\hline & & & & 1 & 1 & & & 1 & 1 & & & 1 & 1 & & 1 & & 1 & & & & 1 & 1 & & & & 1 & & \\
\hline 1 & 1 & & & 1 & . & & & 1 & 1 & & & & & 1 & 1 & & 1 & & 1 & & 1 & 1 & & & & & & 1 \\
\hline 1 & 1 & & & & 1 & & & 1 & 1 & & 1 & & 1 & & 1 & & 1 & & & & . & & & & 1 & & & \\
\hline \multirow[t]{13}{*}{1} & & & 1 & & & & & 1 & 1 & & 1 & 1 & 1 & 1 & 1 & & & & & & 1 & 1 & & & 1 & & & \\
\hline & & & & & & & & 1 & & & & & & & & & & & & & 1 & & & & & & & \\
\hline & & & & & & & & & 1 & & & 1 & & & & & & & & & 1 & 1 & & & & & & \\
\hline & & & & & 1 & & & 1 & & & & & & & 1 & & & & & & & 1 & & & & & & 1 \\
\hline & & & & & & & & & & & & 1 & & & & & & & & & & & & & & & & \\
\hline & & & & & 1 & & & & & & & & & & & & & & & & & 1 & & & & & & \\
\hline & & & & & & & & & & & & & & & & & & & & & & & & & & 1 & & \\
\hline & 1 & & & & & & & 1 & 1 & & & & & & 1 & & & & & & 1 & 1 & & & 1 & 1 & & \\
\hline & & & & & & & & & 1 & & & & & & 1 & & & & & & & & & & & 1 & & \\
\hline & & 1 & 1 & & 1 & 1 & & 1 & 1 & & 1 & 1 & 1 & 1 & 1 & & 1 & & 1 & & 1 & 1 & 1 & & 1 & 1 & & 1 \\
\hline & & & & & & 1 & & & & & & & 1 & & 1 & & 1 & & & & 1 & 1 & & & 1 & 1 & & 1 \\
\hline & & & & & & & & & & & & & & & & & & & & & & 1 & & & 1 & & & \\
\hline & 1 & & & & 1 & 1 & & 1 & 1 & & & 1 & & & 1 & & 1 & & & & 1 & 1 & & & 1 & 1 & & 1 \\
\hline
\end{tabular}

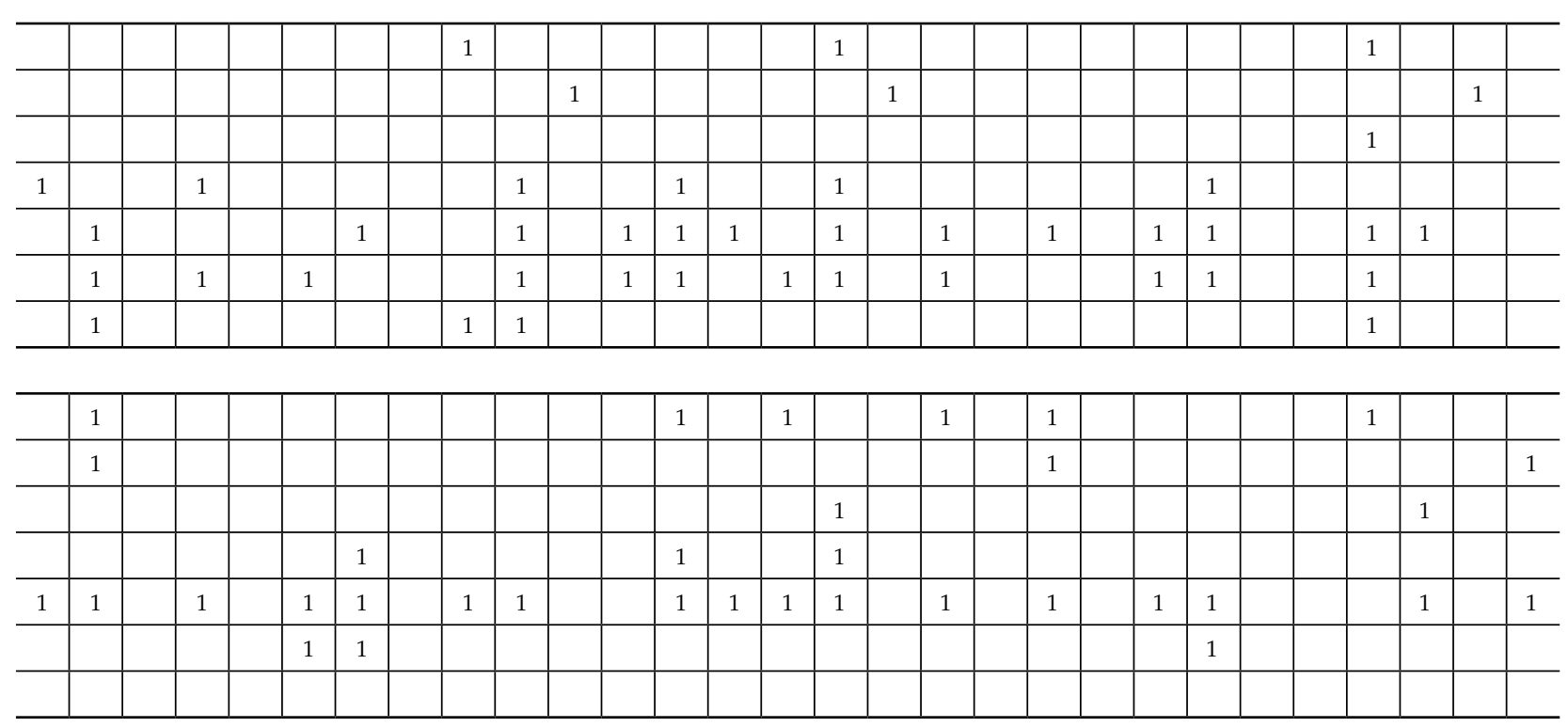




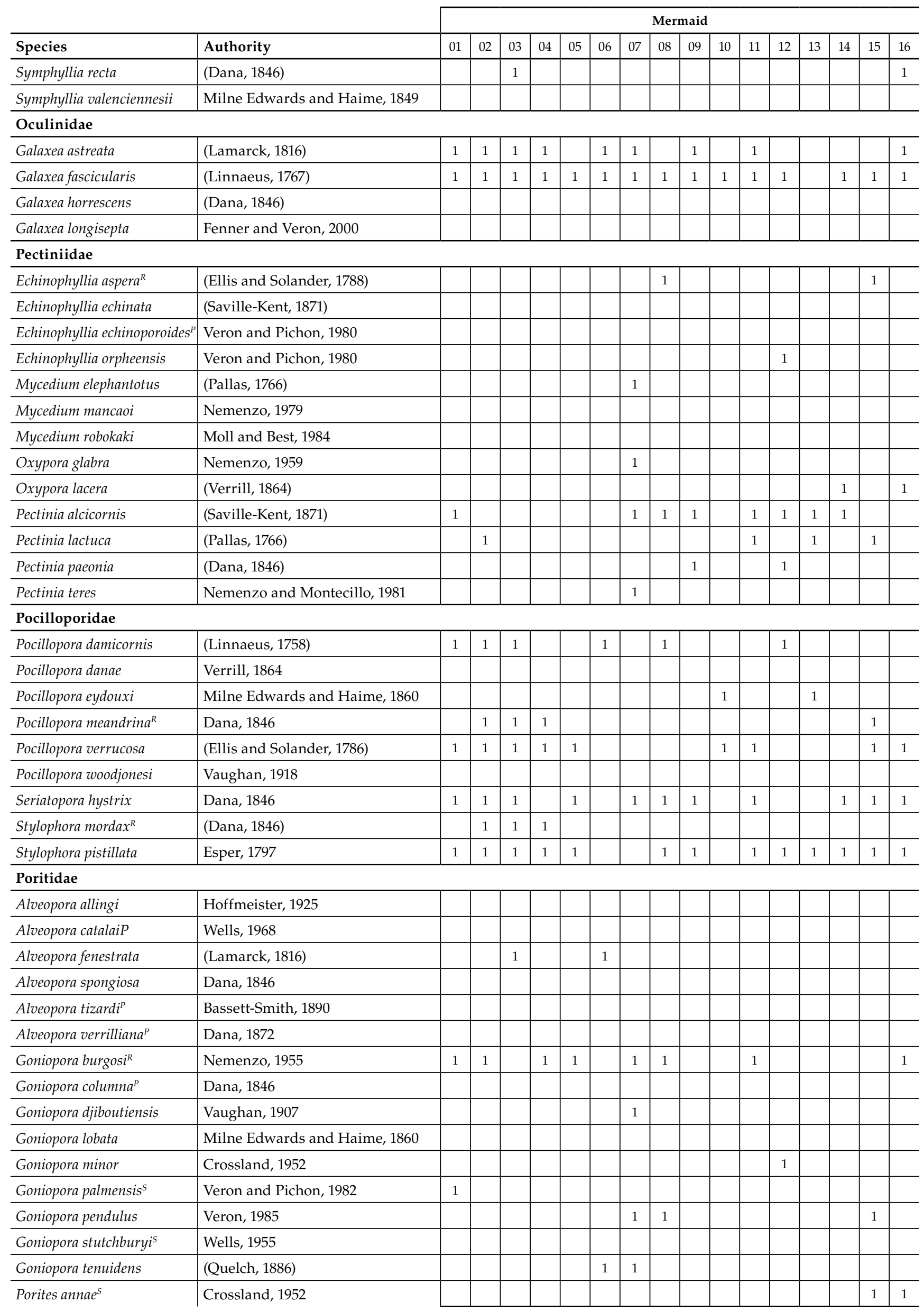




\begin{tabular}{|c|c|c|c|c|c|c|c|c|c|c|c|c|c|c|c|c|c|c|c|c|c|c|c|c|c|c|c|c|}
\hline \multicolumn{14}{|c|}{ South Scott } & \multicolumn{10}{|c|}{ North Scott } & \multicolumn{5}{|c|}{ Seringapatam } \\
\hline \multirow[t]{3}{*}{17} & 18 & 19 & 20 & 21 & 22 & 23 & 24 & 25 & 26 & 27 & 28 & 29 & 30 & 31 & 32 & 33 & 34 & 35 & 36 & 37 & 38 & 39 & 40 & 41 & 42 & 43 & 44 & 45 \\
\hline & & & & & & & & & 1 & & & & & & & & & & & & & & & & & 1 & 1 & \\
\hline & & & & & & 1 & & & & & & & & & 1 & & & & & & & & & & & & & \\
\hline & & & & & & & & & & & & & & & & & & & & & & & & & & & & \\
\hline 1 & & & 1 & & 1 & 1 & & & 1 & & 1 & 1 & 1 & 1 & & & 1 & & 1 & & 1 & 1 & & 1 & & 1 & & 1 \\
\hline \multirow[t]{17}{*}{1} & 1 & 1 & 1 & & 1 & 1 & & 1 & 1 & & 1 & 1 & 1 & 1 & 1 & & 1 & & 1 & & 1 & 1 & 1 & 1 & 1 & 1 & & 1 \\
\hline & & & & & & & & & 1 & & & 1 & & & & & & & & & & & & & & & & \\
\hline & 1 & & & & & & & & 1 & & & & & & & & & & & & & & & & & & & \\
\hline & & & & & & & & & & & & & & & & & & & & & & & & & & & & \\
\hline & & & & & & & & & & & & & & & 1 & & & & & & & 1 & & & 1 & 1 & & \\
\hline & & & & & & & & & & & & & & & & & & & & & & & & & 1 & 1 & & \\
\hline & & & & & & & & & & & & & & & & & & & & & & & & & & & & \\
\hline & & & & & & & & & 1 & & & 1 & & & 1 & & & & & & & 1 & & & 1 & 1 & & \\
\hline & 1 & & & & 1 & 1 & & 1 & 1 & & & 1 & 1 & & & & 1 & & & & 1 & & & & & & & \\
\hline & 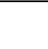 & & & & & & & & 1 & & & 1 & 1 & & & & & & & & & 1 & & & & & & \\
\hline & 1 & & & & & & & 1 & & & & & & & & & & & & & 1 & 1 & & & & & & \\
\hline & & & & & & & & & & & & & & & & & & & & & 1 & 1 & & & & & & \\
\hline & 1 & & 1 & & & & & & & & & 1 & 1 & & 1 & & 1 & & 1 & & 1 & & & & & & & \\
\hline & & & & & 1 & 1 & & 1 & 1 & & & 1 & & & 1 & & & & 1 & & & 1 & & & 1 & 1 & & \\
\hline & & & & & 1 & & & & 1 & & & 1 & 1 & 1 & & & & & & & 1 & & & & & & & \\
\hline & & & & & & 1 & & & & & & & & & 1 & & & & & & 1 & & & & 1 & 1 & & \\
\hline & & & & & & & & & & & & 1 & & & & & & & & & & & & & 1 & & & \\
\hline \multirow{3}{*}{1} & & & & & & & & & & & & & & & & & & & & & & & & & & & & \\
\hline & 1 & 1 & 1 & 1 & 1 & 1 & 1 & 1 & 1 & 1 & 1 & 1 & 1 & 1 & 1 & 1 & 1 & & 1 & & 1 & & & 1 & 1 & 1 & 1 & 1 \\
\hline & & & & & & & & & & & & & & & & 1 & 1 & & 1 & & & & & & & & & \\
\hline \multirow[t]{2}{*}{1} & & 1 & 1 & & 1 & 1 & & & 1 & & 1 & & & & & 1 & 1 & & 1 & & & & 1 & 1 & & & & 1 \\
\hline & & & & & & & & & & & & 1 & & & & & 1 & & 1 & 1 & & & 1 & 1 & & & 1 & 1 \\
\hline \multirow[t]{4}{*}{1} & 1 & 1 & 1 & & 1 & 1 & & 1 & 1 & & 1 & 1 & 1 & 1 & & & 1 & & 1 & & & & 1 & 1 & & & & 1 \\
\hline & & & & & & & & & & & & & & & & & 1 & & & & & & 1 & & & & & \\
\hline & 1 & & & 1 & 1 & & 1 & 1 & 1 & & & 1 & 1 & 1 & 1 & & 1 & 1 & & & 1 & 1 & & 1 & & & & 1 \\
\hline & & & & 1 & & & & & & & & & & & & & 1 & & & & & & & & & & & \\
\hline 1 & 1 & 1 & 1 & 1 & 1 & & 1 & 1 & 1 & & & 1 & & 1 & & & 1 & & & & & & & & 1 & & & 1 \\
\hline
\end{tabular}

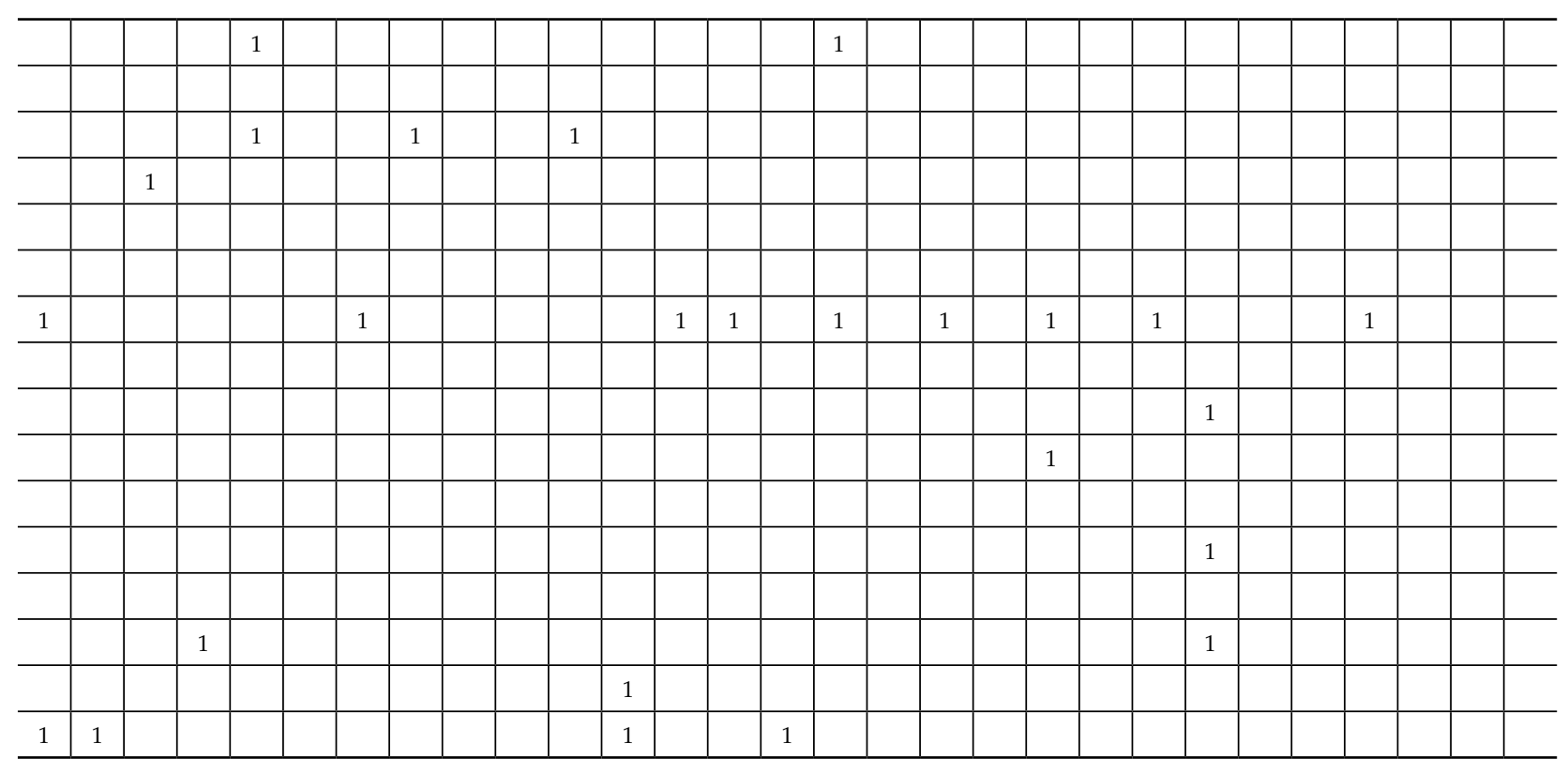




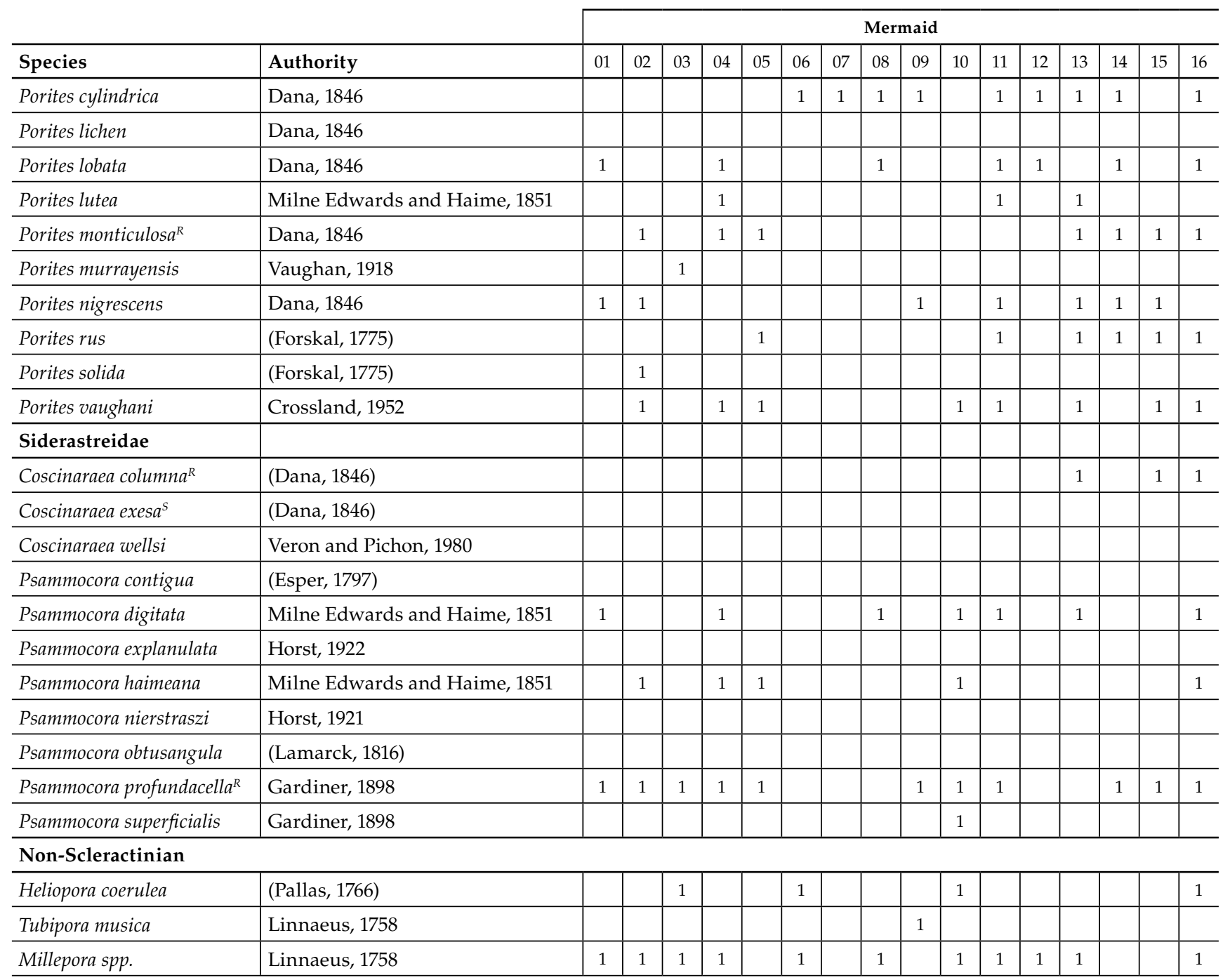




\begin{tabular}{|c|c|c|c|c|c|c|c|c|c|c|c|c|c|c|c|c|c|c|c|c|c|c|c|c|c|c|c|c|}
\hline \multicolumn{14}{|c|}{ South Scott } & \multicolumn{10}{|c|}{ North Scott } & \multicolumn{5}{|c|}{ Seringapatam } \\
\hline 17 & 18 & 19 & 20 & 21 & 22 & 23 & 24 & 25 & 26 & 27 & 28 & 29 & 30 & 31 & 32 & 33 & 34 & 35 & 36 & 37 & 38 & 39 & 40 & 41 & 42 & 43 & 44 & 45 \\
\hline 1 & 1 & & 1 & 1 & & & 1 & & & & & 1 & & & 1 & & 1 & & & & 1 & 1 & & & 1 & 1 & & 1 \\
\hline \multicolumn{29}{|l|}{1} \\
\hline \multirow[t]{4}{*}{1} & 1 & & & 1 & & 1 & & 1 & 1 & & 1 & & 1 & 1 & 1 & 1 & & & 1 & 1 & 1 & 1 & 1 & & & & & \\
\hline & 1 & 1 & & & & & & & 1 & 1 & & & 1 & 1 & & & 1 & 1 & & 1 & & & & & & & & \\
\hline & & 1 & & & 1 & & & & & & 1 & 1 & 1 & 1 & & & & & & & 1 & 1 & & & & 1 & & 1 \\
\hline & 1 & 1 & & & & & 1 & & & & 1 & & 1 & 1 & & & & & & & & & & & & & & \\
\hline \multirow[t]{2}{*}{1} & 1 & 1 & 1 & 1 & 1 & & & & & & 1 & 1 & & & & & 1 & & 1 & & & & & & 1 & & & \\
\hline & 1 & 1 & & & & & & & & & 1 & & 1 & 1 & & & 1 & & & & 1 & & & 1 & & 1 & & \\
\hline 1 & & & 1 & & & & & & & 1 & 1 & & & & & 1 & & & 1 & & & & 1 & & & & & \\
\hline 1 & 1 & 1 & 1 & & 1 & & & & & & 1 & & & & & & 1 & & 1 & & 1 & & & 1 & & & & 1 \\
\hline & & & & & & & & & & & & & & & & & & & & & & & & & & & & \\
\hline 1 & & & & & & & & & & & 1 & 1 & 1 & & & & 1 & & 1 & & 1 & & & & & & & \\
\hline \multirow[t]{8}{*}{1} & 1 & & & & & & & & & & 1 & & 1 & & & & & & & & & & & & 1 & & & \\
\hline & 1 & & & & & & & 1 & 1 & & & 1 & 1 & 1 & & & 1 & & & & 1 & & & & & & & 1 \\
\hline & & 1 & & 1 & & & & & & 1 & & & & & & & & & & & & & & & & & & \\
\hline & & 1 & & & & & & & & & & & & & & 1 & 1 & & & & & & & 1 & & & & 1 \\
\hline & & & & & & & & & & & & & & & & & & & 1 & & & & & & & & & \\
\hline & 1 & & & & & & & & & & 1 & 1 & & & & & & & & & 1 & & 1 & & & & & 1 \\
\hline & & 1 & & & & & & & & & & 1 & 1 & & & & & & & & & & & & & & & \\
\hline & & & & 1 & & & 1 & & & 1 & & & & & & & & & & & & & & & & & & \\
\hline \multirow[t]{2}{*}{1} & & 1 & 1 & & 1 & & & 1 & 1 & 1 & 1 & 1 & 1 & 1 & & 1 & 1 & 1 & 1 & & 1 & & 1 & & & & & 1 \\
\hline & & & & & & 1 & & & 1 & & & 1 & 1 & 1 & & & 1 & & & & 1 & & & 1 & & & & 1 \\
\hline \multirow{3}{*}{1} & & & & & & & & & & & & & & & & & & & & & & & & & & & & \\
\hline & 1 & 1 & 1 & & 1 & 1 & & & & & 1 & 1 & 1 & & & 1 & 1 & & 1 & & & 1 & & 1 & & & 1 & 1 \\
\hline & 1 & & & & & & & & & & & & & & & & & & & & & & & & & & & \\
\hline 1 & 1 & 1 & 1 & & 1 & 1 & & 1 & 1 & & 1 & 1 & 1 & 1 & 1 & & 1 & & & & 1 & 1 & & & 1 & & & 1 \\
\hline
\end{tabular}

\begin{tabular}{l|l|l|l|l|l|l|l|l|l|l|l|l|l|l|l|l|l|l|l|l|l|l|l|l|l|l|l|l}
\hline 74 & 105 & 74 & 78 & 30 & 66 & 71 & 27 & 65 & 109 & 0 & 74 & 116 & 86 & 79 & 74 & 20 & 100 & 10 & 83 & 7 & 89 & 68 & 29 & 47 & 67 & 54 & 13 & 88 \\
\hline
\end{tabular} 
Table 2 Station richness and transect ratios for 41 stations at Mermaid, South Scott, North Scott, and Seringapatam Reefs.

\begin{tabular}{|c|c|c|c|c|}
\hline Station Richness & Mermaid & South Scott & North Scott & Seringapatam \\
\hline Mean & 69.500 & 76.462 & 60.000 & 54.600 \\
\hline Standard Error & 2.633 & 7.611 & 12.407 & 12.663 \\
\hline Standard Deviation & 9.851 & 27.443 & 37.222 & 28.316 \\
\hline Range & 34 & 91 & 95 & 77 \\
\hline Minimum & 52 & 27 & 6 & 13 \\
\hline Maximum & 86 & 118 & 101 & 90 \\
\hline Count & 14 & 13 & 9 & 5 \\
\hline Station Richness & Reef Front & Lagoon & Reef Flat & All Habitats \\
\hline Mean & 77.188 & 76.833 & 23.143 & 67.805 \\
\hline Standard Error & 3.028 & 4.505 & 6.501 & 4.059 \\
\hline Standard Deviation & 12.112 & 19.113 & 17.199 & 25.993 \\
\hline Range & 53 & 66 & 51 & 112 \\
\hline Minimum & 48 & 52 & 6 & 6 \\
\hline Maximum & 101 & 118 & 57 & 118 \\
\hline Count & 16 & 18 & 7 & 41 \\
\hline Transect Ratio & Reef Front & Lagoon & Reef Flat & All Habitats \\
\hline Mean & 78.799 & 74.354 & 32.333 & 67.001 \\
\hline Standard Error & 3.384 & 3.706 & 3.480 & 4.656 \\
\hline Standard Deviation & 12.200 & 11.119 & 8.524 & 24.638 \\
\hline Range & 47.994 & 29.517 & 23.000 & 93.827 \\
\hline Minimum & 45.833 & 57.692 & 21.000 & 0.000 \\
\hline Maximum & 93.827 & 87.209 & 44.000 & 93.827 \\
\hline Count & 13 & 9 & 6 & 28 \\
\hline
\end{tabular}


Table 3 Analysis of similarities (ANOSIM), two-way crossed, on species presence/absence data.

Tests for differences between reef system groups

(across all Habitat type groups)

Global Test

Sample statistic (Global R): 0.483

Significance level of sample statistic: $0.1 \%$

Number of permutations: 999 (Random sample from a large number)

Number of permuted statistics greater than or equal to Global R: 0

\begin{tabular}{l|c|c|c|c|c}
\hline $\begin{array}{l}\text { Pairwise Tests } \\
\text { Groups }\end{array}$ & $\begin{array}{c}\text { R } \\
\text { Statistic }\end{array}$ & $\begin{array}{c}\text { Significance } \\
\text { Level \% }\end{array}$ & $\begin{array}{c}\text { Possible } \\
\text { Permutations }\end{array}$ & $\begin{array}{c}\text { Actual } \\
\text { Permutations }\end{array}$ & $\begin{array}{c}\text { Number }>= \\
\text { Observed }\end{array}$ \\
\hline Mermaid, South Scott & 0.545 & 0.1 & 1783782 & 999 & 0 \\
Mermaid, North Scott & 0.495 & 0.1 & 36960 & 999 & 0 \\
Mermaid, Seringapatam & 0.657 & 0.3 & 945 & 945 & 3 \\
South Scott, North Scott & 0.344 & 0.7 & 47040 & 999 & 6 \\
South Scott, Seringapatam & 0.59 & 0.7 & 1764 & 999 & 6 \\
North Scott, Seringapatam & 0.181 & 15.8 & 400 & 400 & 63 \\
\hline
\end{tabular}

Tests for differences between habitat type groups

(across all Reef system groups)

Global Test

Sample statistic (Global R): 0.739

Significance level of sample statistic: $0.1 \%$

Number of permutations: 999 (Random sample from a large number)

Number of permuted statistics greater than or equal to Global R: 0

\begin{tabular}{l|c|c|c|c|c}
\hline Pairwise Tests & $\begin{array}{c}\text { R } \\
\text { Groups }\end{array}$ & $\begin{array}{c}\text { Significance } \\
\text { Level \% }\end{array}$ & $\begin{array}{c}\text { Possible } \\
\text { Permutations }\end{array}$ & $\begin{array}{c}\text { Actual } \\
\text { Permutations }\end{array}$ & $\begin{array}{c}\text { Number }>= \\
\text { Observed }\end{array}$ \\
\hline Lagoon, Reef Front & 0.716 & 0.1 & 17837820 & 999 & 0 \\
Lagoon, Reef Flat & 0.865 & 0.1 & 5670 & 999 & 0 \\
Reef Front, Reef Flat & 0.935 & 0.1 & 5040 & 999 & 0 \\
\hline
\end{tabular}




\begin{tabular}{|c|c|c|c|c|c|c|c|c|c|c|c|c|c|c|c|c|c|c|c|c|c|c|}
\hline 누 & - & & & & & & & - & $r$ & - & & & & - & & - & & & & & - & \\
\hline FH & & & & & $r$ & & & $\neg$ & & $-r$ & & & & - & & $r$ & & & - & & & -1 \\
\hline F & & & $r$ & & & & $r$ & & - & & & & -1 & $r$ & $r$ & $r$ & $-r$ & & & & $r$ & \\
\hline 7 & & & & $\neg$ & & & - & & - & & & $r$ & - & & - & - & - & & - & & & \\
\hline F & $r$ & & & & & & & $r$ & & & $r$ & & $\neg$ & $r$ & 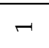 & $r$ & $\neg$ & & $r$ & & & $r$ \\
\hline 와 & & & & & & $r$ & & -1 & & & $r$ & & & $r$ & & $r$ & & & $r$ & & & \\
\hline ले & & & - & & & & $r$ & & & & & - & $-r$ & $r$ & $r$ & - & $-r$ & & - & & & - \\
\hline$\infty$ & & & $r$ & & & & $r$ & & $r$ & & & $r$ & $r$ & $r$ & $r$ & $r$ & & & $r$ & & & $r$ \\
\hline के & & & & & $r$ & & & $\dashv$ & & - & & & & $r$ & & $r$ & & & $r$ & & & $r$ \\
\hline ஜ & $r$ & & & & & & & $r$ & & $\neg$ & & & - & $r$ & $r$ & $r$ & $\neg$ & & & & $r$ & \\
\hline$\stackrel{1}{m}$ & & & & & - & & & $r$ & & $r$ & & $r$ & $\rightarrow$ & & $r$ & $r$ & & & $r$ & & & $r$ \\
\hline ले & -1 & & & & & & & $-r$ & & & & - & $r$ & - & & & $-r$ & & & $-r$ & & $r$ \\
\hline$m$ & & & & & $r$ & & & - & & - & & & & - & & $r$ & & & - & & & $r$ \\
\hline$\tilde{m}$ & & $r$ & $r$ & & & & $r$ & & - & & & $r$ & $r$ & - & - & $r$ & & & - & & & $r$ \\
\hline$\vec{m}$ & - & & & & & & & - & & $r$ & & & & $r$ & $r$ & $r$ & $\neg$ & & & & $\neg$ & \\
\hline m & - & & & & & & & - & & - & & & - & $r$ & - & $r$ & $-r$ & & & & - & \\
\hline ì & & & $r$ & $r$ & & & $r$ & & & & & & $r$ & - & $r$ & $r$ & $r$ & & & $r$ & & $r$ \\
\hline$\stackrel{\sim}{\sim}$ & -1 & & & & & & & -1 & & & $r$ & & & $r$ & & - & - & & & & $\neg$ & \\
\hline$\hat{\mathrm{N}}$ & & & & & $r$ & & & - & & - & & - & $r$ & & & - & & & - & & & - \\
\hline 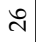 & & $r$ & & $r$ & & & $r$ & & $r$ & & & $r$ & $r$ & $r$ & & $r$ & - & & & & $r$ & \\
\hline$\stackrel{2}{\sim}$ & & & $r$ & & & & $r$ & & - & & & $r$ & $r$ & $r$ & $r$ & $r$ & & & $r$ & & & $r$ \\
\hline 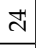 & & & & & $r$ & & & $\neg$ & & $\neg$ & $\rightarrow$ & $\neg$ & - & $r$ & & $\neg$ & & & $r$ & & & $r$ \\
\hline$\ddot{\sim}$ & & & $r$ & & & & $r$ & & - & & & $-r$ & $r$ & $r$ & $r$ & $r$ & - & & $r$ & & & $r$ \\
\hline สี & $-r$ & & & & & & & -1 & & & - & & - & $-r$ & & & $-r$ & & $r$ & & & -1 \\
\hline$\vec{\lambda}$ & & & & & $r$ & & $r$ & & $r$ & & & - & - & - & & - & & & - & & & $-r$ \\
\hline ন & $r$ & & & & & & & - & & & $r$ & & & $r$ & & . & - & & $r$ & & & $r$ \\
\hline 9 & - & & & & & & & -1 & & & $r$ & & & $r$ & & - & $-r$ & & - & & & $r$ \\
\hline$\underset{\mid \infty}{\sim}$ & & $r$ & & & & & & $-r$ & $r$ & $-r$ & & $r$ & - & $r$ & & & - & & & & $r$ & \\
\hline$\therefore$ & $r$ & & & & & & & - & & & $r$ & & & - & & & $r$ & & & & $r$ & \\
\hline 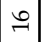 & - & & & & & & & -1 & & & $r$ & & & $r$ & & & - & & & & $r$ & \\
\hline$\stackrel{20}{-1}$ & - & & & & & & & - & & - & - & & & - & $r$ & & - & & & & - & \\
\hline $\mathbb{Z}$ & & - & & & & & $r$ & & $r$ & & & - & - & $r$ & $r$ & $r$ & & & - & & & $r$ \\
\hline$\stackrel{2}{2}$ & & & & & & $r$ & & $r$ & & & $r$ & & $r$ & $r$ & & $r$ & & & & & $r$ & \\
\hline$\approx$ & & & - & & & & $r$ & & & & & & $r$ & $r$ & $r$ & $r$ & $r$ & & $\neg$ & & 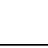 & \\
\hline$\Rightarrow$ & & & $r$ & & & & $r$ & & $r$ & & & $r$ & $r$ & $r$ & $r$ & $r$ & $r$ & & & $r$ & $r$ & \\
\hline 으 & & & & & & - & & - & & & $r$ & & $r$ & - & & - & & & & & $-r$ & \\
\hline 8 & & & - & & & & $r$ & & & & & - & $r$ & - & & $r$ & & & - & & & - \\
\hline$\infty$ & & $r$ & & & & & $r$ & & $r$ & & & $-r$ & $r$ & & $r$ & $r$ & $r$ & & - & & & - \\
\hline$\Delta$ & & & $r$ & & & & $r$ & & $r$ & & & - & $r$ & - & $-r$ & - & - & & - & & & $r$ \\
\hline ๑ & & & & $r$ & & & $r$ & & $r$ & & & $r$ & $r$ & $r$ & $r$ & $r$ & & & $r$ & & & $r$ \\
\hline 12 & $r$ & & & & & & & - & & $r$ & & & & $r$ & & & & $r$ & & & - & \\
\hline 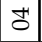 & $r$ & & & & & & & $-r$ & & & - & & & $r$ & - & - & - & - & & & $r$ & \\
\hline 8 & & & & & $r$ & & & $-r$ & & $r$ & & & & $r$ & & $r$ & & & - & & & - \\
\hline ฮี & $r$ & & & & & & & $-r$ & & & $r$ & & & $r$ & & & & $r$ & & & $r$ & \\
\hline 5 & & & $r$ & & & & $r$ & & - & & & - & - & - & $\rightarrow$ & $r$ & & & & - & & $r$ \\
\hline 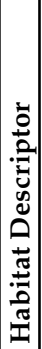 & 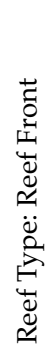 & 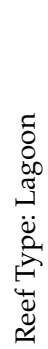 & 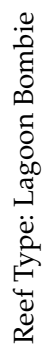 & 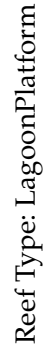 & 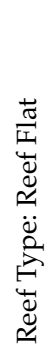 & 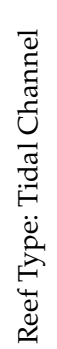 & 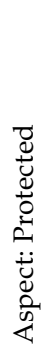 & 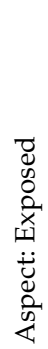 & 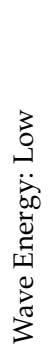 & 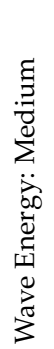 & 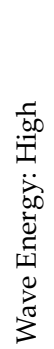 & 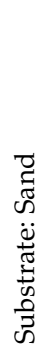 & 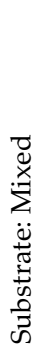 & 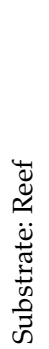 & 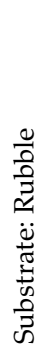 & $\begin{array}{l}\frac{\vec{\sigma}}{\vec{I}} \\
\ddot{0} \\
\frac{\tilde{O}}{\omega}\end{array}$ & 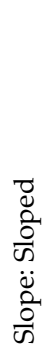 & $\begin{array}{l}\bar{\sigma} \\
3 \\
\ddot{8} \\
\frac{0}{\omega} \\
\frac{0}{\omega}\end{array}$ & 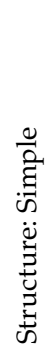 & 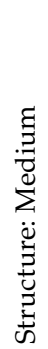 & 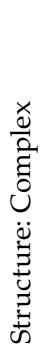 & 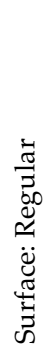 \\
\hline
\end{tabular}




\begin{tabular}{|c|c|c|c|c|c|c|c|c|c|c|c|c|c|c|c|c|c|c|c|c|c|c|c|c|}
\hline- & - & & - & & & & - & & & - & & & & & - & & & & & & & -1 & -1 & \\
\hline & & & & $r$ & & & & $r$ & & & & & & & $r$ & & & & & & 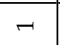 & & 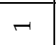 & \\
\hline$r$ & & $r$ & & & $r$ & & & $r$ & $r$ & & & & & & & & & & -7 & & & - & -7 & \\
\hline$r$ & & $r$ & & $r$ & & $r$ & $r$ & & & $r$ & & & & & & & $-r$ & & & & $r$ & & -7 & \\
\hline & $r$ & $r$ & $r$ & & & $r$ & & $r$ & $r$ & & & $r$ & & & & & & & & & & 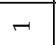 & -7 & \\
\hline$r$ & $r$ & & $r$ & & & $r$ & & & & $r$ & & & & & 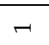 & & & & & $r$ & & & & - \\
\hline & & -7 & & & $r$ & & & $r$ & & & & & $r$ & & & & & & & & & - & 7 & \\
\hline & & $r$ & & & - & & & $\neg$ & & & & & & & - & & & & & & & -7 & $-r$ & \\
\hline & & & & -1 & & & & -1 & & & & & - & & 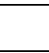 & & & & & & & - & -1 & \\
\hline 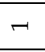 & - & & - & & & - & - & - & -7 & & & & & & -7 & & & & & & & - & - & \\
\hline & & & & $\neg$ & & $\neg$ & $r$ & & -7 & & & & & & & & $r$ & & & & $\rightarrow$ & & -7 & \\
\hline$r$ & $r$ & $\rightarrow$ & $r$ & & & 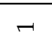 & $r$ & & $r$ & $r$ & & & & & & & $r$ & & & & & 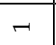 & -7 & \\
\hline & & & & $\neg$ & 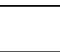 & & & $r$ & -7 & & & $r$ & & & & & & & & & & - & -7 & \\
\hline & & $r$ & 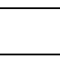 & & $r$ & & 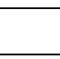 & $r$ & -1 & & & & & & & & $r$ & & & & & - & $\rightarrow$ & \\
\hline-7 & $r$ & 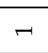 & -7 & & & & -7 & & -7 & & & & & & & & $r$ & & & & & $\rightarrow$ & -7 & \\
\hline$r$ & $r$ & & $r$ & & & & $r$ & 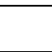 & - & & & & & & - & & 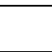 & & & & & $-r$ & $-r$ & \\
\hline & & 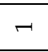 & & & & $r$ & -7 & - & -1 & & & & & & & & $r$ & & & & -1 & 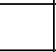 & -1 & \\
\hline-7 & $\neg$ & 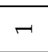 & - & & & $\neg$ & $r$ & & - & $r$ & & & & & & & $r$ & & & & & -7 & $-r$ & \\
\hline & & & & $r$ & & & & $r$ & & & & $r$ & & & & & & & & $r$ & & & & - \\
\hline$r$ & & $r$ & & $r$ & 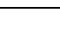 & & $-r$ & & & $r$ & & $\neg$ & & & & & & & & & & $\rightarrow$ & -7 & \\
\hline & & 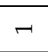 & & & $r$ & $\neg$ & & $\neg$ & & & & -7 & & & & & & & & & & 7 & -7 & \\
\hline & & & & - & & & & $\neg$ & & & & & & - & & & & & & & & $\rightarrow$ & $r$ & \\
\hline$r$ & & $r$ & & & & - & & - & & & & & $r$ & & & & & & & & & -7 & -7 & \\
\hline & $r$ & & - & & & & $r$ & & - & & & & & & & - & & & & & & - & - & \\
\hline & 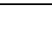 & & & $r$ & & & & $r$ & & & & & & -7 & & & & & & & & -7 & $r$ & \\
\hline & $r$ & & & & & & $r$ & & $r$ & $r$ & & & & 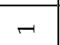 & & & & & & & & 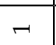 & 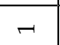 & \\
\hline & - & $r$ & 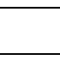 & & & - & & & -1 & $r$ & & & & -1 & & & & & & & & -1 & -1 & \\
\hline$r$ & & - & - & & & & - & & & - & & & & -7 & & & & & & & & $\neg$ & - & \\
\hline-7 & $r$ & & & & & & $r$ & & & $r$ & & $\neg$ & & & & & & & & & & $\neg$ & -7 & \\
\hline-1 & $r$ & & $r$ & & & & -7 & & & - & & & & $r$ & & & & & & & & $\neg$ & -1 & \\
\hline$r$ & $r$ & & - & & & & - & & & $r$ & & & $r$ & & & & & & & & & $\neg$ & - & \\
\hline 7 & 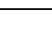 & -1 & 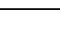 & & $r$ & & 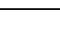 & $r$ & -7 & & & $r$ & & & & & & & & & & - & -7 & \\
\hline$\tau$ & 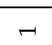 & & $r$ & & & & 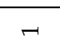 & & & $r$ & & & & & $\pi$ & & & & & 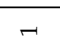 & & 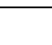 & & 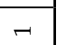 \\
\hline-1 & & $r$ & & & $r$ & $r$ & & $r$ & -1 & & & & & & & & & & $r$ & & & 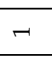 & -7 & \\
\hline- & & $r$ & & & $r$ & & & - & - & & & & & & - & & & & & & & - & - & \\
\hline$r$ & $r$ & & $r$ & & & & $r$ & 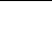 & & $r$ & & & & & 7 & & & & & $r$ & & 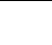 & 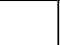 & 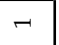 \\
\hline & & & & & & 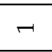 & & - & -1 & & -7 & & & & & & & & & & & $\neg$ & -7 & \\
\hline & & - & & & $r$ & 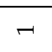 & & $r$ & & & & $r$ & & & & & & & & & & $\neg$ & -7 & \\
\hline & & $r$ & & & & & $r$ & $r$ & $r$ & & & & & $r$ & & & & & & & & 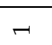 & -7 & \\
\hline & & - & & -1 & & & $r$ & - & -1 & & & & & -1 & & & & & & & & 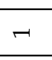 & -1 & \\
\hline-7 & $r$ & & - & & & & $r$ & & & - & & & - & & & & & & & & & $\neg$ & -7 & \\
\hline-7 & $r$ & - & - & $\neg$ & & & - & & & $r$ & & $\neg$ & & & & & & & & & & $\neg$ & -7 & \\
\hline & & & & -7 & & & & & & $r$ & & & & & - & & & & & & & - & $r$ & \\
\hline$r$ & $r$ & & - & & & & - & & & $r$ & & & & & 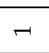 & & & & & & & $\neg$ & -7 & \\
\hline & & $r$ & & $r$ & & $r$ & $r$ & $\neg$ & -7 & & & & - & & & & & & & & & $r$ & -1 & \\
\hline 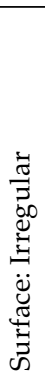 & 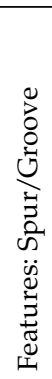 & 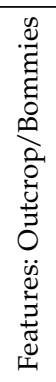 & 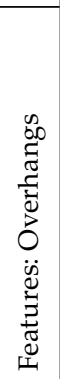 & 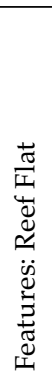 & 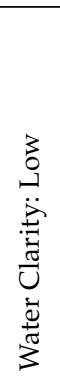 & 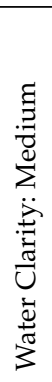 & 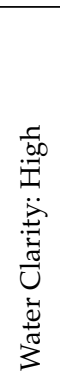 & 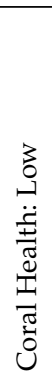 & 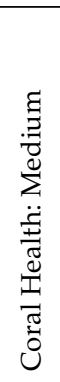 & 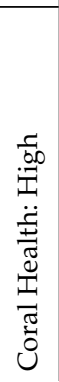 & 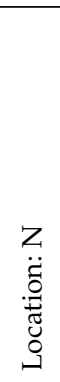 & 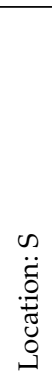 & 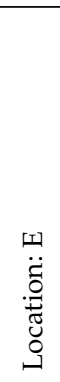 & 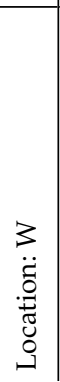 & 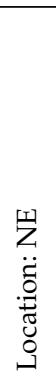 & 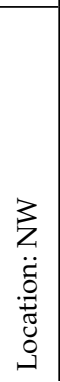 & 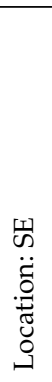 & 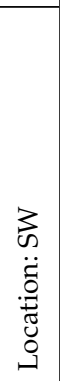 & 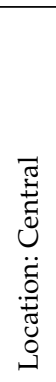 & 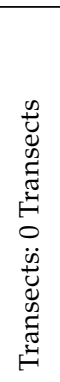 & 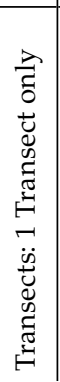 & 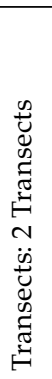 & 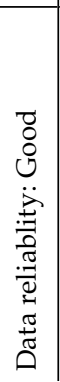 & 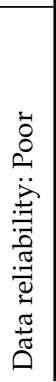 \\
\hline
\end{tabular}


范

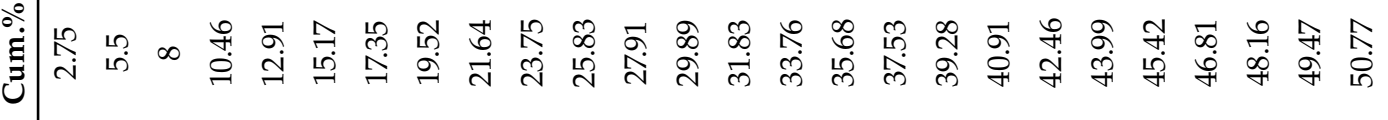

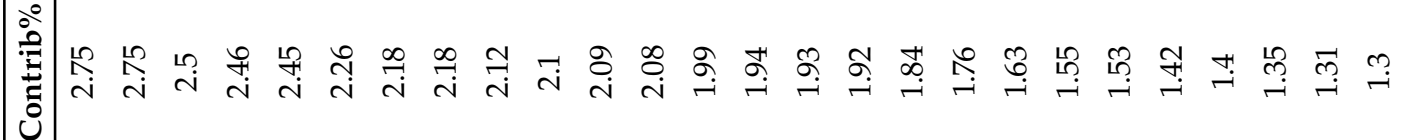

की

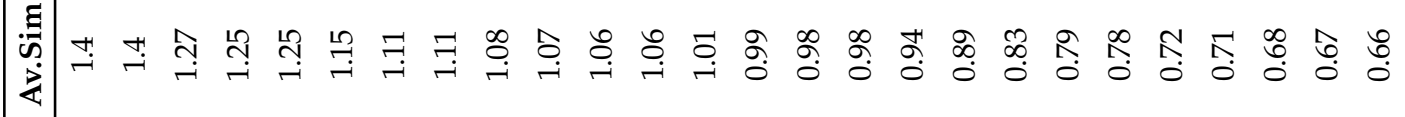

实芯

常

(5)

急

寻

苂.

을 을

否.

로름

पे क力 के

$\stackrel{0}{0}$

률

पै

त.

क्ष

高: 尝

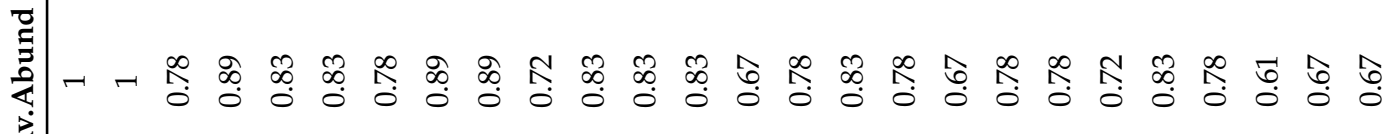

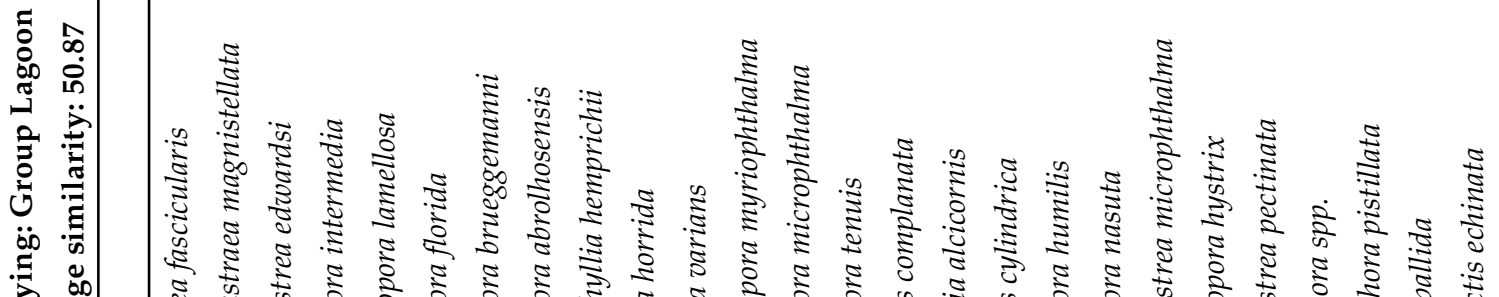

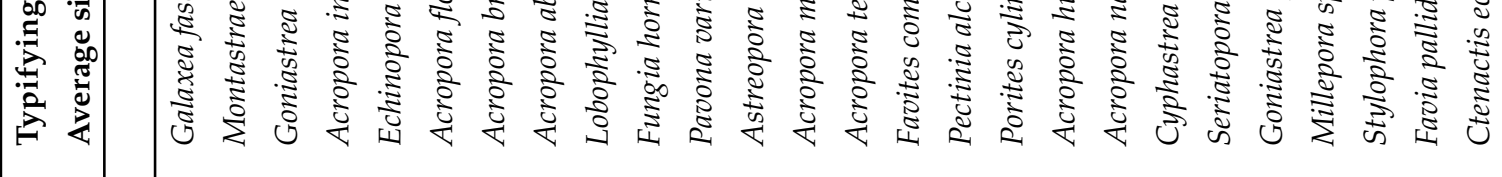

雚 


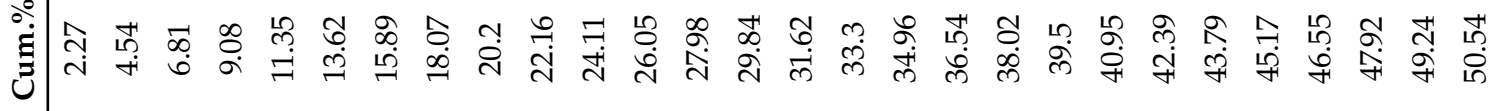

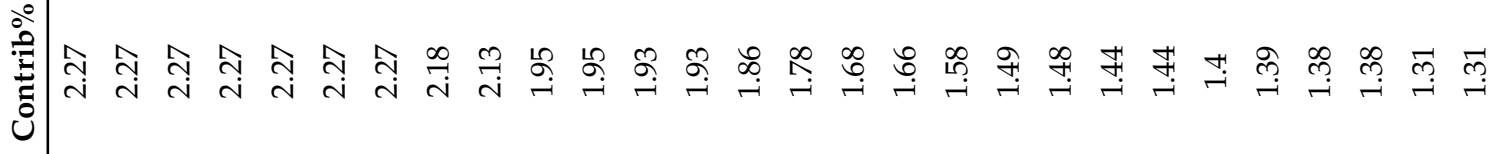

W્ઞ

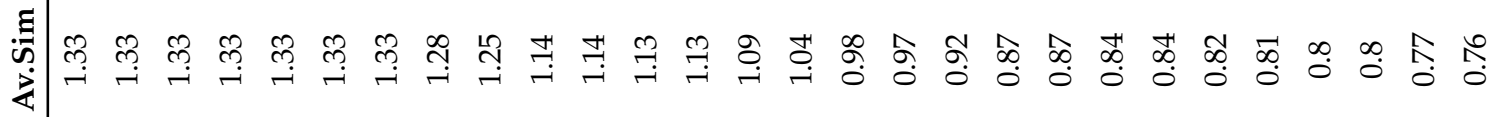

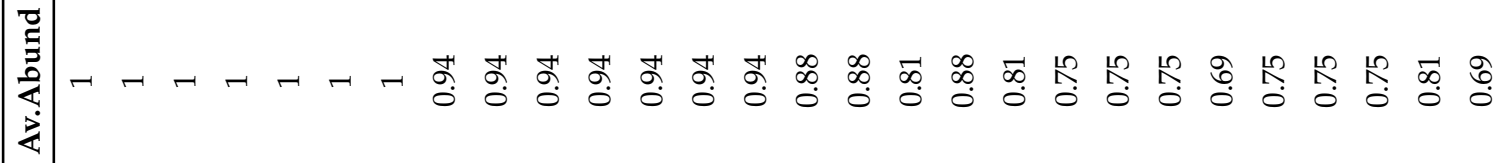

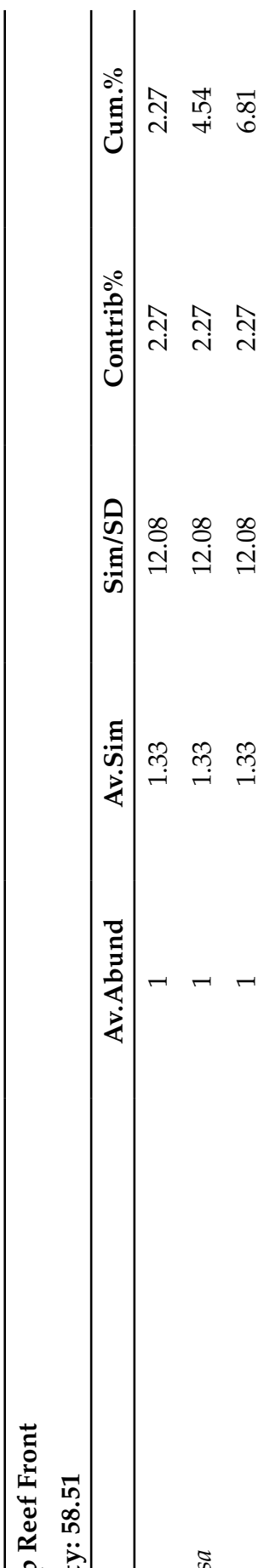




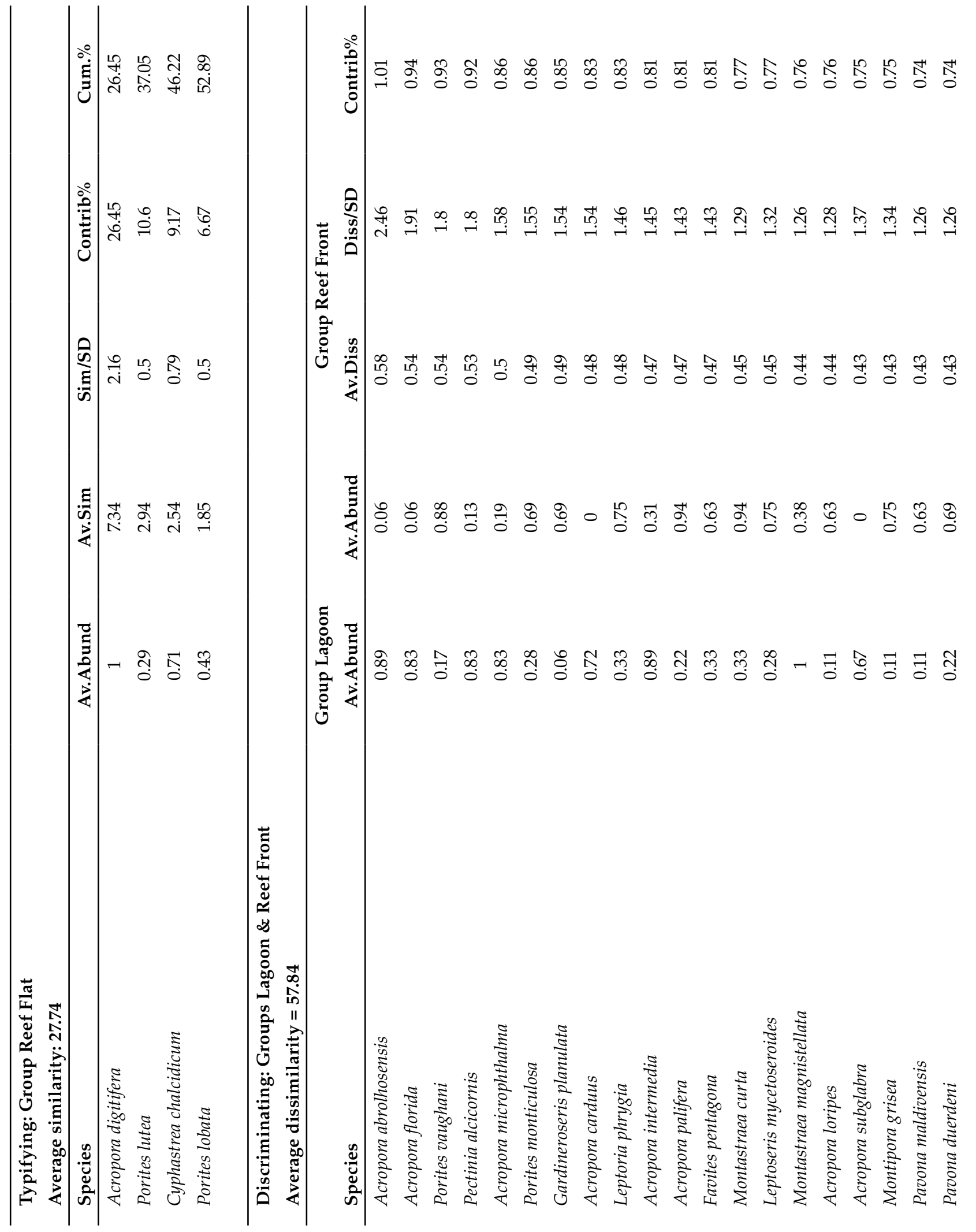




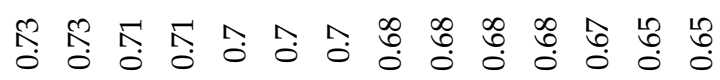

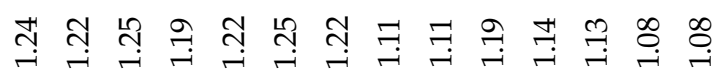

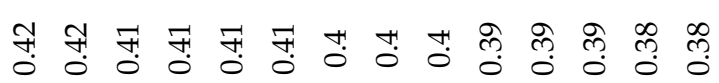

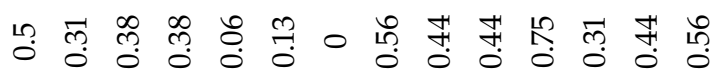

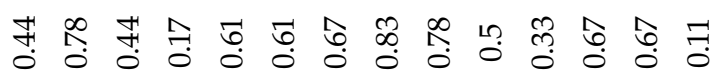
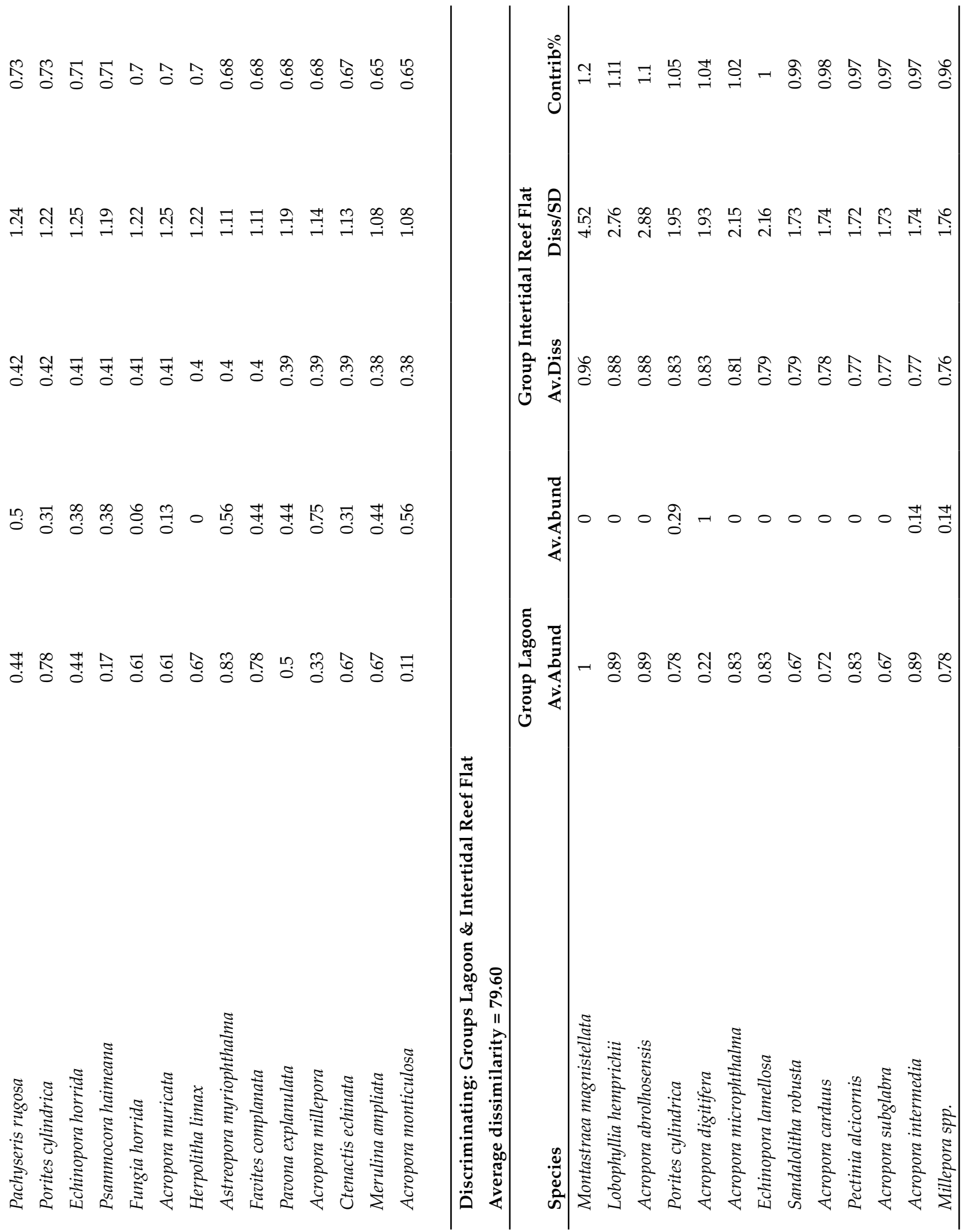

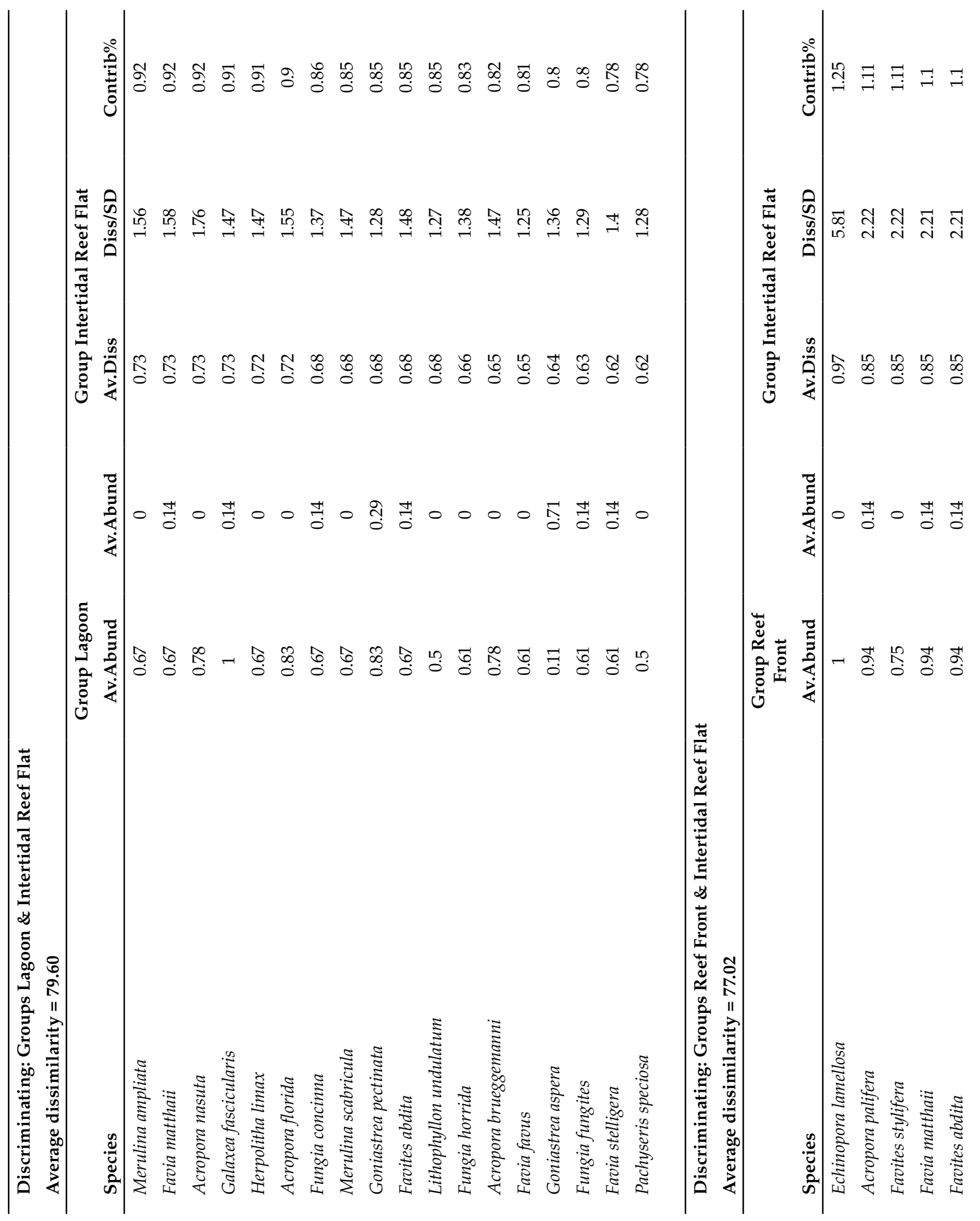
啰 穴

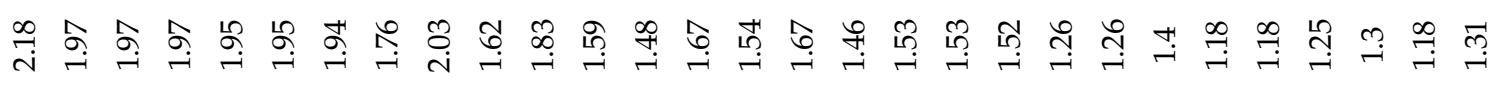

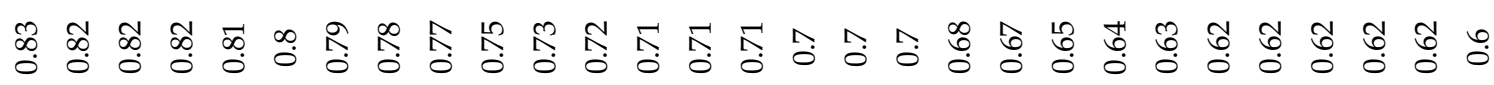

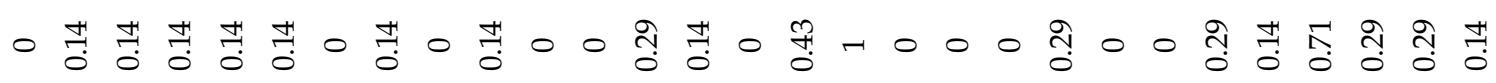

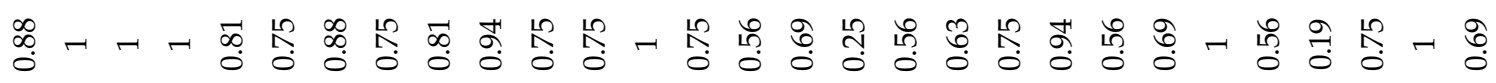

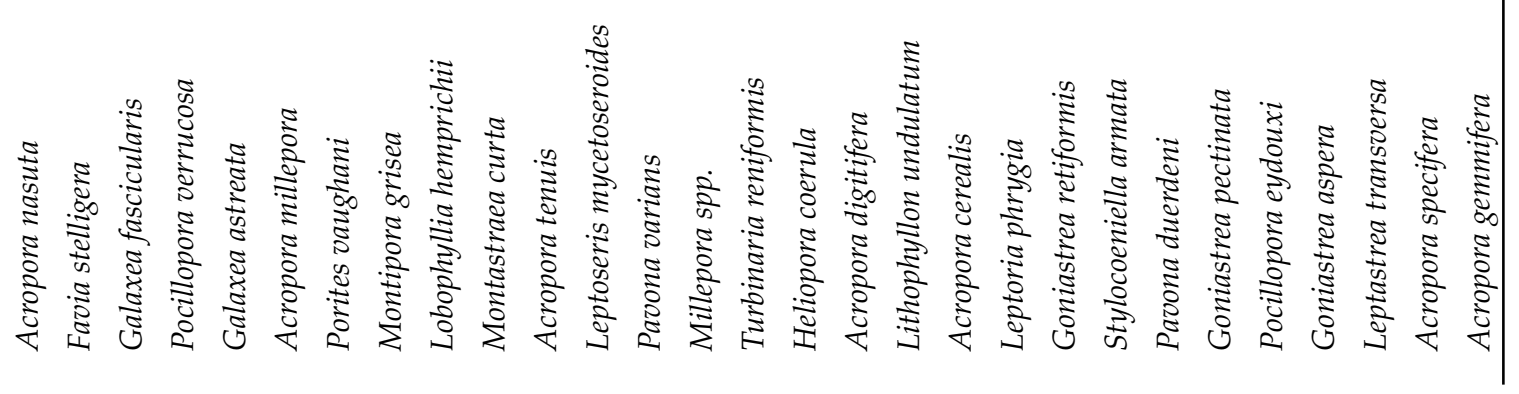


Table 6 Similarity Percentages of functional groups (SIMPER).

Major functional groups typifying and discriminating between lagoon and reef front habitats, listed in decreasing order. Two-way analysis examining habitat type groups (across all reef system groups).

\begin{tabular}{|c|c|c|c|c|c|}
\hline \multicolumn{6}{|l|}{$\begin{array}{l}\text { Typifying: Group Lagoon } \\
\text { Average similarity: } 62.50\end{array}$} \\
\hline & Av.Abund & Av.Sim & Sim/SD & Contrib\% & Cum.\% \\
\hline Rubble & 0.43 & 32.78 & 2.13 & 52.46 & 52.46 \\
\hline Branching Acropora & 0.12 & 11.42 & 1.53 & 18.28 & 70.73 \\
\hline Sand & 0.11 & 8.12 & 1.59 & 12.99 & 83.73 \\
\hline Rock & 0.2 & 7.47 & 0.66 & 11.95 & 95.68 \\
\hline Tabulate Acropora & 0.02 & 1.04 & 0.79 & 1.67 & 97.34 \\
\hline Massive Non-Acropora & 0.04 & 0.71 & 0.44 & 1.13 & 98.48 \\
\hline Soft Coral & 0.01 & 0.34 & 0.29 & 0.55 & 99.03 \\
\hline Digitate Acropora & 0.02 & 0.31 & 0.54 & 0.5 & 99.53 \\
\hline Macroalgae & 0 & 0.12 & 0.4 & 0.2 & 99.73 \\
\hline Mushroom coral & 0.01 & 0.09 & 0.29 & 0.14 & 99.86 \\
\hline Sub-massive Non-Acropora & 0.01 & 0.05 & 0.45 & 0.08 & 99.95 \\
\hline Foliaceous Non-Acropora & 0 & 0.02 & 0.22 & 0.03 & 99.97 \\
\hline Encrusting Non-Acropora & 0 & 0.02 & 0.16 & 0.03 & 100 \\
\hline \multicolumn{6}{|l|}{ Typifying: Group Reef Front } \\
\hline \multicolumn{6}{|l|}{ Average similarity: 68.66} \\
\hline & Av.Abund & Av.Sim & Sim/SD & Contrib\% & Cum.\% \\
\hline Rock & 0.61 & 50.79 & 3.53 & 73.97 & 73.97 \\
\hline Encrusting Non-Acropora & 0.1 & 6.63 & 1.35 & 9.65 & 83.62 \\
\hline Massive Non-Acropora & 0.06 & 3.7 & 1.47 & 5.39 & 89.02 \\
\hline Digitate Acropora & 0.03 & 1.63 & 1.74 & 2.37 & 91.39 \\
\hline Soft Coral & 0.04 & 1.5 & 0.6 & 2.18 & 93.57 \\
\hline Sand & 0.03 & 1.21 & 0.7 & 1.77 & 95.34 \\
\hline Tabulate Acropora & 0.03 & 0.97 & 0.59 & 1.41 & 96.74 \\
\hline Rubble & 0.07 & 0.96 & 0.35 & 1.39 & 98.13 \\
\hline Sub-massive Non-Acropora & 0.02 & 0.91 & 1 & 1.32 & 99.45 \\
\hline Branching Acropora & 0.01 & 0.13 & 0.45 & 0.2 & 99.65 \\
\hline Macroalgae & 0.01 & 0.12 & 0.33 & 0.17 & 99.82 \\
\hline Foliaceous Non-Acropora & 0.01 & 0.09 & 0.24 & 0.13 & 99.95 \\
\hline Sponge & 0 & 0.03 & 0.25 & 0.05 & 100 \\
\hline Gorgonian Coral & 0 & 0 & 0 & 0 & 100 \\
\hline Mushroom coral & 0 & 0 & 0 & 0 & 100 \\
\hline
\end{tabular}

Descriminating: Groups Lagoon \& Reef Front

Average dissimilarity $=67.35$

\begin{tabular}{lcccccc}
\hline & $\begin{array}{c}\text { Group Lagoon } \\
\text { Av.Abund }\end{array}$ & Av.Abund & Av.Diss & $\begin{array}{c}\text { Group Reef Front } \\
\text { Diss/SD }\end{array}$ & Contrib\% & Cum.\% \\
\hline Rock & 0.2 & 0.61 & 21.27 & 1.82 & 31.58 & 31.58 \\
Rubble & 0.43 & 0.07 & 17.93 & 1.84 & 26.62 & 58.2 \\
Branching Acropora & 0.12 & 0.01 & 6.3 & 1.18 & 9.36 & 67.56 \\
Encrusting Non-Acropora & 0 & 0.1 & 6.29 & 1.18 & 9.33 & 76.9 \\
Sand & 0.11 & 0.03 & 5.46 & 1.38 & 8.11 & 85 \\
Massive Non-Acropora & 0.04 & 0.06 & 2.51 & 1.48 & 3.72 & 88.73 \\
Digitate Acropora & 0.02 & 0.03 & 1.97 & 0.84 & 2.93 & 91.66 \\
Soft Coral & 0.01 & 0.04 & 1.76 & 0.74 & 2.61 & 94.26 \\
Tabulate Acropora & 0.02 & 0.03 & 1.48 & 0.69 & 2.19 & 96.46 \\
Sub-massive Non-Acropora & 0.01 & 0.02 & 0.93 & 1.31 & 1.38 & 97.84 \\
Foliaceous Non-Acropora & 0 & 0.01 & 0.54 & 0.71 & 0.8 & 98.63 \\
Macroalgae & 0 & 0.01 & 0.43 & 0.65 & 0.64 & 99.28 \\
Mushroom coral & 0.01 & 0 & 0.26 & 0.61 & 0.38 & 99.66 \\
Sponge & 0 & 0 & 0.15 & 0.74 & 0.22 & 99.88 \\
Gorgonian Coral & 0 & 0 & 0.08 & 0.19 & 0.12 & 100 \\
\hline
\end{tabular}




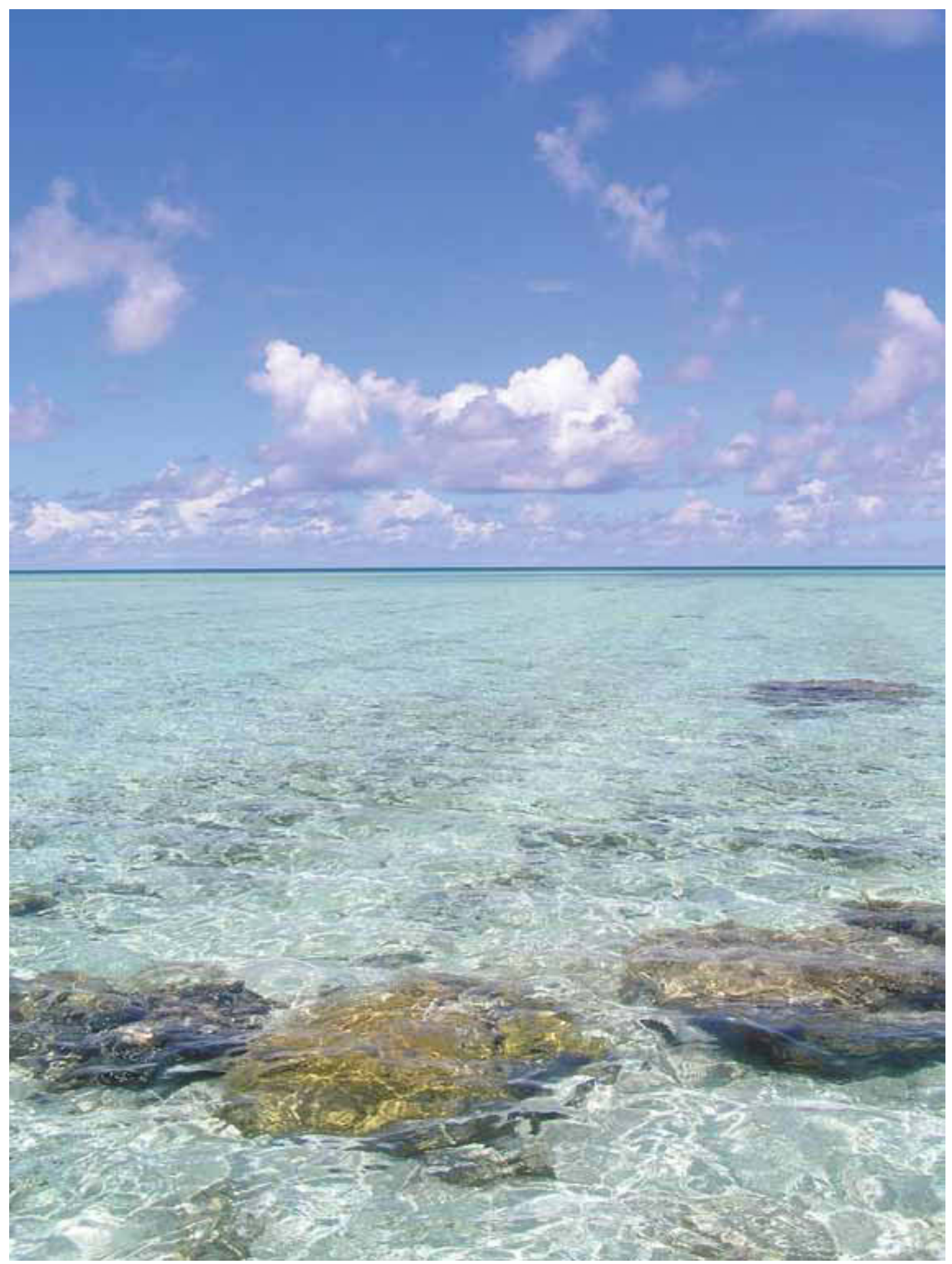

Above: South Scott Reef lagoon, back slope. (Photo: Clay Bryce) 


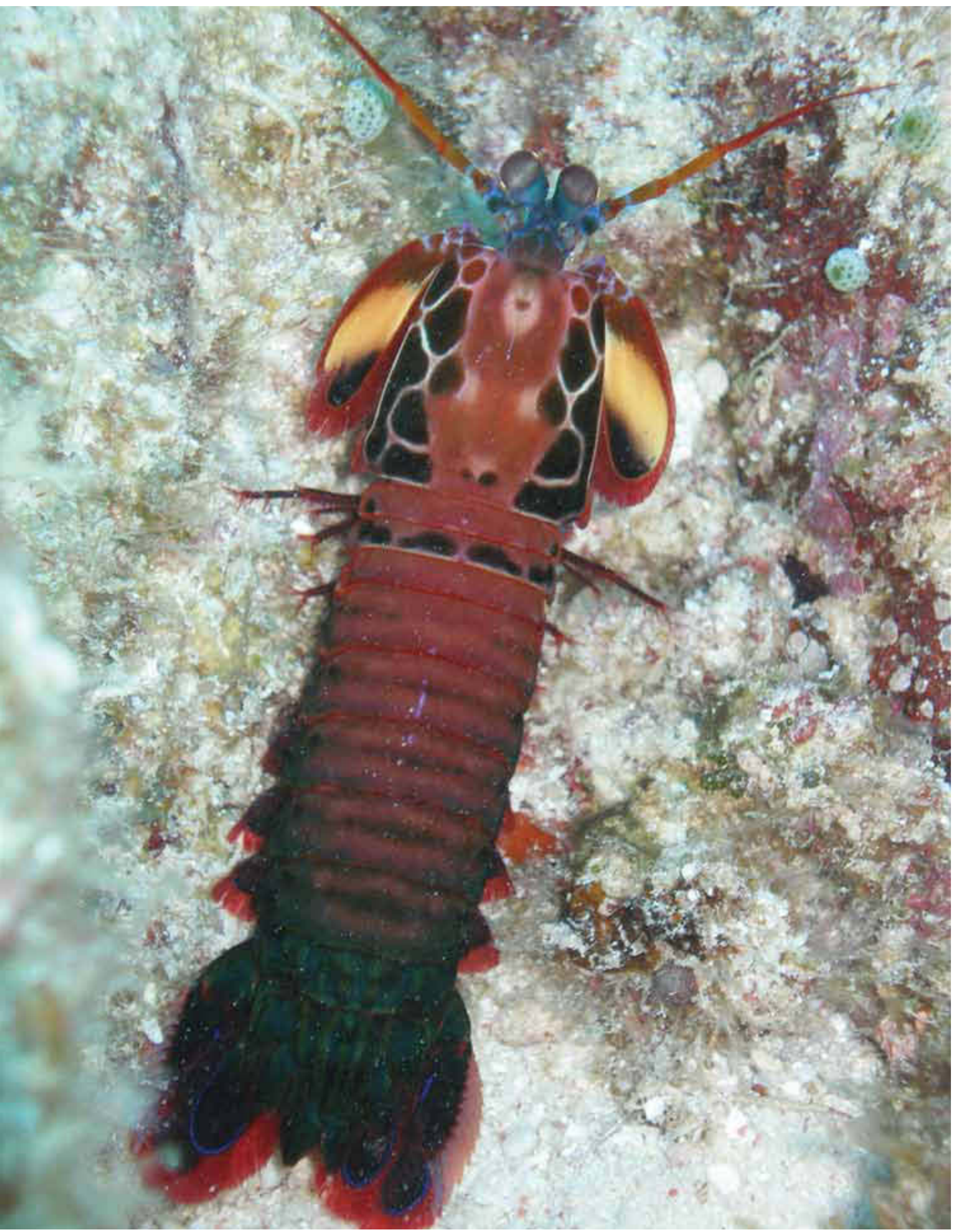

Above: Odontodactylus scyllarus (Linnaeus, 1758). The harlequin mantis shrimp. Photo: Glenn Moore) 